MARVIN MARCO CHAMBI PERALTA

USO DE UM LODO DE CROMO PROVENIENTE DA INDÚSTRIA DE CURTUME NA FABRICAÇÃO DE VIDROS SODO-CÁLCICOS 


\title{
USO DE UM LODO DE CROMO PROVENIENTE DA INDÚSTRIA DE CURTUME NA FABRICAÇÃO DE VIDROS SODO-CÁLCICOS
}

\author{
Tese apresentada à Escola \\ Politécnica da Universidade de São \\ Paulo para obtenção do título de \\ Doutor em Ciências \\ Área de concentração: \\ Engenharia Metalúrgica e de Materiais \\ Orientador: \\ Prof. Dr. Samuel Marcio Toffoli
}


Este exemplar foi revisado e corrigido em relação à versão original, sob responsabilidade única do autor e com a anuência de seu orientador.

São Paulo, de setembro de 2014.

Assinatura do autor

Assinatura do orientador

Catalogação-na-publicação

Chambi Peralta, Marvin Marco

Uso de um lodo de cromo proveniente da indústria de curtume na fabricação de vidros sodo-cálcicos / M.M. Chambi Peralta. -- versão corr. -- São Paulo, 2014.

$101 \mathrm{p}$.

Tese (Doutorado) - Escola Politécnica da Universidade de São Paulo. Departamento de Engenharia Metalúrgica e de Materiais.

1.Lodo 2.Cromo 3.Indústria do vidro 4.Vidro (Fabricação) I.Universidade de São Paulo. Escola Politécnica. Departamento de Engenharia Metalúrgica e de Materiais II.t. 
Quien vive de prisa no vive de veras, quien no echa raíces no puede dar frutos. (José Santos Chocano) 


\section{Agradecimentos}

Primeiramente agradeço a Deus por cada dia vivido e por ter me dado saúde e perseverança para a realização deste trabalho.

À minha família, sempre presente e principalmente aos meus pais, José e Glory, mesmo que distantes sempre pude encontrar neles, palavras de apoio e estimulo.

À minha noiva, Luciana, pelo amor, amizade e apoio incondicional, especialmente nos momentos em que nada parecia dar certo.

Ao Prof. Dr. Samuel Toffoli pela paciente orientação, confiança, amizade e apoio, sem os quais não seria possível a realização deste trabalho.

Aos professores e funcionários do Departamento de Metalúrgica e de Materiais da Universidade da Escola Politécnica da Universidade de São Paulo, pelos ensinamentos transmitidos, amizade e pelo apoio na elaboração desta tese.

Aos professores Dr. Shigueo Watanabe (Instituto de Física da USP), Dr. José Roberto Martinelli (IPEN), Dr. Glauco Vieira (Faculdade de Odontologia da USP) e Dr. Davinson Mariano da Silva (FATEC-SP), pela confiança e por permitir realizar testes e ensaios importantes para a conclusão deste trabalho nas dependências do seus respectivos laboratórios.

Aos professores Cyro Takano, Guilherme Lenz e Mauro Akerman pelas valiosas críticas e sugestões concedidas no exame de qualificação.

Ao Eng. César Figueiredo de Mello Barros da Associação dos Manufaturadores de Couros e Afins do Distrito Industrial de Franca (AMCOA), pelo apoio na coleta dos resíduos e pelas informações técnicas fornecidas.

Aos professores, técnicos e colegas do Laboratório de Sólidos Não-Metálicos Pérsio de Sousa Santos (LPSS), que me ajudaram em diversos momentos durante o tempo de realização deste trabalho, pelo dia-a-dia e pela amizade.

Aos meus amigos do "Iquiririm" por todo o tempo de convívio e amizade. Aos colegas de curso e amigos que fiz neste período, cada um deles sempre será uma lembrança boa da época de doutorado.

À Coordenação de Aperfeiçoamento de Pessoal de Nível Superior (CAPES) pela concessão da bolsa de doutorado.

Enfim, meus sinceros agradecimentos a todos os que contribuíram, direta ou indiretamente, para a realização deste trabalho. 


\section{Resumo}

A indústria de produção de couro gera uma grande quantidade de resíduos com características poluentes e de elevada periculosidade, entre os quais se destacam os resíduos curtidos (aparas, serragem e pó de couro curtido) e os lodos provenientes das estações de tratamento de efluentes (lodos de cromo, lodos primários e lodos secundários). Estes resíduos possuem uma considerável quantidade de compostos de $\mathrm{Cr}$ (III) na sua composição, os quais, sob condições oxidantes, podem transformar-se em $\mathrm{Cr}(\mathrm{VI})$, que é altamente tóxico para animais, plantas e seres humanos. No entanto, estes resíduos constituem uma potencial fonte alternativa de cromo (tradicional pigmento industrial) que poderia ser aproveitada pela indústria de vidros e de esmaltes. No presente trabalho foi realizado o estudo das propriedades físicas e químicas de um lodo de cromo proveniente do distrito industrial do município de Franca/SP, com o intuito de avaliar a viabilidade da utilização das cinzas da incineração deste resíduo como uma potencial fonte alternativa de cromo na fabricação de vidros sodo-cálcicos coloridos para embalagens. Fluorescência de Raios X (FRX), Difração de Raios X (DRX), análises termodiferencial (DTA) e termogravimétrica (TG/DTG), análise elementar, análise granulométrica, determinação de poder calorífico pelo método da bomba calorimétrica e Microscopia Eletrônica de Varredura (MEV) foram usados para determinar as características físicas e químicas do lodo de cromo. A incineração do resíduo foi realizada numa mufla elétrica a $800{ }^{\circ} \mathrm{C}$, utilizando um cadinho de alumina. A determinação da concentração de íons $\mathrm{Cr}(\mathrm{VI})$ presentes no lodo e nas cinzas foi realizada através do método colorimétrico utilizando difenilcarbazida. Vidros sodo-cálcicos contendo as cinzas da incineração do lodo de cromo foram preparados por meio da fusão das matérias-primas industriais (areia, barrilha e calcário) em cadinhos de alumina a $1500^{\circ} \mathrm{C}$ por $1 \mathrm{~h}$, sob condições similares às utilizadas no processo industrial de produção de vidros comerciais de coloração verde (composição, adição de ferro e condições redutoras). Para fins de comparação, foram preparadas também amostras de vidros contendo cromita (tradicional fonte industrial de cromo utilizada pela indústria de vidros) sob condições semelhantes. As amostras de vidros foram caracterizadas em termos de composição química por FRX, MEV, DRX, coordenadas colorimétricas (sistema CIEL*a*b*) e absorção óptica. Os resultados de FRX mostraram que as cinzas apresentam um teor de cromo de aproximadamente $47 \%$ em massa de $\mathrm{Cr}_{2} \mathrm{O}_{3}$, valor não muito distante do teor de cromo observado na composição da cromita (cerca de $43 \%$ em massa de $\mathrm{Cr}_{2} \mathrm{O}_{3}$ ). Os vidros preparados utilizando cromita e as cinzas da incineração de lodo de cromo apresentaram bandas de absorção óptica semelhantes no intervalo analisado $(200-3300 \mathrm{~nm})$, sem a presença aparente da banda de absorção óptica entorno de $370 \mathrm{~nm}$, característica do íon $\mathrm{Cr}^{6+}$. Estes resultados sugerem que sob condições adequadas de incineração do lodo, bem como formulação e fusão do vidro, é possível utilizar-se as cinzas obtidas como fonte alternativa de cromo para a fabricação de vidros coloridos do sistema soda-cal-sílica.

Palavras-chave: Indústria de curtume. Resíduos sólidos. Lodo de cromo. Cromo. Incineração. Cinzas. Vidro sodo-cálcico. 


\section{Abstract}

Leather production industry generates large quantities of solid wastes with pollutant characteristics and hazardous conditions, such as tanned wastes (Chrome shaving, chrome splits and buffing dust) and sludges from wastewater treatment process (Tannery sludge, primary and secondary sludge). These wastes containing $\mathrm{Cr}(\mathrm{III})$, which, under oxidizing conditions, can turn into $\mathrm{Cr}(\mathrm{VI})$, an extremely toxic and cancerigenous form of the element. However, these wastes are a potential source of chromium (traditional industrial pigment) which could be used by the glass and ceramic enamels industries. In the present work was studied the physical and chemical properties of a tannery sludge from the industrial district of the city of Franca, São Paulo State, Brazil, in order to evaluate the feasibility of using the ashes from incineration of this waste as a potential alternative source of chromium for the manufacturing of soda-lime glasses. X-Ray Fluorescence (XRF), Xray Diffraction (XRD), Differential Thermal Analysis (DTA), Thermogravimetric Analysis (TG/DTG), elemental analysis, granulometric analysis, determination of calorific value by the bomb calorimeter method and Scanning Electron Microscopy (SEM) were used to determine the physical and chemical characteristics of tannery sludge. The tannery sludge incineration was performed using an alumina crucible in a electric oven at $800^{\circ} \mathrm{C}$. Colorimetric method using diphenylcarbazide were conducted to determinate the $\mathrm{Cr}(\mathrm{VI})$ concentration in the waste and the ashes from incineration. Soda-lime glass containing the ashes from incineration of tannery sludge was prepared by melting of industrial raw materials (sand, soda ash and limestone), in alumina crucibles at $1500{ }^{\circ} \mathrm{C}$ for 1 hour, under similar conditions to those used in the industrial production process of commercial green container glasses (composition, addition of iron and reducing conditions). For comparison purposes, glasses containing chromite (traditional industrial source of chromium used by the glass industry) were also prepared under similar conditions. The glass samples were characterized in terms of chemical composition by XRF, MEV, DRX, color (CIEL*a* $\mathrm{b}^{*}$ system) and optical absorption. The FRX results revealed that the ashes are composed by about $47 \mathrm{wt} \% \mathrm{Cr}_{2} \mathrm{O}_{3}$. This amount is not so far from the chromium content observed in the composition of chromite (about $43 \mathrm{wt} \% \mathrm{Cr}_{2} \mathrm{O}_{3}$ ). The glasses containing chromite and the ashes from the incineration of the tannery sludge exhibited approximately similar optical absorption bands in the analyzed range (200-3300 nm), without the presence of optical absorption band around $370 \mathrm{~nm}$, characteristic of $\mathrm{Cr}^{6+}$. These results suggests that under appropriate incineration conditions of the sludge, as well as formulation and melting of glass, is possible use the chromium-rich ashes from incineration of tannery sludge as an alternative source of chromium for the manufacturing of colored glasses of the soda-lime-silica system.

keywords: Tannery industry. Solid wastes. Tannery sludge. Chromium. Incineration. Ashes. Sodo-lime glass. 


\section{Sumário}

\section{Lista de Figuras}

\section{Lista de Tabelas}

\section{Lista de Abreviaturas e Siglas}

\section{Lista de Fórmulas}

1 Introdução 1

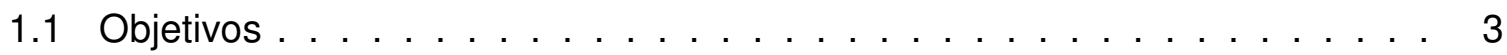

1.1 .1 Objetivo geral . . . . . . . . . . . . . . . 3

1.1 .2 Objetivos específicos . . . . . . . . . . . . . 3

2 Revisão da literatura 4

2.1 ovidro . . . . . . . . . . . . . . . . . . . . . . . . 4

2.1 .1 Definição de vidro . . . . . . . . . . . . . . . . . 5

2.1 .2 Transição vítrea . . . . . . . . . . . . . . . . . . . . . . 6

2.1 .3 Estrutura do vidro . . . . . . . . . . . . . . . . . . . . . . . . . 7

2.1 .4 Os vidros sodo-cálcicos . . . . . . . . . . . . . . . . . . . . . . . . . . 8

2.1 .5 Vidro de embalagem $\ldots \ldots \ldots . \ldots . \ldots 9$

2.2 Acor . . . . . . . . . . . . . . . . . . 10

2.2.1 Medição da cor . . . . . . . . . . . . . . . . . . . . . . . . . 12

2.2.2 As causas da cor . . . . . . . . . . . . . . . . . . . . . 14

2.2 .3 A cor nos vidros . . . . . . . . . . . . . . . . . . 15 
2.2.4 Vidros verdes de embalagem . . . . . . . . . . . . . . . . . 17

2.3 Reações de óxido-redução nos vidros . . . . . . . . . . . . . . . . . . . . . 19

2.3.1 Influência da pressão parcial de oxigênio . . . . . . . . . . . . . 20

2.3.2 Influência da composição do vidro . . . . . . . . . . . . . . . . . 20

2.3.3 Interação entre dois óxidos redox no vidro . . . . . . . . . . . . . . 21

2.3.4 Ajuste e controle do estado redox . . . . . . . . . . . . . . . 23

2.4 Cromo . . . . . . . . . . . . . . . . . . . . 25

2.4.1 Produção no Brasil e no mundo . . . . . . . . . . . . . . . . . . 25

2.4 .2 Usos e funções . . . . . . . . . . . . . . . . . . . 26

2.4 .3 O cromo na indústria de couro . . . . . . . . . . . . . . 27

2.4 .4 Toxicologia do cromo . . . . . . . . . . . . . . . . 28

2.5 Indústria de couro . . . . . . . . . . . . . . . . . . 31

2.6 Processo de produção de couro . . . . . . . . . . . . . . . . . . 32

2.6 .1 Ribeira . . . . . . . . . . . . . . . . . 33

2.6 .2 Curtimento . . . . . . . . . . . . . . . . . 33

2.6 .3 Acabamento . . . . . . . . . . . . . . . . . . . 34

2.7 Tipos de curtume $\ldots \ldots \ldots$. . . . . . . . . . . . . . . . . . . . . . . . . . . .

2.7.1 Curtume produtor de "wet-blue" . . . . . . . . . . . . . . . . 34

2.7.2 Curtume produtor de semi-acabado . . . . . . . . . . . . . 34

2.7.3 Curtume de processamento completo . . . . . . . . . . . . . . . 34

2.7.4 Curtume de acabamento . . . . . . . . . . . . . . . . . 35

2.8 Resíduos sólidos gerados no processo de transformação do couro . . . . . 35

2.9 Destinação dos resíduos sólidos da indústria de couro: estado da arte . . . 39

3 Materiais e métodos 43

3.1 Síntese das atividades . . . . . . . . . . . . . . . . . . . 43

3.2 Materiais . . . . . . . . . . . . . . . . . . . . 44 
3.3 Métodos . . . . . . . . . . . . . . . . . . . . . . 45

3.3.1 Técnicas de caracterização . . . . . . . . . . . . . . . . . . . . . 45

3.3.2 Incineração do lodo de cromo . . . . . . . . . . . . . . . . . . 49

3.3.3 Preparação dos vidros . . . . . . . . . . . . . . . . . . . . 50

4 Resultados e discussão

4.1 Caracterização do lodo de curtimento . . . . . . . . . . . . . . . . . 53

4.1 .1 Composição química por FRX . . . . . . . . . . . . . . . . . . 53

4.1 .2 Composição mineralógica por DRX . . . . . . . . . . . . . . . 56

4.1.3 Análise térmica diferencial e termogravimétrica . . . . . . . . . . . 57

4.1.4 Determinação do teor de carbono, hidrogênio, nitrogênio e umidade . 59

4.1.5 Determinação da distribuição de tamanho de partícula . . . . . . . . 60

4.1.6 Determinação do poder calorífico e teor de cinzas . . . . . . . . . . 61

4.1.7 Determinação das espécies de cromo . . . . . . . . . . . . . . . . . 62

4.1.8 Microscopia Eletrônica de Varredura (MEV) e Espectroscopia de Energia Dispersiva (EDS) . . . . . . . . . . . . . . . . . . . 62

4.2 Caracterização das cinzas . . . . . . . . . . . . . . . . . . . . . . . 64

4.2 .1 Composição química por FRX . . . . . . . . . . . . . . . . . 64

4.2.2 Determinação da distribuição de tamanho de partícula . . . . . . . . 66

4.2.3 Determinação das espécies de cromo . . . . . . . . . . . . . . . 67

4.3 Caracterização dos vidros . . . . . . . . . . . . . . . . . . 68

4.3.1 Composição química por FRX . . . . . . . . . . . . . . . . . . 68

4.3.2 Microscopia Eletrônica de Varredura (MEV) e Espectroscopia de Energia Dispersiva (EDS) . . . . . . . . . . . . . . . . . . . . . 71

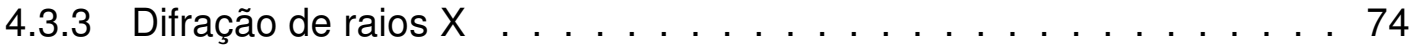

4.3.4 Determinação das coordenadas colorimétricas . . . . . . . . . . . . 75

4.3.5 Absorção óptica . . . . . . . . . . . . . . . . . . . . . . . 78 
5 Conclusões

6 Sugestões para trabalhos futuros $\quad 86$

Anexo A - Fluxogramas dos processos produtivos dos tipos de curtume

Referências

93 


\section{Lista de Figuras}

2.1 Variação do volume específico com a temperatura para um sólido cristalino e não cristalino. . . . . . . . . . . . . . . . . . . . . . . . . . . . . . . . 7

2.2 Produção de vidro no Brasil. . . . . . . . . . . . . . . . . . . . . . . 10

2.3 Espectro electromagnético e região do espectro visível. . . . . . . . . . . . . 11

2.4 Comprimentos de onda para as faixas espectrais das cores e seus valores correspondentes em Hertz e electrons volts. . . . . . . . . . . . . . . . . 12

2.5 Sistema de coordenadas CIELAB . . . . . . . . . . . . . . . . . 13

2.6 Espectros de absorção óptica de vidros silicatos coloridos com cromo (a) e ferro (b) em diferentes estados de valência. . . . . . . . . . . . . . . . . . . 18

2.7 Espectros de transmissão óptica dos vidros de embalagem verde (1) e âmbar (2). . . . . . . . . . . . . . . . . . . . . . . . . . . . . . . . 19

2.8 Variação da relações da forma oxidada e forma reduzida de distintos íons em função do $\log p_{O_{2}} \ldots \ldots$. . . . . . . . . . . . . . . . . . . . 20

2.9 Variação da proporção de íons $\mathrm{Fe}^{3+}$ em vidros do sistema $\mathrm{R}_{2} \mathrm{O}-\mathrm{SiO}_{2}$ en função da porcentagem molar de alcalinos. . . . . . . . . . . . . . . . . . . 21

2.10 Diagrama de Ellingham para alguns óxidos de interesse para a tecnologia de vidros. . . . . . . . . . . . . . . . . . . . . . . 22

2.11 Diagrama de Ellingham do $\mathrm{FeO}$ e $\mathrm{Na}_{2} \mathrm{O}$ num vidro silicato. . . . . . . . . 23

2.12 Variação da cor em função da relação do estado de oxido-redução do ferro num vidro sodo-cálcico. . . . . . . . . . . . . . . . . . . . . . . . . 25

2.13 Diagrama do processo de beneficiamento do couro. . . . . . . . . . . . . . 32

2.14 Principais resíduos gerados em cada etapa do processo de beneficiamento do couro. . . . . . . . . . . . . . . . . . . . . . . . . . . . 36

2.15 Resíduos sólidos curtidos gerados pela indústria de couro. . . . . . . . . . 37 
2.16 Etapas do tratamento de efluentes na indústria de produção de couro e os resíduos gerados durante estas etapas. . . . . . . . . . . . . . . . . . . . 38

3.1 Esquema de atividades . . . . . . . . . . . . . . . . . . 43

3.2 Amostras de lodo de cromo ( $A, B$ e $C$ ) e o lodo primário-secundário (D) coletadas no município de Franca, SP. . . . . . . . . . . . . . . . . . . . . . 44

3.3 Lodo de cromo após precipitação e secagem mecânica. . . . . . . . . . . . . 45

3.4 Lodo de cromo após moagem, homogeneização e quarteamento. . . . . . . . 49

3.5 Lodo de cromo (A), cadinho de alumina e lodo incinerado a $800{ }^{\circ} \mathrm{C}(\mathrm{B}) \ldots . .50$

3.6 Fotografia de uma amostra de vidro dentro do cadinho de alumina $(A)$ e amostra retirada do cadinho e cortada (B e C). . . . . . . . . . . . . . . . 52

4.1 Padrões de difração de raios $X$ do lodo de cromo: como recebido e incinerado a várias temperaturas por $1 \mathrm{~h}$. (G) $\mathrm{CaSO}_{4} \cdot 2 \mathrm{H}_{2} \mathrm{O},(\mathrm{C}) \mathrm{Cr}_{2} \mathrm{O}_{3}$ e

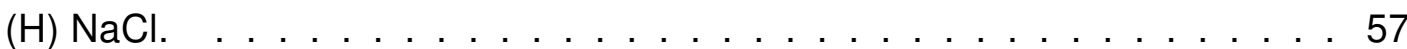

4.2 Curva de análise térmica diferencial do lodo de cromo. . . . . . . . . . . . 58

4.3 Curvas de análise termogravimétrica e diferencial termogravimétrica do lodo de cromo. . . . . . . . . . . . . . . . . . . . . . . . . . . 58

4.4 Distribuição de tamanho de partícula das matérias-primas utilizadas para a fabricação dos vidros. . . . . . . . . . . . . . . . . . . . . . . . . . . . . . . 60

4.5 Distribuição de tamanho de partícula do lodo de cromo e da cromita. . . . . 60

4.6 Micrografia e microanálise por EDS do lodo de cromo. . . . . . . . . . . . . 63

4.7 Micrografias do lodo indicando as áreas microanalisadas por EDS. . . . . . . 63

4.8 Comparação das distribuições granulométricas das cinzas provenientes da incineração com o lodo de cromo e a cromita. . . . . . . . . . . . . . . . . . 67

4.9 Matéria-prima residual presente na superfície de algumas amostras dos vidros preparados. . . . . . . . . . . . . . . . . . . . . . . . . 69

4.10 Amostras dos vidros sodo-cálcicos preparados utilizando cromita, cinzas da incineração do lodo de cromo e hematita. . . . . . . . . . . . . . . . . 71

4.11 Micrografias dos vidros sodo-cálcicos preparados: material infundido e microbolhas. . . . . . . . . . . . . . . . . . . . . . . 72 
4.12 Micrografias e microanálise por EDS dos vidros sodo-cálcicos preparados: material infundido localizado na superfície de algumas amostras. . . . . . . 73

4.13 Padrões de difração de raios X dos vidros preparados. . . . . . . . . . . . 75

4.14 Coordenadas colorimétricas no sistema CIE L*a*b* obtidas por refletância dos vidros comerciais e vidros preparados sob condições oxidantes e redutoras. . . . . . . . . . . . . . . . . . . 76

4.15 Coordenadas colorimétricas no sistema CIE L*a*b* obtidas por transmitância dos vidros comerciais e vidros preparados sob condições oxidantes e redutoras. . . . . . . . . . . . . . . . . . . 77

4.16 Amostras dos vidros de embalagem comerciais utilizados para armazenar refrigerantes, cervejas e vinhos.

4.17 Curvas dos coeficientes de absorção óptica dos vidros de embalagem comerciais. (A) Bandas de absorção na região do ultravioleta, visível e infravermelho próximo, (B) Região do ultravioleta-visível. . . . . . . . . . . . . 79

4.18 Curvas dos coeficientes de absorção óptica dos vidros preparados utizando cromita e cinzas da incineração do lodo de cromo . . . . . . . . . . . . . . . . . 81

4.19 Curvas dos coeficientes de absorção óptica dos vidros preparados usando cromita e cinzas da incineração de lodo de cromo, ambos com adição de hematita. . . . . . . . . . . . . . . . . . . . . 82

4.20 Curvas dos coeficientes de absorção óptica dos vidros de embalagem comerciais e dos vidros preparados usando cromita e cinzas com a adição de hematita. . . . . . . . . . . . . . . . . . . 83

A.1 Diagrama do processo de beneficiamento de um curtume produtor de "wetblue" . . . . . . . . . . . . . . . . . . . . . 88

A.2 Diagrama do processo de beneficiamento de um curtume produtor de semiacabado

A.3 Diagrama do processo de beneficiamento de um curtume de processamento completo. . . . . . . . . . . . . . . . . . . . . . . . . . . 9 90

A.4 Diagrama do processo de beneficiamento de um curtume de acabamento a partir de "wet-blue" . . . . . . . . . . . . . . . . . . . . . . . . . . . 9 
A.5 Diagrama do processo de beneficiamento de um curtume de acabamento a partir de semi-acabado. . . . . . . . . . . . . . . . . . . 992 


\section{Lista de Tabelas}

2.1 Principais famílias de vidros. . . . . . . . . . . . . . . . . . . . . 5

2.2 Classificação dos vidros de acordo com os principais segmentos da indústria de vidro. . . . . . . . . . . . . . . . . . . . . . . . . 5 5

2.3 Classificação dos óxidos segundo Zachariasen. . . . . . . . . . . . . . . . . . 8

2.4 Composições químicas dos vidros sodo-cálcicos comerciais. . . . . . . . . . 9

2.5 As quinze causas da cor e alguns exemplos. . . . . . . . . . . . . . . . . . 14

2.6 Compostos utilizados para produzir cor em vidros, vidrados e esmaltes. . . 15

2.7 Cores em vidros sodo-cálcicos e outros vidros. . . . . . . . . . . . . . . 16

2.8 Cores correspondentes à posição do íon colorante na rede do vidro. . . . . 17

2.9 Serie de óxido-redução dos íons metálicos . . . . . . . . . . . . . . . . 21

2.10 Número redox de alguns agentes redutores e oxidantes usados na fabricação de vidros. . . . . . . . . . . . . . . . . . . . . . . . . . . . . . . . 24

2.11 Reservas e principais produtores de cromita no mundo no ano de 2012 . . 26

2.12 Limites de referência para compostos de $\mathrm{Cr}(\mathrm{III})$ e $\mathrm{Cr}(\mathrm{VI})$, estabelecidos pela U.S. EPA. . . . . . . . . . . . . . . . . . . . . . . . . . . . . 30

3.1 Composições nominais das amostras de vidros. . . . . . . . . . . . . . . . 51

3.2 Matérias-primas utilizadas na formulação dos vidros. . . . . . . . . . . . . . 51

4.1 Composição química dos lodos de cromo e lodo primário-secundário. . . . . 54

4.2 Composição química de lodos de cromo provenientes do tratamento de efluentes da indústria de curtume estudados por outros autores. . . . . . . . 55

4.3 Composição química das matérias-primas utilizadas para a preparação dos vidros sodo-cálcicos. . . . . . . . . . . . . . . . . . . . 56

4.4 Composição elementar de $\mathrm{C}, \mathrm{H}, \mathrm{N}, \mathrm{S}$ e teor de umidade do lodo de cromo estudado comparado aos resultados reportados por outros autores. . . . . 59 
4.5 Valores de PCS, PCl e teor de cinza do lodo de cromo. . . . . . . . . . . 61

4.6 Concentração de cromo total e cromo hexavalente no lodo de cromo. . . . . 62

4.7 Composição química por FRX e microanálise química por EDS do lodo de cromo. . . . . . . . . . . . . . . . . . . . . . 664

4.8 Composição química por FRX da cromita e das cinzas provenientes da incineração do lodo de cromo. . . . . . . . . . . . . . . . . . . . . . . . 65

4.9 Composição química das cinzas resultantes da incineração a diferentes temperaturas de outros resíduos sólidos provenientes da indústria de fabricação de couro. . . . . . . . . . . . . . . . . . . . . . . . . . . . 666

4.10 Concentração de espécies de cromo das cinzas da incineração de lodo cromo e aparas de couro. . . . . . . . . . . . . . . . . . . . . . . . . 68

4.11 Composição química dos vidros sodo-cálcicos preparados utilizando cromita, cinzas da incineração do lodo de cromo e hematita. . . . . . . . . . . . 69

4.12 Composição química das amostras dos vidros de embalagem comerciais utilizados para armazenar cervejas e vinhos. . . . . . . . . . . . . . . . 70

4.13 Composição química por EDS dos vidros preparados. . . . . . . . . . . . . 74

4.14 Coordenadas colorimétricas no sistema CIE L*a*b* obtidas por transmitância e refletância dos vidros comerciais e experimentais. . . . . . . . . . . . 78 


\title{
Lista de Abreviaturas e Siglas
}

\author{
ABNT Associação Brasileira de Normas Técnicas \\ ABIVIDRO Associação Técnica Brasileira das Indústrias Automáticas de Vidro \\ AMCOA Associação dos Manufatores de Couros e Afins do Distrito Industrial \\ de Franca \\ ASTM Associação Americana de Ensaios e Materiais \\ CICB Centro das Indústrias de Curtumes do Brasil \\ CIE Comissão Internacional de lluminação \\ CQA Centro de Qualidade Analítica Ltda. \\ DRX Difração de Raios $X$ \\ DTA Análise Térmica Diferencial \\ DTG Análise Termogravimétrica Derivada \\ EDS Espectroscopia de Energia Dispersiva de Raios X \\ EPUSP Escola Politécnica da Universidade de São Paulo \\ ETEs Estações de Tratamento de Efluentes \\ FATEC-SP Faculdade de Tecnologia de São Paulo \\ FRX Fluorescência de Raios $X$ \\ IARC Agência Internacional para a Pesquisa do Câncer \\ ICP-AES Espectrometria de Emissão Atômica por Plasma Acoplado Indutivamente \\ IFUSP Instituto de Física da Universidade de São Paulo \\ IGC Instituto de Geociências \\ IQ Instituto de Química \\ ISO Organização Internacional de Normalização \\ IUPAC União Internacional de Química Pura e Aplicada \\ JCPDS Comitê de Junta de Padrões de Difração de Pós \\ LACIFID Laboratório de Cristais lônicos, Filmes Finos e Datação \\ LCT Laboratório de Caracterização Tecnológica \\ LDRX Laboratório de Difração de Raios $X$ \\ MEV Microscopia Eletrônica de Varredura
}


NRC Conselho Nacional de Pesquisa dos Estados Unidos

PCI Poder Calorífico Inferior

PCS Poder Calorífico Superior

PF Perda ao Fogo

PMI Departamento de Engenharia de Minas e Petróleo

PMT Departamento de Engenharia Metalúrgica e de Materiais

$\mathbf{p O}_{2} \quad$ Pressão Parcial de Oxigênio

RfC Concentração de Referência para Inalação

RfD Dose de Referência Oral

TG Análise Termogravimétrica

Tg Temperatura de Transição Vítrea

Tm Temperatura de Fusão

U.S. EPA Agência de Proteção Ambiental dos Estados Unidos

UFRGS Universidade Federal do Rio Grande do Sul

UNESCAP Comissão Econômica e Social para a Ásia e o Pacífico

UR Fator Unitário de Risco

USP Universidade de São Paulo

WDS Espectroscopia por Dispersão de Comprimento de Onda 


\section{Lista de Fórmulas}

\begin{tabular}{|c|c|}
\hline $\mathrm{CaCr}_{2} \mathrm{O}_{3}$ & Cromita de cálcio \\
\hline $\mathrm{CaCrO}_{4} \cdot 2 \mathrm{H}_{2} \mathrm{O}$ & Cromato de cálcio hidratado \\
\hline $\mathrm{CaSO}_{4} \cdot 2 \mathrm{H}_{2} \mathrm{O}$ & Sulfato de cálcio hidratado \\
\hline $\operatorname{Cr}(0)$ & Cromo Metálico \\
\hline $\operatorname{Cr}(I I)$ & Cromo bivalente \\
\hline $\operatorname{Cr}(I I I)$ & Cromo trivalente \\
\hline $\mathrm{Cr}(\mathrm{VI})$ & Cromo hexavalente \\
\hline $\operatorname{Cr}(\mathrm{V})$ & Cromo pentavalente \\
\hline $\mathrm{Cr}_{2} \mathrm{O}_{3}$ & Óxido de cromo (III) \\
\hline $\mathrm{CrO}_{3}$ & Óxido de cromo (VI) \\
\hline $\mathrm{Cr}(\mathrm{OH}) \mathrm{SO}_{4}$ & Sulfato básico de cromo \\
\hline $\mathrm{FeO}$ & Óxido de ferro (II) \\
\hline $\mathrm{Fe}_{2} \mathrm{O}_{3}$ & Óxido de ferro (III) \\
\hline $\mathrm{FeCr}_{2} \mathrm{O}_{4}$ & Cromita \\
\hline $\mathrm{H}_{2} \mathrm{CrO}_{3}$ & Ácido crômico \\
\hline $\mathrm{K}_{2} \mathrm{Cr}_{2} \mathrm{O}_{7}$ & Dicromato de potássio \\
\hline $\mathrm{K}_{2} \mathrm{CrO}_{4}$ & Cromato de potássio \\
\hline $\mathrm{Na}_{2} \mathrm{Cr}_{2} \mathrm{O}_{7}$ & Dicromato de sódio \\
\hline $\mathrm{Na}_{2} \mathrm{Cr}_{2} \mathrm{O}_{7} \cdot 2 \mathrm{H}_{2} \mathrm{O}$ & Dicromato de sódio hidratado \\
\hline $\mathrm{Na}_{2} \mathrm{CrO}_{4}$ & Cromato de sódio \\
\hline $\mathrm{Na}_{2} \mathrm{SO}_{4}$ & Sulfato de sódio \\
\hline $\mathrm{Na}_{4}\left(\mathrm{CrO}_{4}\right)\left(\mathrm{SO}_{4}\right)$ & Sulfato de sódio e óxido de cromo \\
\hline $\mathrm{NaCl}$ & Cloreto de sódio \\
\hline $\mathrm{PbCrO}_{2}$ & Crocoíta \\
\hline
\end{tabular}




\section{Introdução}

O Brasil é o segundo maior produtor de couro cru no mundo, superado apenas pela China e à frente da Índia e dos Estados Unidos. De acordo com dados do Centro das Indústrias de Curtumes do Brasil (CICB), a indústria de produção de couro é considerada um dos grandes motores da economia brasileira. Estima-se que a cadeia produtiva do couro que abrange os setores de curtumes, calçados, componentes, máquinas e equipamentos para artigos em couro, reúna ao redor de 10 mil indústrias, empregue mais de 500 mil pessoas e movimente aproximadamente US\$ 21 bilhões de dólares por ano (TAVARES, 2011).

O processo de transformação da pele em couro envolve uma ampla série de etapas físicas e químicas, nas quais são utilizadas grandes quantidades de água e diferentes reagentes químicos (PACHECO, 2005). Decorrentes destas etapas, grandes quantidades de resíduos sólidos, líquidos e gasosos são gerados diariamente. Dentre eles, destacamse os resíduos curtidos (aparas, serragem e pó de rebaixadeira de couro), lodos de cromo e os lodos primários e secundários, gerados nas Estações de Tratamento de Efluentes (ETEs). Estes resíduos possuem um considerável conteúdo de $\mathrm{Cr}$ (III), o qual, sob condições oxidantes, pode transformar-se em $\mathrm{Cr}(\mathrm{VI})$, que é altamente tóxico para plantas, animais e seres humanos (LANGARD; COSTA, 2007).

Durante os últimos anos, as indústrias brasileiras de produção de couro têm adotado varias práticas e tecnologias alternativas menos poluidoras, com o objetivo de otimizar o aproveitamento das matérias-primas, água, insumos químicos e minimizar a geração de resíduos. No entanto, a disposição das grandes quantidades de resíduos sólidos gerados no processo de transformação de pele em couro continua sendo um problema sério, principalmente devido à potencial periculosidade, reatividade e toxicidade destes resíduos.

No Brasil, a disposição final dos resíduos sólidos curtidos provenientes das indústrias de curtumes, classificados pela legislação brasileira (ABNT NBR 10004) como resíduos Classe I-perigosos, é realizada comumente em aterros sanitários classe I, já que esta representa uma alternativa relativamente barata (BLACKMAN, 2001). No entanto, devido à grande quantidade de resíduos sólidos gerados, aproximadamente $600 \mathrm{~kg}$ por tonelada de peles salgadas (PACHECO, 2005), os custos de transporte e disposição final destes 
resíduos resultam relativamente altos. Além disso, a disposição em aterros sanitários não é considerada uma alternativa de gestão sustentável de resíduos. Portanto, é imperativo buscar alternativas viáveis para reduzir, reutilizar, reciclar ou recuperar estes resíduos.

Nos últimos anos, a incineração tem sido reconhecida como um método altamente eficaz de redução de resíduos se conduzida sob condições adequadas. A incineração controlada destrói permanentemente compostos orgânicos tóxicos presentes nos resíduos sólidos, convertendo-os em moléculas estáveis, reduzindo o volume dos resíduos perigosos e produzindo um resíduo altamente concentrado contendo vários compostos inorgânicos (PICHTEL, 2005). Além disso, dependendo do Poder Calorífico Inferior (PCI) do resíduo, a incineração pode permitir a recuperação de calor, que por sua vez pode ser convertido em eletricidade, água quente, etc.

Devido ao considerável teor de cromo presente na composição dos resíduos sólidos provenientes das indústrias de curtume, vários estudos têm sido realizados com o propósito de recuperar e reutilizar este teor de cromo em diferentes aplicações, tais como, produção de sulfato básico de cromo, fabricação de ferroligas de alto carbono, e principalmente em aplicações cerâmicas (tijolos, porcelanato, refratários, pigmentos e esmaltes). A maior parte destes estudos tem-se focado principalmente na recuperação e reutilização do cromo proveniente das cinzas de incineração de aparas de couro. No entanto, recentemente, Abreu e Toffoli (2009) estudaram o uso das cinzas da incineração a $700{ }^{\circ} \mathrm{C}$ de um lodo de cromo como pigmento na fabricação de vidrados, por meio da fusão das cinzas em conjunto com um vidrado comercial, e mostraram que os vidrados preparados apresentam boas características visuais (tom de cor, textura e brilho) e boa estabilidade do cromo no vidro.

Baseados nos resultados de Abreu e Toffoli (2009), no presente trabalho foi realizado o estudo das propriedades físicas e químicas de um lodo de cromo proveniente do distrito industrial do município de Franca/SP, com o intuito de estudar a viabilidade da utilização das cinzas da incineração deste resíduo como uma fonte alternativa de cromo na fabricação de vidros sodo-cálcicos coloridos e desta maneira agregar valor econômico aos resíduos anteriormente não valorizados e eliminar este passivo ambiental. Para este propósito foram preparadas amostras de vidro sodo-cálcicos contendo as cinzas da incineração do lodo de cromo estudado por meio da fusão em escala de laboratório das matérias-primas industriais (areia, barrilha e calcário), sob condições similares às utilizadas no processo industrial de produção de vidros comerciais de coloração verde (composição, temperatura, adição de ferro e condições redutoras). 


\subsection{Objetivos}

\subsubsection{Objetivo geral}

O presente trabalho tem como principal objetivo estudar a viabilidade da utilização das cinzas da incineração de um lodo de cromo proveniente da indústria de curtume como uma potencial fonte alternativa de cromo, tradicional colorante industrial, na fabricação de vidros sodo-cálcicos coloridos para embalagens.

\subsubsection{Objetivos específicos}

- Determinar as características físicas e químicas de um lodo de cromo da indústria de curtume proveniente do pólo coureiro-calçadista da região de Franca/SP.

- Estabelecer um processo de incineração, em escala de laboratório, do lodo de cromo e caracterizar as cinzas geradas.

- Formular e preparar amostras de vidros sodo-cálcicos contendo as cinzas da incineração do lodo de cromo a partir da fusão de matérias-primas industriais (areia, barrilha e calcário) e sob condições semelhantes às utilizadas na fabricação de vidros sodo-cálcicos comerciais de coloração verde (condições redutoras e adição de ferro).

- Preparar amostras de vidros sodo-cálcicos adicionais contendo cromita (tradicional fonte de cromo utilizada pela indústria de fabricação de vidros) com composições e sob condições semelhantes às amostras de vidros preparadas utilizando as cinzas da incineração do lodo de cromo.

- Caracterizar todas as amostras de vidros sodo-cálcicos preparadas em termos de composição química, cor (sistema $\mathrm{CIEL}^{*} \mathrm{a}^{*} \mathrm{~b}^{*}$ ) e absorção óptica, e realizar comparações entre os resultados das análises das amostras preparadas utilizando cromita e os resultados das amostras preparadas utilizando cinzas da incineração do lodo de cromo. 


\section{Revisão da literatura}

Neste capítulo será apresentada uma breve abordagem sobre conceitos e dados relevantes relacionados aos materiais envolvidos neste trabalho. Primeiramente serão descritos conceitos gerais sobre os vidros, cor, causas da cor nos vidros e consequências dos estados de reação redox de equilíbrio para o vidro. Em seguida será realizada uma abordagem sobre o cromo, indústria do couro no Brasil, processo de produção de couro, resíduos gerados pela indústria de couro e as propriedades, usos e toxicologia do cromo. Já no último item será apresentado o estado da arte dos trabalhos relacionados com a pesquisa de métodos alternativos para reduzir, reutilizar, reciclar ou recuperar os resíduos sólidos gerados pela indústria de couro.

\subsection{0 vidro}

O vidro é um material utilizado pelo homem há milhares de anos. Acredita-se que a utilização de vidro tenha começado na idade da pedra (75000 A.C.) muito antes do homem dominar as técnicas de fabricação de vidro. Vidros naturais, formados pela fusão de rochas devido a fenômenos de alta temperatura, como erupções vulcânicas, relâmpagos ou ao impacto de meteoritos, eram utilizados pelos nossos ancestrais na elaboração de ferramentas de corte e pontas de setas (BOURHIS, 2007). Já os primeiros vidros produzidos pelo homem seriam fabricados milhares de anos mais tarde, por volta do 2000 A.C. no antigo Egito e na Mesopotâmia, com o propósito de produzir imitações de pedras preciosas e semipreciosas para a decoração de objetos (FORBES, 1997).

$\mathrm{Na}$ atualidade é possível encontrar peças de vidro em todos os lugares ao nosso redor, os vidros são utilizados numa ampla gama de aplicações, desde as mais simples, como copos e pratos, até as mais complexas e tecnológicas, como fibras ópticas e lentes de última geração (ABIVIDRO, 2009). A maior parte dos produtos comerciais de vidro produzidos no mundo é constituída por óxidos, em sua grande maioria baseados em sílica. Não obstante, existe uma grande variedade de tipos de vidros. A família dos vidros é enorme e encontra-se em contínuo crescimento. Ano após ano, novos tipos de vidros com propriedades inovadoras são descobertos. Na Tabela 2.1 são apresentadas algumas das principais famílias de vidros. 
Tabela 2.1 - Principais famílias de vidros.

\begin{tabular}{l}
\hline \multicolumn{1}{c}{ Principais famílias de vidros } \\
\hline Sílica amorfa \\
Vidros sodo-cálcicos \\
Vidros borossilicatos \\
Vidros de chumbo \\
Vidros aluminossilicatos \\
Outros vidros óxidos à base de sílica \\
Outros vidros óxidos não baseados em sílica \\
Vidros haletos \\
Semicondutores amorfos \\
Vidros calcogenetos e calcohaletos \\
Metais amorfos \\
Carbono vítreo \\
Vidros de oxihaletos, oxinitretos e oxicarbetos \\
\hline Fonte: Varshneya (1993)
\end{tabular}

A existência de uma ampla variedade de tipos de vidros assim como a rápida evolução dos métodos e processos de sua fabricação fazem da classificação dos vidros uma tarefa relativamente difícil. No entanto, a maior parte dos vidros podem ser classificada de maneira simples de acordo com o tipo de aplicação final a que se destinam. Na Tabela 2.2 é apresentada a classificação dos vidros de acordo com os principais segmentos da indústria de vidro.

Tabela 2.2 - Classificação dos vidros de acordo com os principais segmentos da indústria de vidro.

\begin{tabular}{lcccccc}
\hline \multicolumn{7}{c}{ Principais segmentos da indústria de vidro } \\
\hline Vidro & Vidro de & Vidro & Vidro & Vidro & Fibra de & Lã de \\
plano & embalagem & automotivo & artístico & ótico & vidro & vidro \\
\hline
\end{tabular}

Fonte: Axinte (2011)

\subsubsection{Definição de vidro}

Segundo o descrito pela Associação Americana de Ensaios e Materiais (ASTM), na norma ASTM C162, o vidro pode ser definido como "um produto inorgânico obtido a partir de um processo de fusão que é resfriado até atingir condições rígidas sem sofrer cristalização". No entanto esta definição não abrange a ampla variedade de vidros utilizados na atualidade. Embora os vidros sejam tradicionalmente formados a partir da fusão das matérias-primas e posterior resfriamento, a fusão não é uma condição essencial 
para a formação dos vidros. Na atualidade, vidros podem ser obtidos por outros métodos como a deposição de vapor químico, pelo método sol-gel e por irradiação de nêutrons em materiais cristalinos (SHELBY, 2005). Da mesma maneira a natureza química do material também não deve ser utilizada como um padrão para definir o vidro, mesmo que os vidros tradicionais sejam inorgânicos e não metálicos, na atualidade é utilizada uma ampla gama de vidros orgânicos e os vidros metálicos têm se tornado cada vez mais comuns com o passar dos anos (SHELBY, 2005).

Independentemente da natureza química do material e técnica utilizada, todos os vidros encontrados até o momento partilham duas características comuns. Primeiro, nenhum vidro tem estrutura atômica periódica de longo alcance. E ainda mais importante, todos os vidros exibem uma região de transição vítrea. Com base nestas duas características Shelby (2005) define o vidro como "um sólido amorfo, totalmente desprovido de uma estrutura atômica periódica de longo alcance e que exibe uma região de transição vítrea”.

\subsubsection{Transição vítrea}

A transição vítrea é um evento térmico que marca a passagem suave de um sólido não cristalino para um estado de líquido super-resfriado, quando este é aquecido, ou a passagem de um líquido super-resfriado, altamente viscoso, para um estado sólido não cristalino, quando este é resfriado (RAO, 2002). A passagem da região de transição vítrea é marcada por mudanças nas propriedades dos materiais não cristalinos, tais como a capacidade calorífica e o coeficiente de expansão térmica.

Na Figura 2.1 observa-se a variação do volume específico durante o resfriamento de um material no estado líquido. Dependendo das condições de resfriamento o material no estado líquido pode exibir dos comportamentos: se a taxa de resfriamento for suficientemente lenta para que o aparecimento de cristais ocorra facilmente, o volume diminuirá de maneira brusca na Temperatura de Fusão (Tm). Por outro lado, se a velocidade de resfriamento é suficientemente rápida para evitar a cristalização, o líquido permanecerá em equilíbrio metaestável até atingir a Temperatura de Transição Vítrea (Tg), quando os rearranjos estruturais passarão a ser cineticamente impedidos. Contudo, o volume abaixo da Tg continuará a diminuir, como consequência das menores amplitudes de vibração dos átomos em torno de suas posições fixas (ALVES; GIMENEZ; MAZALI, 2001; FURNISS; SEDDON, 2008). 
Figura 2.1 - Variação do volume específico com a temperatura para um sólido cristalino e não cristalino.

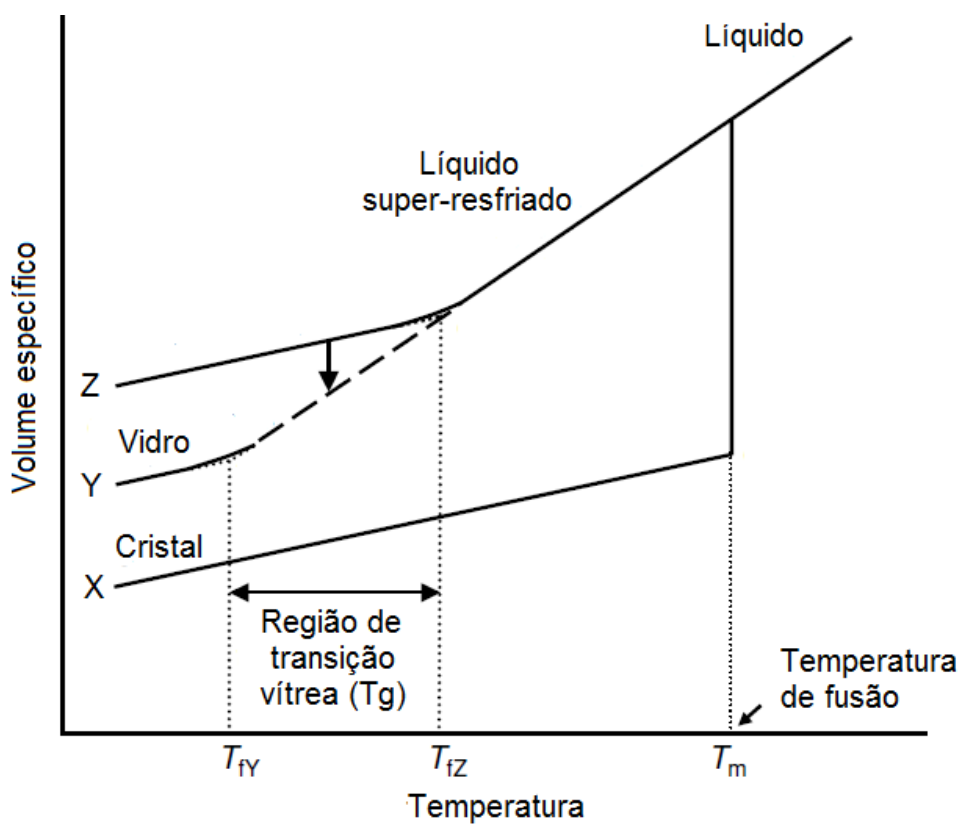

Fonte: Furniss e Seddon (2008)

\subsubsection{Estrutura do vidro}

Segundo a hipótese proposta por Zachariasen (1932) as propriedades mecânicas e a densidade do vidro são semelhantes às da forma cristalina correspondente. Consequentemente, pode-se assumir que os átomos no vidro são ligados por forças semelhantes às descritas nos cristais, e portanto, assim como nos cristais, os átomos no vidro devem formar longas redes tridimensionais. No entanto, estas redes não são simétricas e não apresentam periodicidade (como mostram os padrões de raios $\mathrm{X}$ ) como é sempre observado em um cristal. Com base nestes conceitos, ele propôs um conjunto de regras empíricas que um óxido deve satisfazer para ser um formador de vidro.

- Íons de oxigênio estão ligados a não mais de dois cátions (íons positivamente carregados, tais como sódio ou cálcio).

- O número de coordenação (número de ligações) dos cátions para os íons de oxigênio é baixo, geralmente quatro ou menos.

- Os poliedros de oxigênio (grupos de íons de oxigênio em torno de um cátion) não compartilham arestas nem faces, somente vértices.

- Os poliedros estão ligados formando uma rede tridimensional e pelo menos três vértices de cada poliedro devem ser compartilhados com outro poliedro. 
Os óxidos que atendem aos critérios para a formação de vidro são chamados formadores de rede. Aqueles que podem formar parte da rede mas, não podem formar uma rede sozinhos são chamados intermediários. Os outros íons presentes no vidro que não participam diretamente na rede e ocupam posições aleatórias nos espaços livres (buracos) são chamados de modificadores de rede e sua principal função é de contribuir com íons de oxigênio adicionais, que modificam a estrutura da rede (EPPLER, 2005). A Tabela 2.3 mostra os principais óxidos de importância prática.

Tabela 2.3 - Classificação dos óxidos segundo Zachariasen.

\begin{tabular}{ccc}
\hline Formadores de rede & Modificadores & Intermediários \\
\hline $\mathrm{SiO}_{2}$ & $\mathrm{Li}_{2} \mathrm{O}$ & $\mathrm{Al}_{2} \mathrm{O}_{3}$ \\
$\mathrm{GeO}_{2}$ & $\mathrm{Na}_{2} \mathrm{O}$ & $\mathrm{PbO}$ \\
$\mathrm{B}_{2} \mathrm{O}_{3}$ & $\mathrm{~K} O$ & $\mathrm{ZnO}$ \\
$\mathrm{P}_{2} \mathrm{O}_{5}$ & $\mathrm{CaO}$ & $\mathrm{CdO}$ \\
$\mathrm{As}_{2} \mathrm{O}_{3}$ & $\mathrm{BaO}$ & $\mathrm{TiO}_{2}$ \\
$\mathrm{As}_{2} \mathrm{O}_{5}$ & & \\
$\mathrm{~V}_{2} \mathrm{O}_{5}$ & & \\
\hline
\end{tabular}

Fonte: Zarzycki (1991)

\subsubsection{Os vidros sodo-cálcicos}

Os vidros sodo-cálcicos são talvez os menos custosos e os mais amplamente usados de todos os vidros comerciais. Mais de $90 \%$ da produção mundial de vidro compreende este tipo de vidro (SCHAEFFER, 1998). Os vidros sodo-cálcicos apresentam boa resistência química, alta resistividade elétrica e boa transmissão na região do visível (VARSHNEYA, 1993).

A maior parte dos produtos de vidro como os vidros de embalagem, vidros planos e vidros automotivos são fabricados a partir de vidros sodo-cálcicos. Estes produtos são fabricados por meio de processos contínuos de fusão, utilizando matérias-primas industriais, tais como areia, barrilha, calcário, compostos de alumina, caco de vidro e outros componentes. A mistura das matérias-primas é normalmente fundida entre 1300 e $1600{ }^{\circ} \mathrm{C}$ dependendo da taxa de produção, composição e qualidade requerida do vidro (BEST, 1994). As composições químicas típicas dos vidros sodo-cálcicos comerciais são apresentadas na Tabela 2.4 . 
Tabela 2.4 - Composições químicas dos vidros sodo-cálcicos comerciais.

\begin{tabular}{cccc}
\hline Óxidos & \multicolumn{3}{c}{ Porcentagem em massa (\%) } \\
& $\begin{array}{c}\text { Vidro de } \\
\text { janela }\end{array}$ & $\begin{array}{c}\text { Vidro de } \\
\text { embalagem }\end{array}$ & $\begin{array}{c}\text { Vidro de } \\
\text { lâmpada }\end{array}$ \\
\hline $\mathrm{SiO}_{2}$ & 73 & 74 & 72 \\
$\mathrm{Na}_{2} \mathrm{O}$ & 14 & 13 & 16 \\
$\mathrm{~K}_{2} \mathrm{O}$ & & 0,3 & 1 \\
$\mathrm{MgO}$ & 4 & 0,2 & 4 \\
$\mathrm{CaO}$ & 9 & 11 & 3 \\
$\mathrm{Al}_{2} \mathrm{O}_{3}$ & 0,1 & 1,5 & 2 \\
$\mathrm{Fe}_{2} \mathrm{O}_{3}$ & 0,1 & 0,04 & \\
$\mathrm{SO}_{2}$ & \multicolumn{4}{c}{0,2} \\
\hline
\end{tabular}

Fonte: Shelby (2005)

\subsubsection{Vidro de embalagem}

As embalagens de vidro são amplamente utilizadas para conter bebidas, produtos alimentícios, medicamentos, perfumes, cosméticos e outros artigos. Por ordem de consumo, a maior utilização é a do setor de bebidas, principalmente cervejas, seguida pela indústria de alimentos e logo após, produtos não alimentícios, sobretudo farmacêuticos e cosmétiCos (ABIVIDRO, 2009). A maior parte dos vidros para embalagens comerciais é fabricada a partir de vidros sodo-cálcicos. Estes vidros podem conter também pequenas quantidades de $\mathrm{MgO}, \mathrm{K}_{2} \mathrm{O}$ e $\mathrm{SO}_{3}$, o qual é utilizado durante na fabricação do vidro como afinante ${ }^{1}$. Outras embalagens utilizadas na indústria química e farmacêutica podem ser feitas de vidros borossilicatos, os quais possuem maior durabilidade e maior resistência ao ataque químico (SHELBY, 2005).

Os recipientes de vidro possuem uma série de vantagens indiscutíveis em relação a outras formas de embalagem: transparência, inércia química, proteção mecânica e a possibilidade de reciclagem. As embalagens de vidro podem ser retornáveis, reutilizáveis e totalmente recicláveis, sem perda de volume e das suas propriedades químico-físicas. Estima-se que a utilização de $10 \%$ de caco de vidro no processo de fabricação de vidro reduz em torno de $5 \%$ as emissões de $\mathrm{CO}_{2}$ e produz um de ganho energético de aproximadamente $4 \%$ no processo de fusão das matérias-primas (ABIVIDRO, 2009).

\footnotetext{
${ }^{1}$ Afinante é o termo utilizado para designar determinados compostos utilizados na fabricação de vidros, os quais a altas temperaturas liberam grandes quantidades de gases e formam grandes bolhas que sobem rapidamente para superfície do material fundido e arrastam com elas pequenas bolhas contidas na massa do vidro provocadas pela reação das outras matérias-primas (SHELBY, 2005).
} 
Outra característica muito importante da utilização do vidro como material de embalagem está associada à propriedade de proteção contra a radiação ultravioleta e luz visível de onda curta, ambas prejudiciais para a conservação de alimentos, bebidas e medicamentos. Embalagens de vidro podem absorver seletivamente determinados tipos de comprimentos de onda dependendo do tipo de corante introduzido na composição do vidro. Os vidros de embalagem com propriedades de proteção contra a radiação ultravioleta mais amplamente utilizados no mercado são os vidros de cor ver e marrom/âmbar.

Nos últimos anos, o segmento de embalagens na indústria de vidro tem deixado de ser somente um insumo e tem passado a assumir uma posição estratégica no setor vidreiro. Segundo dados da Associação Técnica Brasileira das Indústrias Automáticas de Vidro (ABIVIDRO) a participação do segmento de embalagens corresponde aproximadamente a terceira parte $(34,9 \%)$ do total de vendas/produção brasileira de vidros (Figura 2.2).

Figura 2.2 - Produção de vidro no Brasil.

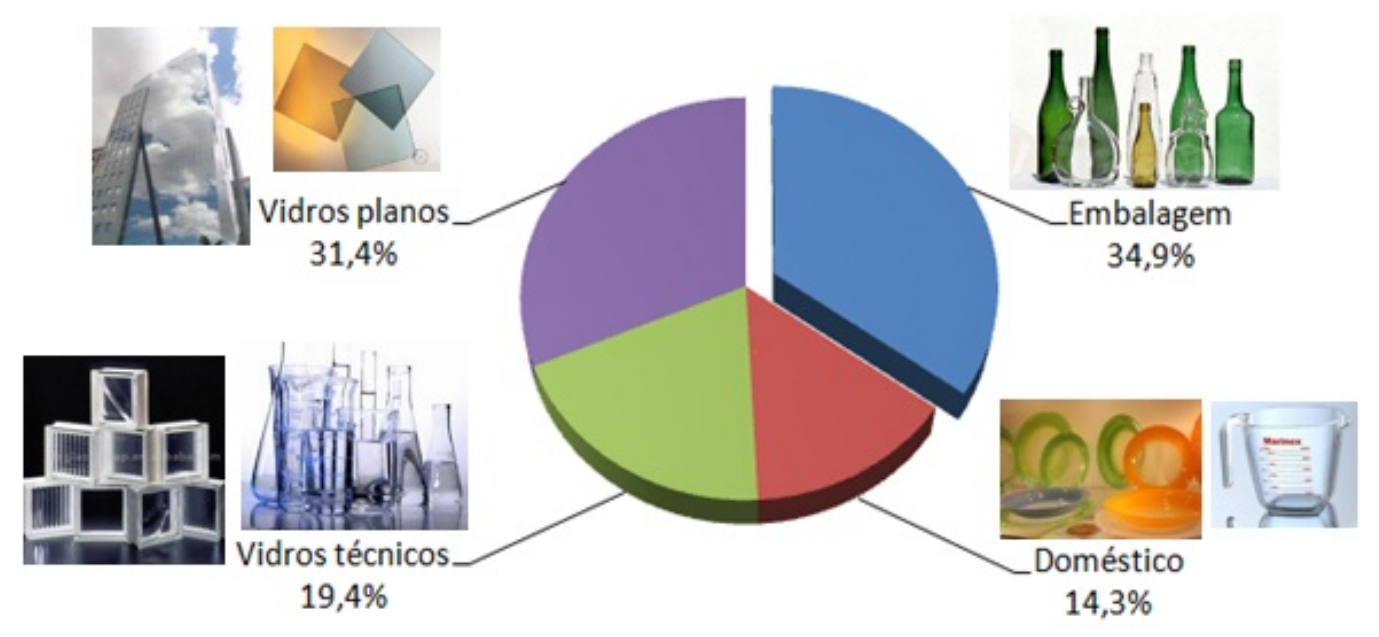

Fonte: ABIVIDRO (2009)

\subsection{A cor}

A percepção da cor não pode ser descrita como um fenômeno físico absoluto e sim como uma experiência subjetiva, em que os fatores fisiológicos e psicológicos também têm um papel importante (NASSAU, 1997). Percebemos cor devido à ação de um feixe de luz que estimula de forma seletiva vários tipos de fotorreceptores, que transformam o estimulo físico em respostas fisiológicas neurais. A cor é uma experiência humana resultante de estímulos externos e eventos neurais subsequentes na retina e no cérebro (SHEVELL, 2003). 
A luz visível no sentido mais estrito é aquela parte do espectro eletromagnético que é percebido pelo olho humano. A luz visível se encontra dentro de uma região muito estreita do espectro, com comprimentos de onda que variam aproximadamente entre $0,4 \mu \mathrm{m}$ e $0,7 \mu \mathrm{m}$, como é mostrado na Figura 2.3 (CALLISTER, 2001). O espectro eletromagnético pode ser descrito usando diversas unidades de medidas, em função do seus comprimentos de ondas (usualmente expressos em nanômetros, nm), frequência (medida em ciclos/segundo ou Hertz) ou em unidades de energia, tais como elétron volts (NASSAU, 1998). As faixas espectrais para as várias cores, assim como seus valores em Hertz e elétrons volts, são apresentadas na Figura 2.4.

Figura 2.3 - Espectro electromagnético e região do espectro visível.

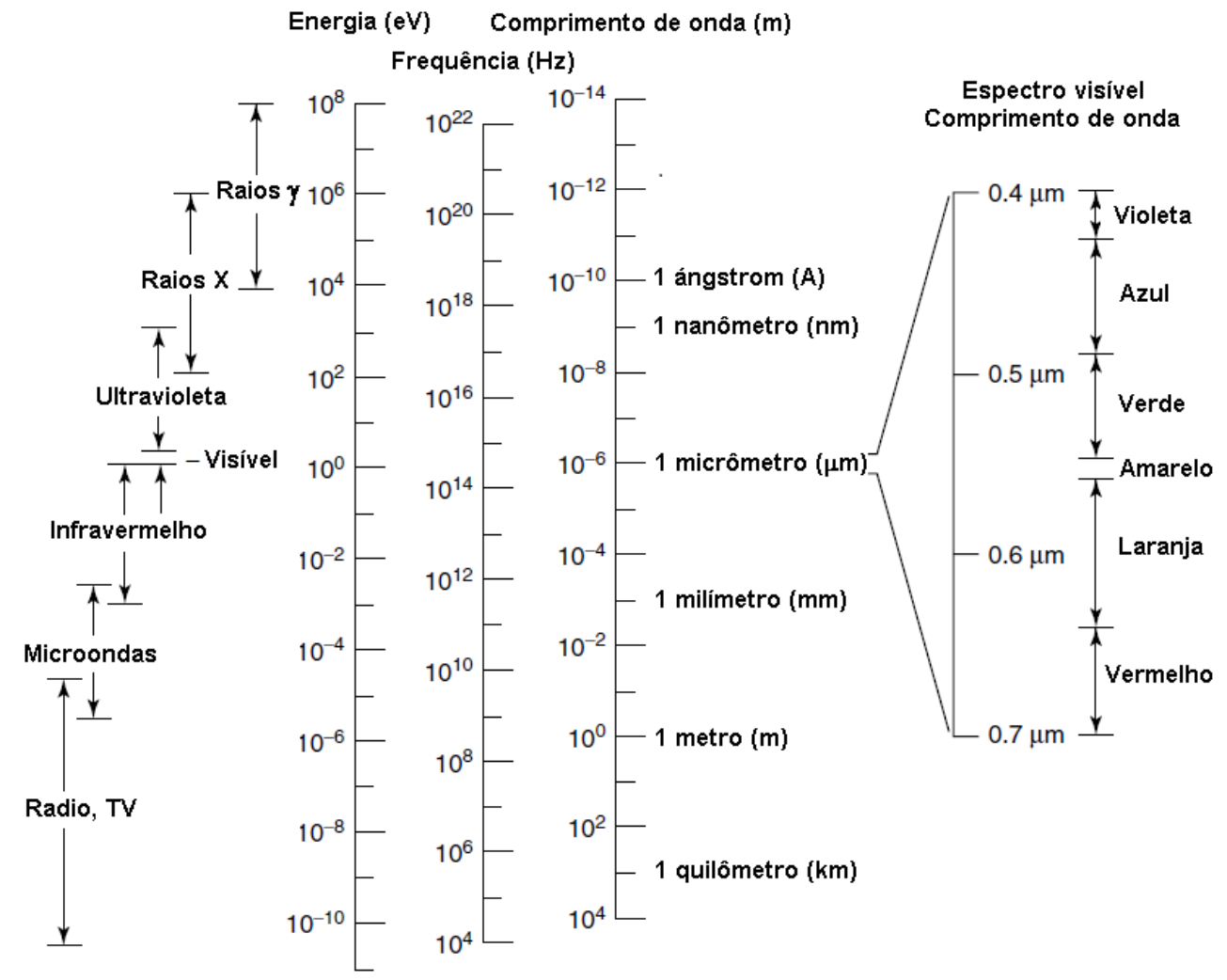

Fonte: Callister (2001)

A cor percebida é determinada pelo comprimento de onda. Por exemplo, a radiação com um comprimento de onda de aproximadamente $0,4 \mu \mathrm{m}$ aparece como violeta, enquanto que o verde e vermelho ocorrem ao redor de 0,5 e $0,65 \mu \mathrm{m}$, respectivamente. A luz branca é simplesmente uma mistura de todas as cores (CALLISTER, 2001). Deste modo, percebemos a ampla variedade de cores quando os diferentes comprimentos de onda que compõem a luz branca são seletivamente interferidos pela matéria (absorvidos, refletidos, refratados, dispersos, ou difratados) durante seu caminho para os nossos olhos, ou quando uma distribuição não-branca de luz é emitida por algum sistema (NASSAU, 1987). 
Figura 2.4 - Comprimentos de onda para as faixas espectrais das cores e seus valores correspondentes em Hertz e electrons volts.

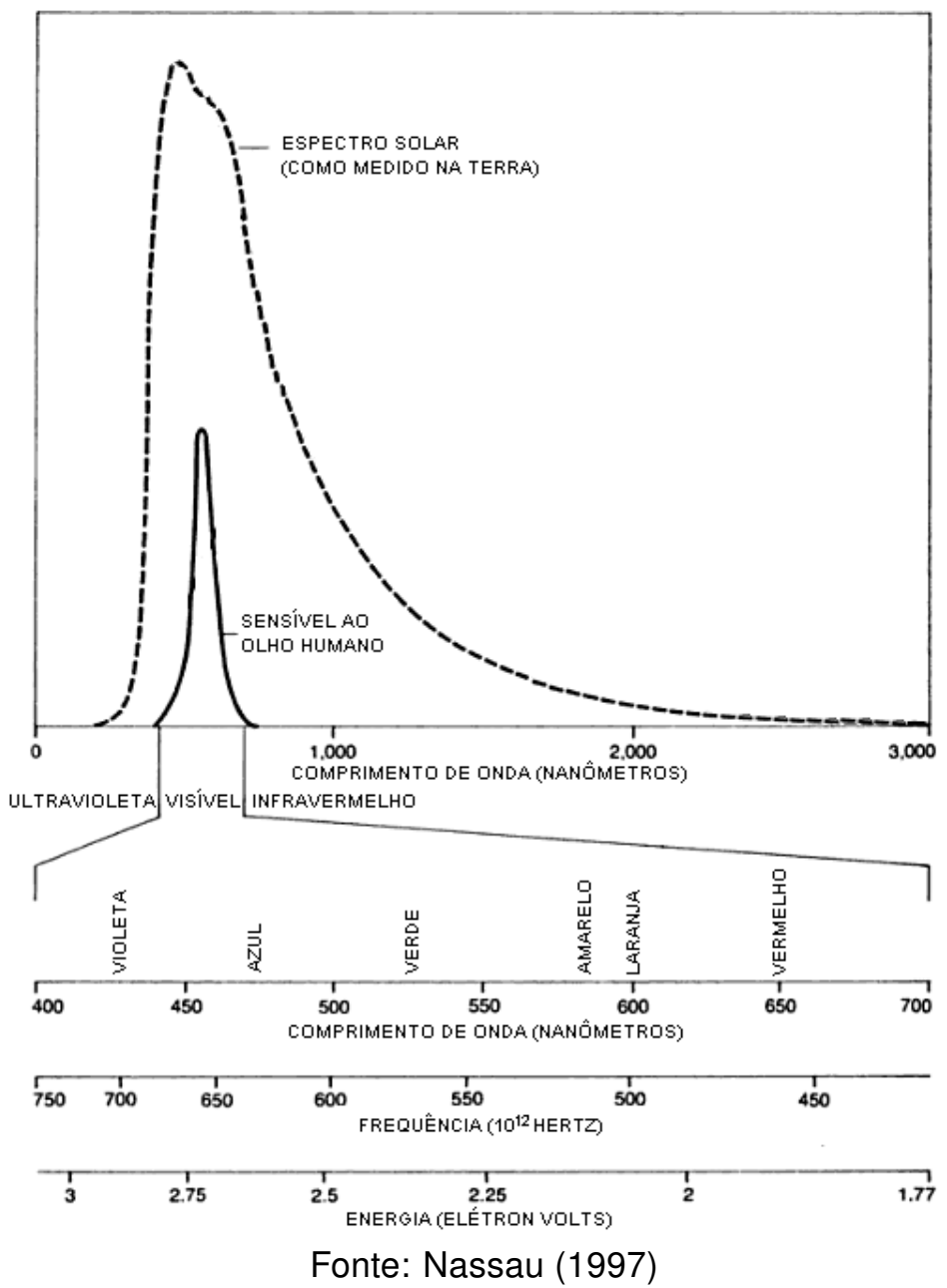

\subsubsection{Medição da cor}

A medição da cor é de grande importância em muitas aplicações comerciais, principalmente nas indústrias têxtil, de tintas e de produtos alimentícios, desempenhando também um papel importante nas indústrias de iluminação, impressão, papel, cosméticos, plásticos, vidro, química, televisão, fotográfica, transporte e comunicação (HUNT; POINTER, 2011).

Ao longo dos anos, uma ampla variedade de sistemas de medição de cor tem sido desenvolvidas com o propósito de tentar simular matematicamente a percepção da cor e fornecer um procedimento padronizado para medir e quantificar essa percepção (MARCUS, 1998). Atualmente, o mais comum é o sistema de coordenadas de cor CIE $\mathrm{L}^{*} \mathrm{a}^{*} \mathrm{~b}^{*}$, também conhecido como sistema CIELAB, o qual foi desenvolvido em 1976 pela Comissão Internacional de Iluminação, conhecida internacionalmente como CIE (Commission International de l'Eclairage). 
A CIE é a organização mundial, independente e sem fins lucrativos, encarregada de todos os aspectos relacionados com a ciência e a arte da luz, cor e visão, assim como também da fotobiologia e tecnologia de imagem (CIE, 2013). Desde sua criação em 1913, a CIE tornou-se uma organização profissional, com fortes fundamentos técnicos, científicos e culturais, e tem sido aceita como a autoridade máxima no assunto e, como tal, é reconhecida pela Organização Internacional de Normalização (ISO) como um organismo de normalização internacional (CIE, 2013).

O modelo de cor CIE esta baseado na percepção das cores pelo sistema visual humano e se diferença dos outros modelos pela padronização das fontes de luz (iluminantes) e da sensibilidade do olho humano aos vários comprimentos de onda (observador). Os iluminantes padrões mais usados são o D50 e D65 e os observadores padrões podem ser de $2^{\circ}$ (dois graus) e $10^{\circ}$ (dez graus).

O sistema CIELAB permite a especificação de percepções de cores num espaço tridimensional (Figura 2.5). A localização de qualquer cor neste espaço pode ser determinada por suas coordenadas de cor: $L^{*}, a^{*}, e b^{*}$. $O$ valor $L^{*}$ representa a luminância (luminosidade) e pode variar de 0 a 100, um branco perfeito teria um $L^{*}$ igual a 100 , e um negro perfeito teria um $L^{*}$ igual a 0 (MARCUS, 1998). A coordenada $a^{*}$ representa a diferença entre verde $\left(-a^{*}\right)$ e vermelho $\left(+a^{*}\right)$ enquanto a coordenada $b^{*}$ correlaciona a diferença entre azul $\left(-b^{\star}\right)$ e amarelo $\left(+b^{\star}\right)$ (SAHIN; SUMNU, 2006).

Figura 2.5 - Sistema de coordenadas CIELAB.

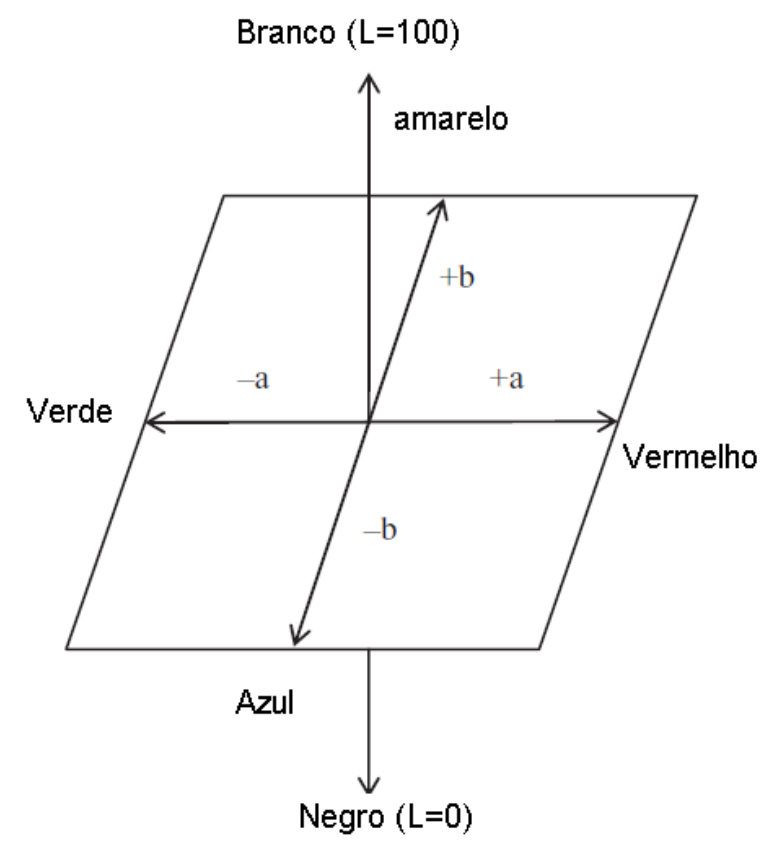

Fonte: Sahin e Sumnu (2006) 


\subsubsection{As causas da cor}

Embora a forma mais comum de interação entre a luz e a matéria para gerar cor envolva luz e elétrons, tais interações são bastante diversificadas e outros mecanismos, tais como a dispersão e a interferência também devem ser considerados. Segundo Nassau (1983) existem quinze mecanismos físicos e químicos específicos pelos quais pode ser descrito o fenômeno da cor, os quais por sua vez, podem ser agrupados em cinco grandes grupos com base nos mecanismos fundamentais envolvidos. Na Tabela 2.5 são apresentadas de forma resumida as quinze causas de cor descritas por Nassau (1983).

Tabela 2.5 - As quinze causas da cor e alguns exemplos.

\begin{tabular}{|c|c|}
\hline \multicolumn{2}{|r|}{ Causas da cor } \\
\hline \multicolumn{2}{|r|}{ Vibração e excitação simples } \\
\hline 1. & Incandescência: lâmpadas de filamento, pirotécnicos \\
\hline 2. & Excitação de gases: lâmpadas de vapor, raios, alguns lasers \\
\hline 3. & Vibração e rotação: cor azul do água e gelo, iodo \\
\hline \multicolumn{2}{|r|}{ Transições envolvendo efeitos de campo ligante } \\
\hline 4. & $\begin{array}{l}\text { Compostos de metais de transição: turquesa, vários pigmentos, } \\
\text { verde cromo, alguns materiais fluorescentes, fosforescentes e lasers }\end{array}$ \\
\hline 5. & $\begin{array}{l}\text { Impurezas de metais de transição: rubi, esmeralda, cor vermelho } \\
\text { do minério de ferro, alguns materiais fluorescentes e lasers }\end{array}$ \\
\hline \multicolumn{2}{|r|}{ Transições entre orbitais moleculares } \\
\hline 6. & $\begin{array}{l}\text { Compostos orgânicos: a maioria de tintas, a maioria de cores biológicas, } \\
\text { alguns materiais fluorescentes e lasers }\end{array}$ \\
\hline 7. & Transferência de carga: azul safira, magnetita, muitos pigmentos \\
\hline \multicolumn{2}{|r|}{ Transições envolvendo bandas de energia } \\
\hline 8. & Metais: cobre, prata, ouro, ferro, latão, vidro rubi \\
\hline 9. & Semicondutores puros: silício, galena, cinábrio, diamante \\
\hline 10. & $\begin{array}{l}\text { Semicondutor dopado: diamante azul e amarelo, diodos emissores de luz, } \\
\text { alguns materiais fosforescentes e lasers }\end{array}$ \\
\hline & $\begin{array}{l}\text { Centros de color: ametista, quartzo enfumaçado, alguns materiais } \\
\text { fluorescentes e lasers }\end{array}$ \\
\hline
\end{tabular}

\section{Ótica geométrica e física}

12. Refração dispersiva: arco-íris, brilho verde do sol, pedras preciosas

13. Espalhamento: cor azul do céu, por do sol vermelho, penas de aves, olhos azuis, borboletas e algumas outras cores biológicas

14. Interferência: manchas de óleo na água, revestimento de lentes de câmera, bolhas de sabão, algumas cores biológicas

15. Difração: CD-rom, algumas cores biológicas, a maioria de cristais líquidos

Fonte: Nassau (1983) 


\subsubsection{A cor nos vidros}

A ampla gama de cores observadas nos vidros, assim como nos vidrados e esmaltes, pode ser produzida por uma grande variedade de procedimentos diferentes. Estes incluem a adição de íons de metais de transição, íons de terras raras, sulfatos, fosfatos, compostos de cadmio, precipitação de partículas metálicas coloidais (ouro, cobre e prata) entre outros. Os diferentes compostos utilizados para produzir cor nos vidros, assim como os mecanismos físicos e químicos envolvidos, são apresentados de maneira resumida na Tabela 2.6.

Tabela 2.6 - Compostos utilizados para produzir cor em vidros, vidrados e esmaltes.

\begin{tabular}{|c|c|c|}
\hline Aditivo ou tratamento & Cor & Mecanismo \\
\hline $\begin{array}{l}\text { Metais de transição com } \\
\text { elétrons não emparelhados }\end{array}$ & ampla variedade & campo ligante \\
\hline Sulfuretos de Ferro, $\mathrm{V}^{5+}, \mathrm{Cr}^{6+}$ & amarelo, marrom, preto & transferência de carga \\
\hline Ouro, cobre, prata & amarelo, vermelho, roxo & espalhamento metálico \\
\hline Compostos de Cadmio-selênio & $\begin{array}{l}\text { amarelo, laranja, } \\
\text { vermelho, preto }\end{array}$ & semicondutores \\
\hline Irradiação & roxo & centro de cor \\
\hline Fluoretos, etc & (translúcido a opaco) & espalhamento \\
\hline
\end{tabular}

Fonte: Nassau (1983)

Os vidros comerciais mais importantes são principalmente coloridos pela adição de íons de metais de transição 3d ou terras raras $4 f$ (lantanídeos) (SHELBY, 2005). A coloração destes vidros é causada por transições eletrônicas internas, que envolvem energias menores, entre os níveis de energia do seu orbital incompleto em elétrons, transições $d$ - $d$ no caso dos metais de transição e transições f-f no caso das terras raras (TILLEY, 2008).

Íons de metais de transição com orbitais $3 d$ incompletos, quando isolados, possuem níveis de energia idênticos. No entanto, quando um íon de metal de transição está rodeado por outros ânions (denominados ligantes) tal como ocorre num cristal ou num vidro, a presença do vizinho ligante provoca a separação dos níveis de energia em novos níveis (SHELBY, 2005). As diferenças de energia entre estes novos níveis são relativamente pequenas e comumente se encontram no intervalo de 1 a $3 \mathrm{eV}$, que corresponde à faixa de energia do espectro visível. Deste modo, a absorção de fótons por transições eletrônicas entre os novos níveis $3 d$, pode ocorrer na região visível do espectro produzindo a cor (SHELBY, 2005). 
As cores produzidas pela adição de metais de transição nos vidros podem variar consideravelmente dependendo da sua configuração eletrônica, bem como da composição química e estrutura do vidro base. Por exemplo, o número de coordenação dos cátions em vidros silicatos é predominantemente tetraédrico. Nesta situação a adição de cobalto produzirá a bem conhecida cor "azul cobalto", uma intensa coloração azul violeta, detectável mesmo em concentrações de umas poucas partes por milhão. Por outro lado, o número de coordenação dos vidros fosfato é octaédrica e sob esta condição a adição de cobalto conferira uma suave coloração cor-de-rosa ao vidro (NASSAU, 1983).

Existe também um forte efeito da valência na cor. Por exemplo, a presença do $\mathrm{Fe}^{2+}$ confere ao vidro uma cor verde-azulada ao vidro, enquanto que a mesma quantidade de $\mathrm{Fe}^{3+}$ produz um vidro quase incolor (NASSAU, 1983). As cores geradas pela presença de íons de metais de transição em vidros sodo-cálcicos e outros vidros são apresentadas na Tabela 2.7. A coloração no vidro pode ser influenciada também pela posição que os metais de transição ocupam na estrutura do vidro, podendo atuar como formadores ou como modificadores da rede. Na Tabela 2.8 pode-se observar as variações de cor segundo a posição dos íons colorantes na estrutura do vidro.

Tabela 2.7 - Cores em vidros sodo-cálcicos e outros vidros.

\begin{tabular}{lll}
\hline Ion & Cor em vidros sodo-cálcicos & Cores em outros vidros \\
\hline $\mathrm{Ti}^{3+}$ & violeta-roxo & - \\
$\mathrm{V}^{4+}$ & - & azul \\
$\mathrm{V}^{3+}$ & amarelo-verde & - \\
$\mathrm{Cr}^{3+}$ & verde & amarelo-laranja \\
$\mathrm{Cr}^{2+}$ & - & azul \\
$\mathrm{Mn}^{3+}$ & roxo & - \\
$\mathrm{Mn}^{2+}$ & incolor & amarelo, marrom \\
$\mathrm{Fe}^{3+}$ & amarelo claro-verde & incolor \\
$\mathrm{Fe}^{2+}$ & verde azul & amarelo, cor-de-rosa \\
$\mathrm{Co}^{3+}$ & - & amarelo \\
$\mathrm{Co}^{2+}$ & violeta escuro-azul & cor-de-rosa, vermelho \\
$\mathrm{Ni}^{2+}$ & amarelo, marrom & roxo \\
$\mathrm{Cu}^{2+}$ & azul, verde & - \\
\hline
\end{tabular}

Fonte: Nassau (1983)

Alem de conferir cor, metais de transição também podem ser usados para conferir outras propriedades especiais aos vidros. Por exemplo, a adição de níquel mais cobalto produz negro, conferindo ao vidro total absorção no visível, mas permitindo a transmissão do ultravioleta. Titânio, cério ou ferro bivalente podem ser utilizados para fornecer ao vidro a propriedade de absorver parte da energia térmica incidente. Estes vidros são utilizados 
em projetores de diapositivos e outros equipamentos similares para remover grandes quantidades de radiação infravermelha produzida pelas lâmpadas incandescentes, mas permitindo a passagem de luz visível (NASSAU, 1983).

Tabela 2.8 - Cores correspondentes à posição do íon colorante na rede do vidro.

\begin{tabular}{lll}
\hline Ion & Formador de rede & Modificador de rede \\
\hline $\mathrm{Cr}^{3+}$ & - & verde \\
$\mathrm{Cr}^{6+}$ & amarelo & - \\
$\mathrm{Cu}^{2+}$ & marrom-amarelo & azul \\
$\mathrm{Cu}^{1+}$ & - & incoloro, pardo fluorescente \\
$\mathrm{Co}^{2+}$ & azul & rosa \\
$\mathrm{Ni}^{2+}$ & púrpura & amarelo \\
$\mathrm{Mn}^{2+}$ & incolor, verde fluorescente & laranja suave, vermelho fluorescente \\
$\mathrm{Mn}^{3+}$ & púrpura & - \\
$\mathrm{Fe}^{2+}$ & - & verde escuro \\
$\mathrm{Fe}^{3+}$ & pardo escuro & amarelo pálido \\
$\mathrm{V}^{3+}$ & - & verde \\
$\mathrm{V}^{4+}$ & - & azul \\
$\mathrm{V}^{5+}$ & incolor a amarelo & - \\
\hline
\end{tabular}

Fonte: Salmang (1962)

\subsubsection{Vidros verdes de embalagem}

Os vidros de embalagem de coloração verde são outro exemplo importante de vidros com propriedades especiais conferidas pela adição de metais de transição. A maioria deles é fabricado adicionando quantidades variáveis de $\mathrm{Cr}_{2} \mathrm{O}_{3}$ e $\mathrm{Fe}_{2} \mathrm{O}_{3}$. No entanto, alguns outros tipos de vidros verdes também podem incluir óxido de cobalto na sua composição (VOLF, 1984; SKOUROUMOUNIS et al., 2003).

Vidros de coloração verde são amplamente utilizados como recipientes na indústria de alimentos (principalmente em bebidas como cerveja, vinhos e refrigerantes) devido à sua propriedade de absorção de radiação UV. Como é sabido, quando expostas à radiação UV muitas bebidas sofrem alterações no seu aroma, sabor e características benéficas para a saúde pelas quais são valorizadas (ZHERNOVAYA; ONISHCHUK; DAVYDOGLU, 2007). Os vidros de coloração verde têm a capacidade de proteger o seu conteúdo, pois absorvem a radiação UV. É importante mencionar também que esta característica não se deve exclusivamente à presença do $\mathrm{Cr}_{2} \mathrm{O}_{3}$ no vidro e sim de modo majoritário pela ação de $\mathrm{Fe}_{2} \mathrm{O}_{3}$, o qual apresenta uma forte absorção na região do UV (VOLF, 1984). Isto pode ser observado mais claramente quando comparamos as curvas de absorção óptica dos vidros contendo cromo e ferro em diferentes estados de valência (Figura 2.6). 
Figura 2.6 - Espectros de absorção óptica de vidros silicatos coloridos com cromo (a) e ferro (b) em diferentes estados de valência.
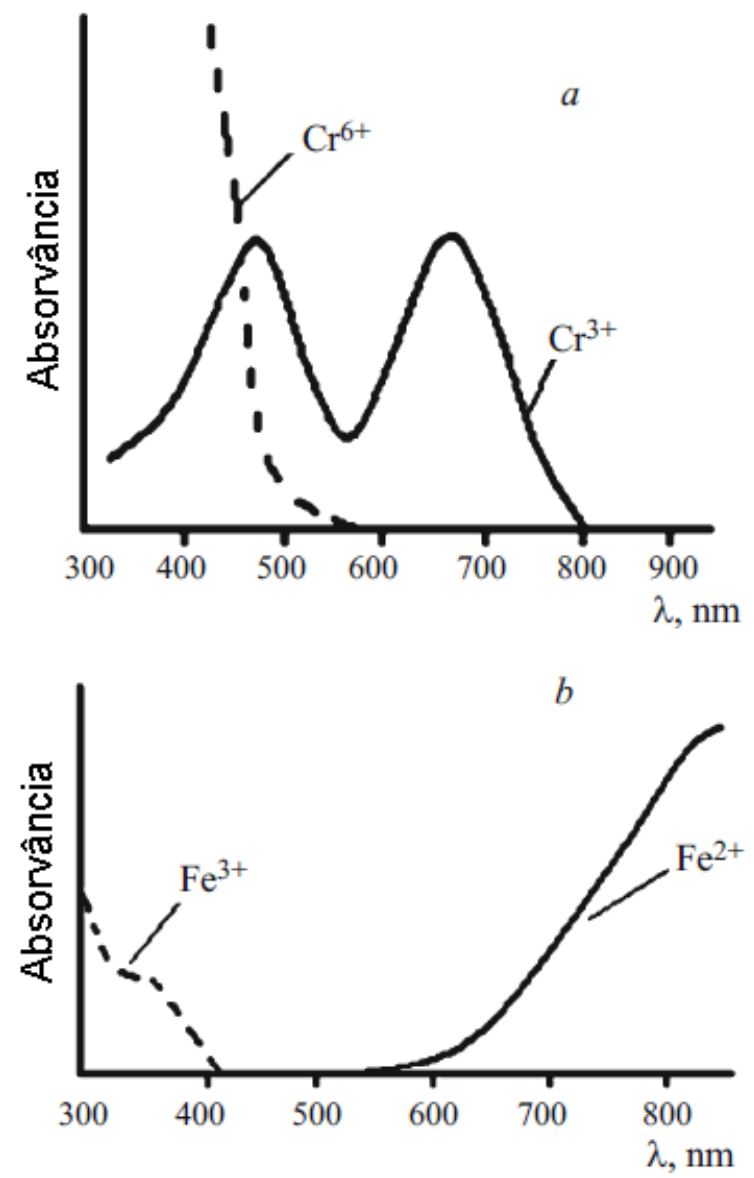

Fonte: Atkarskaya et al. (2011)

Existe uma ampla variedade de vidros verdes de embalagem produzidos no mundo, denominados comercialmente como "emerald green", "antique green", "french green", entre muitos outros. No Brasil o tipo de vidro verde de embalagem mais amplamente utilizado é o "olive green" ou verde oliva o qual apresenta na sua composição baixos teores de $\mathrm{Cr}_{2} \mathrm{O}_{3}\left(0,02-0,2 \%\right.$ massa), $\mathrm{Fe}_{2} \mathrm{O}_{3}$ (0,1-0,4 \% massa) e $\mathrm{S}^{-2}$ (0,01-0,04\% massa) (MILLS; JASINSKI, 1982). No Brasil as fontes de cromo e ferro utilizadas para a fabricação de vidros verdes são, respectivamente, a cromita e a hematita.

Outros tipos de vidros de embalagem que realizam a mesma função de proteção contra radiação ultravioleta são os vidros de coloração âmbar, que são comumente usados como recipientes de cervejas e produtos farmacêuticos devido a oferecerem uma proteção mais intensa da radiação ultravioleta, como pode ser observado nas curvas de transmissão óptica apresentadas na Figura 2.7. 
Figura 2.7 - Espectros de transmissão óptica dos vidros de embalagem verde (1) e âmbar (2).

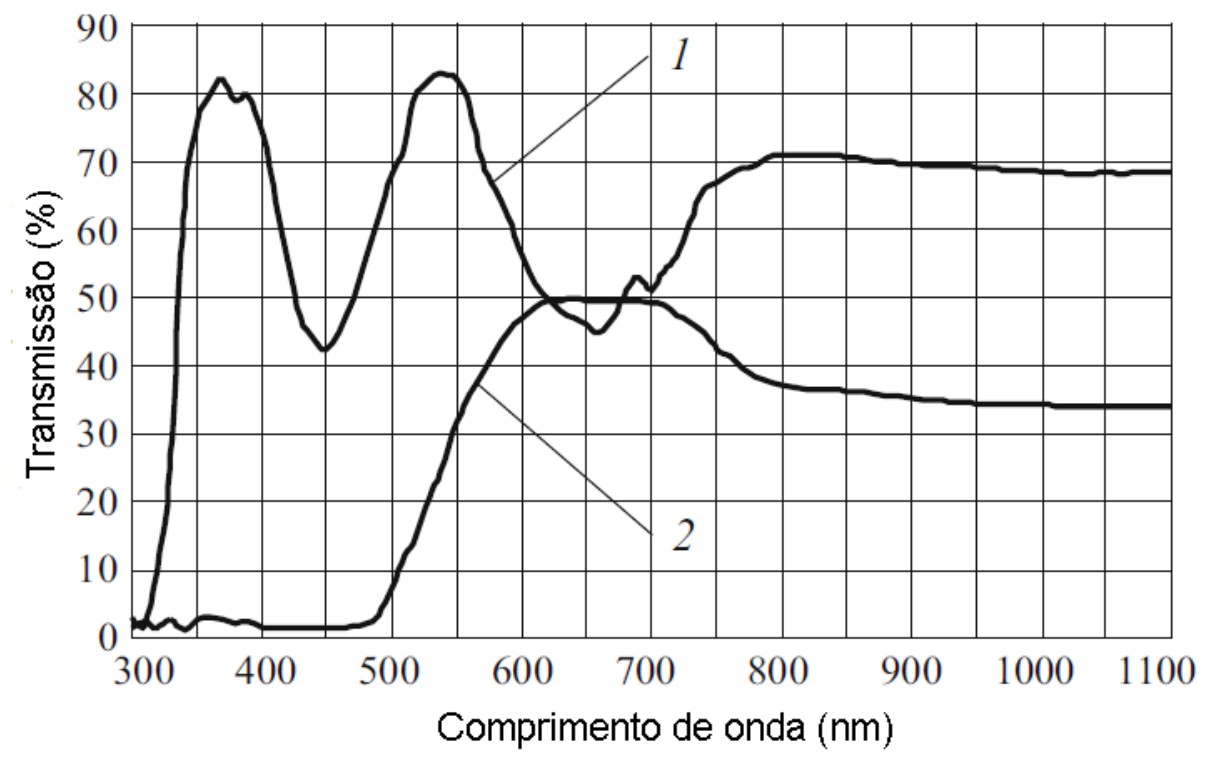

Fonte: Zhernovaya, Onishchuk e Davydoglu (2007)

\subsection{Reações de óxido-redução nos vidros}

Quando um metal de transição é introduzido numa massa de vidro fundido, este pode distribuir-se em diferentes estados de valência. Este fenômeno é causado pelas reações de oxidação e redução que ocorrem na massa fundida, as quais dependem fortemente da composição da massa fundida, do tempo e temperatura de fusão, e da atmosfera do forno (PAUL, 1985). A passagem dos íons polivalentes de um estado de valência a outro pode ser descrita segundo a reação abaixo, onde n é o numero de elétrons que são transferidos quando um íon polivalente passa de um estado de valência a outro.

$$
\mathrm{M}^{(x+n)+}+\mathrm{ne}^{-} \underset{\text { redução }}{\stackrel{\text { oxidação }}{\text { (n) }}} \mathrm{M}^{x+}
$$

As reações de óxido-redução desempenham um papel muito importante na fabricação de vidros comerciais, particularmente na obtenção de vidros homogêneos livres de bolhas e para conferir coloração adequada aos vidros mediante a adição de metais de transição (PAUL, 1990; ZHERNOVAYA; ONISHCHUK; DAVYDOGLU, 2007; MÜER-SIMON, 2004). Além de ter uma forte influencia nas características finais do vidro, as reações de óxido-redução afetam também muitos parâmetros do processo de produção do vidro, tais como a condução de calor da massa fundida (tanto no tanque de fusão assim como no molde), o fluxo do vidro no interior do tanque, a viscosidade, o comportamento visco-elástico e a tensão superficial (MÜER-SIMON, 2004). 


\subsubsection{Influência da pressão parcial de oxigênio}

Sob condições de equilíbrio, existe uma proporção direita entre a relação das concentrações da forma oxidada e da forma reduzida, $\left[\mathrm{Me}^{(x+n)+}\right] /\left[\mathrm{Me}^{x+}\right]$, e a Pressão Parcial de Oxigênio $\left(\mathrm{pO}_{2}\right)$. A uma temperatura constante a quantidade de oxigênio dissolvido no vidro fundido aumenta linearmente com o $\log \mathrm{p}_{\mathrm{O}_{2}}$ (Figura 2.8). Os elementos que são oxidados ou reduzidos permanecem geralmente dissolvidos no vidro rodeando-se de oxigênios e formando poliedros com coordenação determinada. Em alguns casos, sob condições fortemente redutoras, podem chegar ao estado elementar, como a solubilidade dos metais nos vidros fundidos é muito pequena, esta redução pode ser observada como um precipitado no vidro final.

Figura 2.8 - Variação da relações da forma oxidada e forma reduzida de distintos íons em função do $\log p_{O_{2}}$.

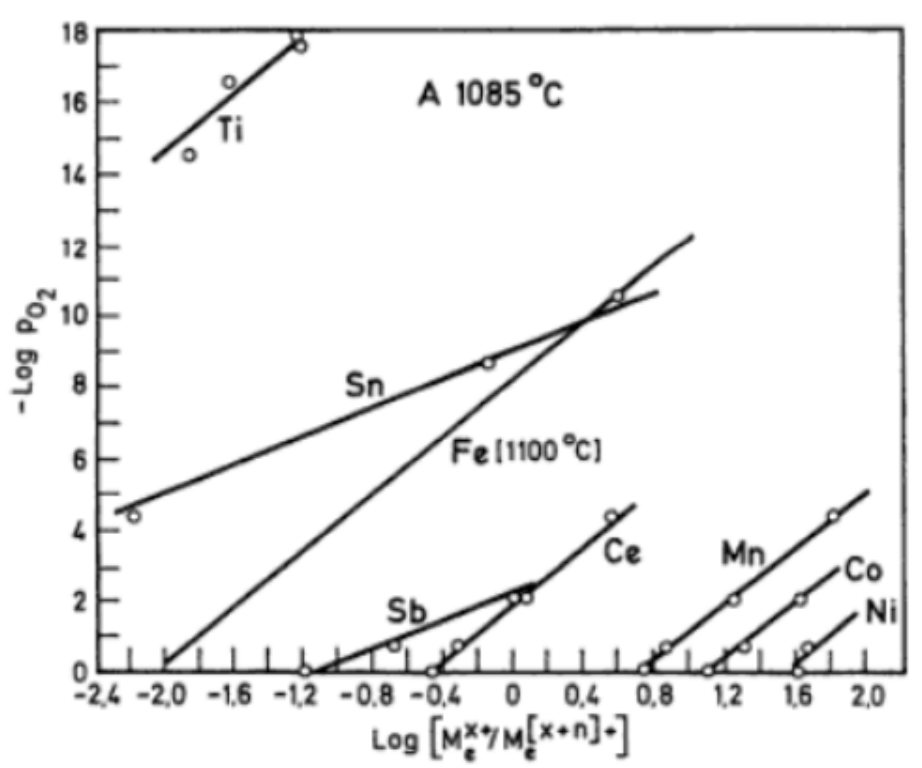

Fonte: Navarro (2003)

\subsubsection{Influência da composição do vidro}

Em quase todos os vidros relação $\left[\mathrm{Me}^{(x+n)+}\right] /\left[\mathrm{Me}^{x+}\right]$, ou concentração de oxigênio dissolvido, aumenta com o teor e tipo de álcalis presente no vidro. Para um vidro com o mesmo conteúdo em mols de álcalis, a alcalinidade varia em ordem crescente segundo a relação $\mathrm{Li}<\mathrm{Na}<\mathrm{K}$. Na Figura 2.9 pode se observar como a proporção de íons $\mathrm{Fe}^{3+}$ aumenta com a basicidade do vidro. O mesmo comportamento também tem sido observado experimentalmente para outros pares de íons metálicos, tais como o $\mathrm{Cr}^{3+}-\mathrm{Cr}^{6+}, \mathrm{Ce}^{3+}$. $\mathrm{Ce}^{4+}$ e $\mathrm{Mn}^{2+}-\mathrm{Mn}^{3+}$. 
Figura 2.9 - Variação da proporção de íons $\mathrm{Fe}^{3+}$ em vidros do sistema $\mathrm{R}_{2} \mathrm{O}-\mathrm{SiO}_{2}$ en função da porcentagem molar de alcalinos.

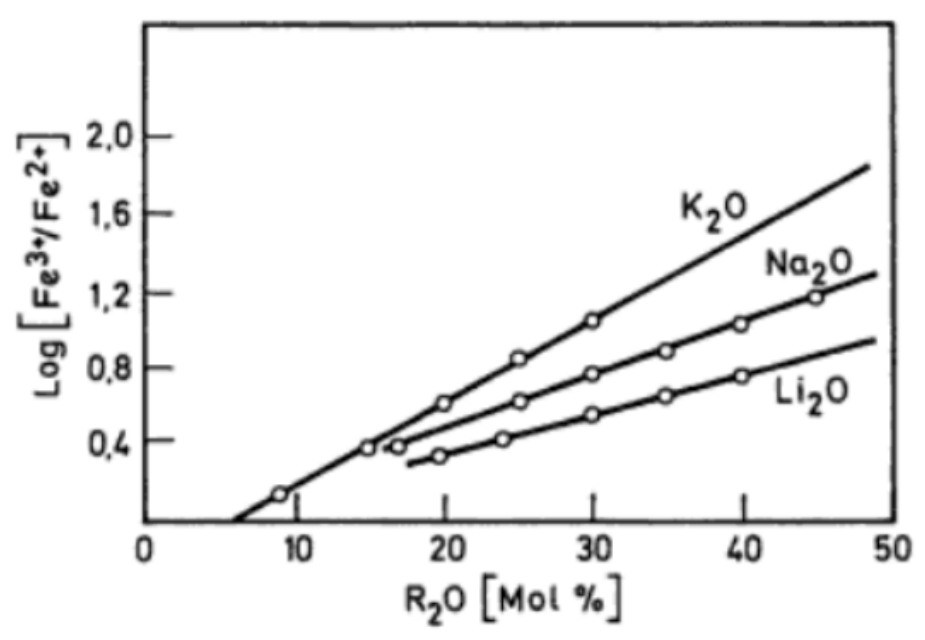

Fonte: Navarro (2003)

\subsubsection{Interação entre dois óxidos redox no vidro}

Íons polivalentes de diferentes elementos interagem quando presentes no mesmo vidro. Como resultados desta interação o estado de oxidação de cada elemento difere do estado de oxidação que teria sido alcançado para qualquer um deles, se estivesse presente sozinho no vidro (BAMFORD, 1978). Este fenômeno ocorre porque além do oxigênio, outros elementos polivalentes podem atuar como doadores ou receptores de elétrons na massa de vidro fundido.

Os primeiros estudos conduzidos para entender a natureza das interações entre determinados elementos foi realizada por Kuhl, Rudow e Weyl (1938) apud Bamford (1978). Baseados na analise dos espectros de absorção óptica de vidros do sistema sódio-cálciosílica, contendo várias combinações duplas de diferentes elementos, eles determinaram a sequencia de estabilidade dos estados de valência de vários íons multivalentes, os quais são apresentados na Tabela 2.9.

Tabela 2.9 - Serie de óxido-redução dos íons metálicos

\begin{tabular}{lc}
\hline Elemento & Íons multivalentes \\
\hline Cromo & $\mathrm{Cr}^{3+} / \mathrm{Cr}^{6+}$ \\
Manganês & $\mathrm{Mn}^{2+} / \mathrm{Mn}^{3+}$ \\
Cério & $\mathrm{Ce}^{3+} / \mathrm{Ce}^{4+}$ \\
Arsênico & $\mathrm{As}^{3+} / \mathrm{As}^{5+}$ \\
Antimônio & $\mathrm{Sb}^{3+} / \mathrm{Sb}^{5+}$ \\
Ferro & $\mathrm{Fe}^{2+} / \mathrm{Fe}^{3+}$ \\
\hline Fonte: Bamford (1978)
\end{tabular}


De acordo com a sequência estabelecida por Kuhl, Rudow e Weyl (1938), o equilíbrio iônico de qualquer elemento da série será deslocado na direção da forma com maior valência (forma mais oxidada) por qualquer elemento listado acima dele, e direcionado para a forma com menor valência por qualquer elemento listado abaixo dele.

Mais recentemente, Paul (1990) propôs a utilização do diagrama de Ellingham² ${ }^{2}$ como um método para determinar o comportamento de óxido-redução dos íons polivalentes no vidro. Na Figura 2.10 é apresentado o diagrama de Ellingham para alguns óxidos de interesse para a tecnologia do vidro. Nesta figura pode-se observar que os óxidos mais facilmente redutíveis se encontram na parte superior do diagrama, os óxidos de metal de transição encontram-se reunidos no meio, e os formadores de vidro convencional (muito mais estáveis), tais como $\mathrm{SiO}_{2}, \mathrm{~B}_{2} \mathrm{O}_{3}$ encontram-se na parte inferior do diagrama. Esta distribuição explica a razão pela qual, na formação do vidro contendo óxido de ferro, o $\mathrm{Fe}^{3+}$ pode ser reduzido a $\mathrm{Fe}^{2+}$ antes que ocorra a redução do $\mathrm{SiO}_{2}$ (PAUL, 1990).

Figura 2.10 - Diagrama de Ellingham para alguns óxidos de interesse para a tecnologia de vidros.

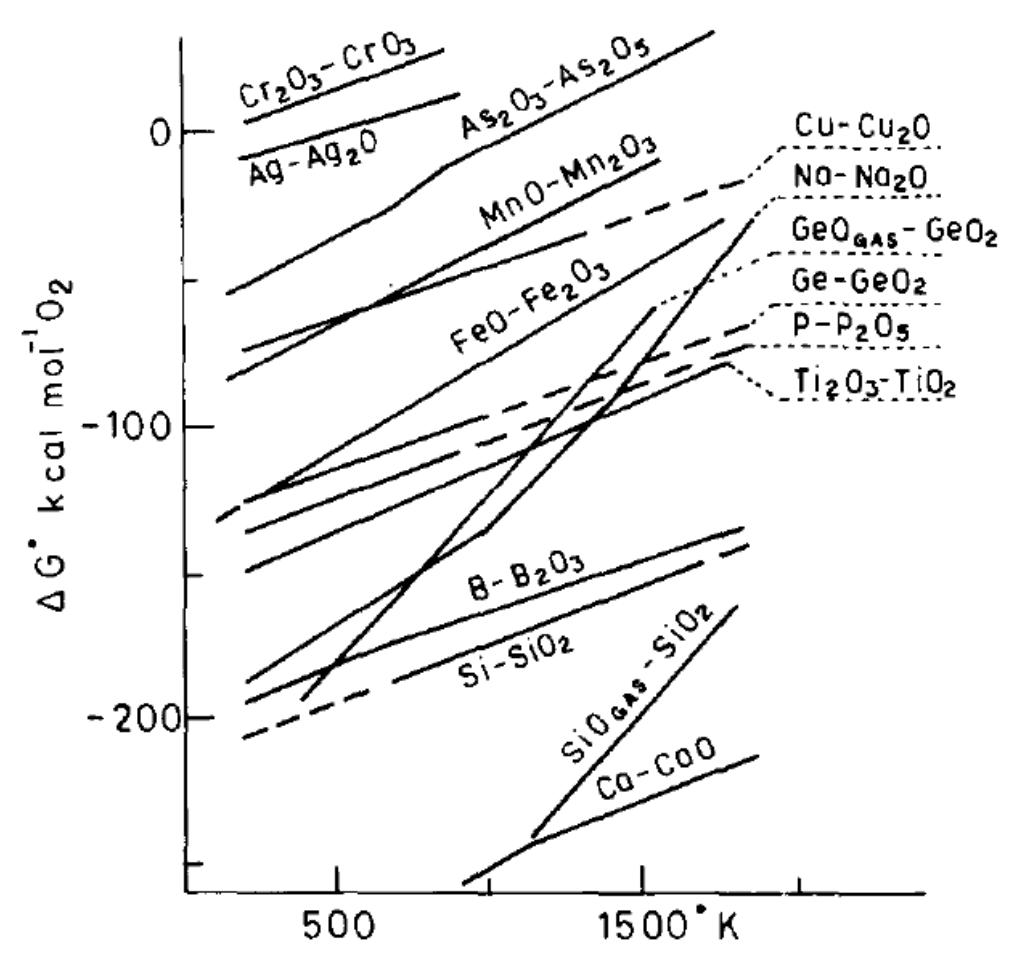

Fonte: Paul (1990)

\footnotetext{
${ }^{2}$ Os diagramas de Elligham são representações gráficas, determinadas experimentalmente, que relacionam a energia livre de Gibbs e a temperatura de uma grande variedade de compostos. Foram introduzidos por H. J. T. Ellingham, em 1944, para estudo de processos metalúrgicos envolvendo óxidos e sulfetos (SIMONI; CHAGAS, 2007).
} 
Embora o diagrama de Ellingham forneça informação importante sobre a interação dos íons polivalentes, ele é valido somente para óxidos puros. Óxidos de metais de transição não se misturam idealmente com o vidro, consequentemente são necessárias algumas correções nos dados da Figura 2.10 antes que possa ser utilizada adequadamente na fusão de vidros. Na Figura 2.11 são mostradas as correções para o $\mathrm{FeO}$ e $\mathrm{Na}_{2} \mathrm{O}$ em uma massa fundida de um vidro silicato. É importante mencionar que apesar da ter sido demonstrada a utilização do diagrama de Ellingham para determinar o comportamento de óxido-redução dos íons polivalentes no vidro, existe pouca literatura disponível relacionada ao desenvolvimento de diagramas de Ellingham para vidros.

Figura 2.11 - Diagrama de Ellingham do $\mathrm{FeO}$ e $\mathrm{Na}_{2} \mathrm{O}$ num vidro silicato.

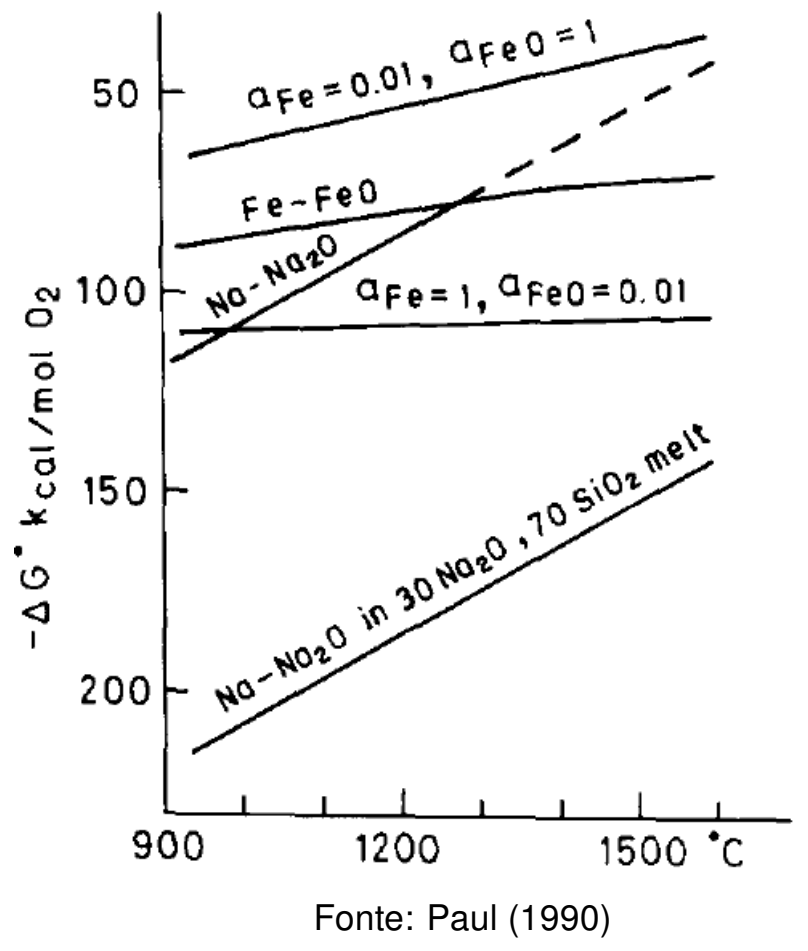

\subsubsection{Ajuste e controle do estado redox}

O estado de óxido-redução dos vidros comerciais é geralmente controlado pela adição de agentes de redução ou de oxidação na mistura vitrificável do vidro e não pela alteração da atmosfera do forno ou da temperatura da fusão (PAUL, 1990). Os agentes redutores mais utilizados na fabricação de vidro incluem o carbono, antracito, piritas de ferro e escórias. Os agentes oxidantes incluem o sulfato de sódio, óxido de cério e nitratos de sódio e de potássio (ZHERNOVAYA; ONISHCHUK; DAVYDOGLU, 2007). 
Manring e Hopkins (1958) foram os primeiros em sugerir uma abordagem empírica para o uso e controle dos agentes redutores e oxidantes com o propósito de predeterminar a sua eficácia no processo de fusão do vidro. Com base em experiências práticas a nível industrial eles atribuíram valores numéricos (números redox) para alguns agentes redutores/oxidantes utilizados pela indústria do vidro. Posteriormente Simpson e Myers (1978) e Manring e Diken (1980) atribuíram números redox para vários outros agentes redutores/oxidantes comumente usados na fabricação de vidro convencional. Um exemplo destes valores é apresentado na Tabela 2.10 (factores baseados em $1 \mathrm{~kg}$ de matériaprima por $2000 \mathrm{~kg}$ de areia na massa do vidro fundido).

Tabela 2.10 - Número redox de alguns agentes redutores e oxidantes usados na fabricação de vidros.

\begin{tabular}{cccc}
\hline Agentes redutores & Número redox & Agentes oxidantes & Número redox \\
\hline Sulfeto de calumite slag & $-9,00$ & $\mathrm{SO}_{3}$ & $+1,20$ \\
Carbono de calumite slag & $-6,70$ & Arsênico & $+0,93$ \\
Carbono $(100 \% \mathrm{C})$ & $-6,70$ & Dicromato de sódio & $+0,77$ \\
Coque $(85 \% \mathrm{C})$ & $-5,70$ & $\mathrm{Ca}_{2} \mathrm{SO}_{4}$ & $+0,70$ \\
Carbocite $(65 \% \mathrm{C})$ & $-4,36$ & $\mathrm{Na}_{2} \mathrm{SO}_{4}$ & $+0,67$ \\
Sulfeto ferroso & $-1,60$ & Dicromato de pótassio & $+0,65$ \\
Pirita de ferro & $-1,20$ & Gipsita & $+0,56$ \\
Mellite 40 & $-0,10$ & Barita & $+0,40$ \\
Cromita & $-1,00$ & Nitrato de sódio & $+0,15$ \\
Arsênico & $-0,93$ & & \\
\hline
\end{tabular}

Fonte: Simpson e Myers (1978)

No processo de fabricação de vidros verdes o estado de oxido-redução desempenha um papel de muita importância na obtenção da cor desejada. A relação entre as concentrações do ferro reduzido e o ferro total, $\mathrm{Fe}^{2+} / \mathrm{Fe}_{\text {total }}$, pode influenciar fortemente a cor final do vidro, como pode ser observado na Figura 2.12. Nesta figura são apresentados quatro vidros sodo-cálcicos com composições químicas similares, mas que apresentam cores diferentes. A variação de cor pode ser explicada pela relação $\mathrm{Fe}^{2+} / \mathrm{Fe}_{\text {total }}$. Por exemplo, quando o vidro é fabricado sob condições mais redutoras (até o valor da relação $\mathrm{Fe}^{2+} / \mathrm{Fe}_{\text {total }}$ exceder aproximadamente 0,4-0,5) a proporção $\mathrm{Fe}^{2+} / \mathrm{Fe}_{\text {total }}$ do vidro aumenta formando o cromóforo ${ }^{3}$ âmbar, $\mathrm{Fe}^{3+}-\mathrm{S}^{2-}$, o qual influencia a cor, resultando em uma cor verde marrom (verde oliva).

\footnotetext{
${ }^{3}$ Segundo a União Internacional de Química Pura e Aplicada (IUPAC), um cromóforo é a parte (átomo ou grupo de átomos) de uma molécula, que é responsável por una transição eletrônica numa determinada faixa espectral. O termo surgiu na indústria de tintas, referindo-se inicialmente aos grupos na molécula que são responsáveis pela cor de um corante.
} 
Figura 2.12 - Variação da cor em função da relação do estado de oxido-redução do ferro num vidro sodo-cálcico.

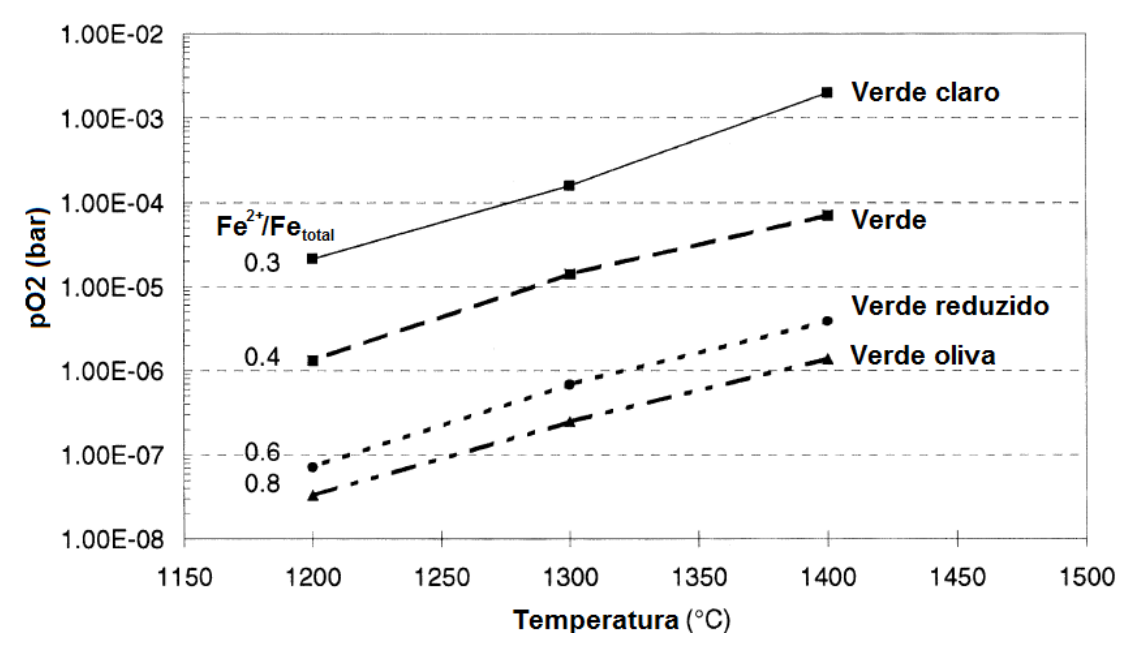

Fonte: Faber (2002)

\subsection{Cromo}

O químico francês Louis Valquelin descobriu o elemento cromo em 1797 quando estudava o mineral crocoíta, $\mathrm{PbCrO}_{4}$. O nome do elemento vem do grego, chroma que significa cor, e foi isolado em 1854, por Busen, porém este metal somente foi utilizado de modo mais intenso nas indústrias metalúrgica e de refratários a partir do século XX (SAMPAIO; ANDRADE; PAIVA, 2005).

O cromo $(\mathrm{Cr})$ é o vigésimo primeiro elemento mais abundante na crosta terrestre e o sexto metal de transição mais abundante depois do ferro, titânio, manganês, zircônio e vanádio, e mais abundante do que o níquel, zinco e cobre (CARDARELLI, 2008). O cromo existe principalmente em cinco estados de valência: cromo metálico $[\operatorname{Cr}(0)]$, cromo trivalente $[\mathrm{Cr}(\mathrm{III})]$, cromo bivalente $[\mathrm{Cr}(\mathrm{II})]$, cromo pentavalente $[\mathrm{Cr}(\mathrm{V})]$, e cromo hexavalente [ $\mathrm{Cr}(\mathrm{VI})]$ (ZADRA-STONE et al., 2007). O cromo ocorre naturalmente no meio ambiente principalmente na forma do mineral cromita $\left(\mathrm{FeCr}_{2} \mathrm{O}_{4}\right)$ com a presença de impurezas como o magnésio e alumínio (VITALE et al., 1997).

\subsubsection{Produção no Brasil e no mundo}

A cromita é o único mineral de cromo economicamente aproveitável. O cromo é encontrado em vários minerais nas formas de óxidos e silicatos e não há conhecimento da ocorrência de cromo metálico na natureza. Isso se deve ao caráter oxidante da atmosfera e a elevada reatividade do cromo metálico com o oxigênio. A composição teórica da cromita $\left(\mathrm{FeCr}_{2} \mathrm{O}_{4}\right)$ contém $68 \%$ de $\mathrm{Cr}_{2} \mathrm{O}_{3}$ e $32 \%$ de FeO. Entretanto, esses valores nunca 
são encontrados nos minerais naturais, em decorrência das impurezas. O magnésio e o alumínio estão presentes na estrutura da cromita, substituindo parcialmente o ferro (SAMPAIO; ANDRADE; PAIVA, 2005).

A produção mundial de cromita em 2012 foi de aproximadamente de 24,4 milhões de toneladas, destacando-se como países produtores a África do Sul, Cazaquistão e Índia. O Brasil, praticamente o único produtor de cromo no continente americano, continua com uma participação modesta, da ordem de $0,12 \%$ das reservas e de $1,9 \%$ da oferta mundial de cromita (RAMOS, 2013). Na Tabela 2.11 são apresentados os principais produtores de cromita no mundo e suas respectivas reservas. As principais reservas brasileiras de cromita estão localizadas nos estados da Bahia (84,0\%), Amapá (12,0\%) e Minas Gerais $(4,0 \%)($ RAMOS, 2010). O valor da tonelada de cromita no mercado internacional varia dependendo do conteúdo de $\mathrm{Cr}_{2} \mathrm{O}_{3}$ no concentrado, o preço médio de um concentrado com teor médio de 45,17\% de $\mathrm{Cr}_{2} \mathrm{O}_{3}$ registrado no ano de 2012 foi de 294,66 US\$/t-FOB (RAMOS, 2013).

Tabela 2.11 - Reservas e principais produtores de cromita no mundo no ano de 2012.

\begin{tabular}{lccc}
\hline Países & $\begin{array}{c}\text { Reservas } \\
\left(10^{3} \mathrm{t}\right)\end{array}$ & $\begin{array}{c}\text { Produção } \\
\left(10^{3} \mathrm{t} / \mathrm{ano}\right)\end{array}$ & $\begin{array}{c}\text { Porcentagem } \\
(\%)\end{array}$ \\
\hline Brasil & 464 & 472 & 1,9 \\
África do Sul & 200.000 & 11.000 & 45,1 \\
Cazaquistão & 210.000 & 3.800 & 15,6 \\
Índia & 54.000 & 3.800 & 15,6 \\
Outros Países & nd & 5.300 & 21,7 \\
Total & $>465.184$ & 24.372 & 100,0 \\
\hline
\end{tabular}

Fonte: Ramos (2013)

\subsubsection{Usos e funções}

O cromo destaca-se como o quinto elemento metálico mais abundante da crosta terrestre após o ferro, manganês, alumínio e cobre. Ainda assim, o homem só veio usar a cromita como fonte de cromo no final do século XVIII, primeiro, como pigmento e, mais tarde, como fixador de cor na indústria têxtil. No início do século XIX descobriu-se que o cromo confere propriedades inoxidáveis às ligas de aço. Mesmo assim, tal propriedade só foi posta em prática na segunda metade daquele século. Com o crescimento da indústria metalúrgica no início de século $\mathrm{XX}$, a cromita e outros minerais tornaram-se importantes "commodities" e, mais ainda, com a difusão dos aços inoxidáveis, fez do cromo um produto vital na indústria metalúrgica (SAMPAIO; ANDRADE; PAIVA, 2005). 
O cromo é utilizado em dezenas de processos industriais para criação de milhares de produtos de consumo. O cromo é usado na fabricação de aço inoxidável, numerosas ligas metálicas, revestimentos, pigmentos, catalisadores, tintura, curtimento, impregnação da madeira, tijolos refratários, fitas magnéticas, e muito mais. Até o início de 1900, a $\mathrm{FeCr}_{2} \mathrm{O}_{4}$ foi utilizada principalmente na fabricação de produtos químicos. Após 1900, a $\mathrm{FeCr}_{2} \mathrm{O}_{4}$ se tornou amplamente utilizada na fabricação de produtos metalúrgicos e refratários, principalmente na produção de aços inoxidáveis e tijolos refratários básicos (JACOBS; TESTA, 2005).

Os principais segmentos consumidores de cromo são as indústrias de aço e de ferroligas, química e de refratários. A indústria metalúrgica absorve $94 \%$ da produção global de cromita na produção de ligas de ferro-cromo, essencial para a produção de alço inoxidável e ligas especiais. O cromo não tem substituto na fabricação de aços inoxidáveis ou na produção de superligas. Por outro lado, os substitutos para fabricação de ligas, de produtos químicos e produtos refratários são geralmente de custos mais elevados e de aplicações limitadas (LIMA, 2009).

\subsubsection{O cromo na indústria de couro}

A descoberta do cromo como agente de curtume é atribuída ao químico alemão Friedrich Ludwing Knapp em 1858 (CAMERON; MCLAUGHLIN, 1937). Desde então, o cromo tem se tornado indispensável no processamento de transformação de pele em couro. Hoje em dia, o curtimento mineral de peles usando sais de cromo constitui o método mais amplamente utilizado nos processos de grande escala no mundo, segundo Sundar, Rao e Muralidharan (2002) mas do $90 \%$ da produção mundial de couro é realizada através do curtimento ao cromo.

O processo de curtimento ao cromo é o método mais empregado devido principalmente ás vantagens no processamento e a qualidade do produto final. Ou seja, o curtimento ao cromo é relativamente barato, age rapidamente e produz couro com propriedades físicas e químicas comercialmente atrativas (maciez, flexibilidade, resistência térmica, resistência à luz e excelentes propriedades de tingimento) em comparação com os processos de curtimento que utilizam taninos ${ }^{4}$ vegetais e sintéticos.

\footnotetext{
${ }^{4}$ Tanino é o termo utilizado para designar uma ampla variedade de compostos polifenólicos extraídos de vegetais, que tendem a formar complexos insolúveis com proteínas, alcalóides e metais (MATSUGO; MIZUNO; KONISHI, 1995).
} 


\subsubsection{Toxicologia do cromo}

O nível de toxicidade do cromo dependente da espécie química em que este encontra, o $\mathrm{Cr}$ (III) é relativamente não tóxico e é conhecido como um nutriente essencial para o ser humano, servindo como um co-fator da insulina, potencializando seu efeito e contribuindo com o metabolismo de glicose e lipídios (MILLER-IHLI, 1992; ZADRA-STONE et al., 2007).

Segundo o Conselho Nacional de Pesquisa (NRC) dos Estados Unidos, os aportes recomendados de $\operatorname{Cr}($ III) para adultos são de 50 a $200 \mu \mathrm{g}$ diários. As concentrações de cromo nos fluidos corporais de adultos normais saudáveis são geralmente inferiores a 1 $\mathrm{ng} / \mathrm{mL}$ (MILLER-IHLI, 1992). É importante mencionar também que a forma trivalente de $\mathrm{Cr}$ é 500-1000 vezes menos tóxica do que a forma hexavalente (LANGARD; COSTA, 2007).

$\mathrm{O} \mathrm{Cr}(\mathrm{VI})$ é amplamente conhecido como agente alérgico, causando dermatites. Pode também causar sensibilização pulmonar e aumentar a incidência de câncer de pulmão, o que ocorre usualmente somente após um longo período de exposição (FUNDACENTRO, 2012). Os compostos contendo $\mathrm{Cr}(\mathrm{VI})$ são classificados nas categorias de agente carcinogênicos para humanos por várias organizações internacionais, tais como a Agência Internacional para Pesquisa sobre Câncer (IARC) e a Agência de Proteção Ambiental dos Estados Unidos (U.S. EPA), organizações nas quais estes compostos são classificados no Grupo 1 e Grupo A, respectivamente (QINGDONG-KE; MAX, 2007).

Os compostos de cromo a seguir são os mais comuns no meio ambiente e os que apresentam maior risco para a saúde: compostos de espécies de $\mathrm{Cr}(\mathrm{VI})$, cromato de sódio $\left(\mathrm{Na}_{2} \mathrm{CrO}_{4}\right)$ e dicromato de sódio $\left(\mathrm{Na}_{2} \mathrm{Cr}_{2} \mathrm{O}_{7} \cdot 2 \mathrm{H}_{2} \mathrm{O}\right)$, cromato de cálcio $\left(\mathrm{CaCrO}_{4} \cdot 2 \mathrm{H}_{2} \mathrm{O}\right)$, pigmentos a base de cromatos de zinco e chumbo, e ácido crômico. Espécies de Cr(III) e cromo elementar, $\mathrm{Cr}(0)$, muitas vezes encontradas pelos trabalhadores industriais incluem cromita $\left(\mathrm{FeCr}_{2} \mathrm{O}_{3}\right)$ e cromita de cálcio $\left(\mathrm{CaCr}_{2} \mathrm{O}_{3}\right)$, óxido de cromo $\left(\mathrm{Cr}_{2} \mathrm{O}_{3}\right)$, sulfatos básicos de cromo, cromo metálico e ligas metálicas (MILLER-IHLI, 1992).

A população em geral pode ser exposta a cromo através da inalação de ar do ambiente, ingestão de água, ou contato com a pele com produtos que contêm compostos de cromo principalmente $\mathrm{Cr}(\mathrm{VI})$. Pessoas que vivem perto de instalações industriais que utilizam o $\mathrm{Cr}(\mathrm{VI})$ ou perto de aterros sanitários têm o maior potencial de exposição (HHS, 2011). Os efeitos da exposição a compostos de $\mathrm{Cr}(\mathrm{VI})$ podem ser categorizados como cancerígenos e não cancerígenos e dependendo do tempo de exposição estes podem ser: agudos (14 dias ou menos), intermediários (15 a 364 dias) e crônicos (265 dias ou mais) (GUERTIN, 2005). 


\subsubsection{Ingestão}

A ingestão de cromo ocorre comumente através do consumo de alimentos, água potável e ingestão de solos contaminados (principalmente por crianças). Da quantidade total de cromo ingerido apenas de $2 \%$ a $3 \%$ é absorvido pelo sistema digestivo. $\mathrm{Cr}(\mathrm{VI})$ é rapidamente reduzido para $\mathrm{Cr}$ (III) pelos sucos gástricos (GUERTIN, 2005).

É claro que a ingestão de $\mathrm{Cr}(\mathrm{VI})$ pode causar doenças e morte em última instância. Ingestão de $\mathrm{Cr}(\mathrm{VI})$, muitas vezes, produz queimaduras e hemorragia gastrointestinal, danos no fígado, aos rins e danos que podem levar à morte. Outros sintomas são diarreia, úlceras, dor abdominal, indigestão e vômitos. Outros estudos têm reportado redução na produção de esperma e efeitos negativos durante a gestação (anormalidades grosseiras e diminuição da massa fetal).

\subsubsection{Contato cutâneo}

A exposição do cromo com a pele ocorre normalmente em trabalhadores de indústrias que utilizam cromo nos seus processos. No entanto, modos menos comuns de exposição podem ocorrer em piscinas, chuveiros e em contato com solos contaminados. Trabalhadores na indústria do cromo (revestimento e fabricação de produtos químicos) são susceptíveis de experimentar algum grau de exposição cutânea a $\mathrm{Cr}(\mathrm{VI})$, seja por contato com poeira contaminada na pele ou pelo contato da pele com líquidos contendo $\mathrm{Cr}(\mathrm{VI})$. Devido ao fato do $\mathrm{Cr}(\mathrm{VI})$ ser geralmente muito mais solúvel em água do que os compostos de $\mathrm{Cr}(\mathrm{III})$, o $\mathrm{Cr}(\mathrm{VI})$ pode penetrar a pele 10000 vezes mais rápido que o $\mathrm{Cr}(\mathrm{III}), 5 \times 10^{-11} \mathrm{~cm} / \mathrm{s}$ contra $5 \times 10^{-7} \mathrm{~cm} / \mathrm{s}$, respectivamente. No entanto, se a exposição ocorrer numa lesão na pele a taxa de penetração é praticamente idêntica (GUERTIN, 2005).

Compostos de $\mathrm{Cr}(\mathrm{VI})$ tais como o $\mathrm{CrO}_{3}$ (e o correspondente ácido crômico, $\mathrm{H}_{2} \mathrm{CrO}_{3}$ ), $\mathrm{K}_{2} \mathrm{Cr}_{2} \mathrm{O}_{7}, \mathrm{~K}_{2} \mathrm{CrO}_{4}, \mathrm{Na}_{2} \mathrm{Cr}_{2} \mathrm{O}_{7}$ e $\mathrm{Na}_{2} \mathrm{CrO}_{4}$ são muito corrosivos e podem queimar gravemente a pele. Tais queimaduras facilitam absorção do $\mathrm{Cr}(\mathrm{VI})$ através da pele potencializando sua toxicidade. Contato de compostos de $\mathrm{Cr}(\mathrm{VI})$ pode causar necrose cutânea, formação de escaras (crosta), diarreia, edema dérmico e eritema (vermelhidão excessiva).

\subsubsection{Inalação}

A inalação de cromo ocorre por exposição a ambientes que contém partículas sólidas ou partículas dissolvidas em água (poeira, fumaça, aerossol). A inalação de $\mathrm{Cr}(\mathrm{VI})$ e $\operatorname{Cr}(I I I)$ têm efeitos na saúde completamente diferentes. Por exemplo, a inalação de 
$\mathrm{Cr}(\mathrm{VI})$ como óxido hexavalente $\left(\mathrm{CrO}_{3}\right)$ provoca dano e irritação nasal já o inalação de $\mathrm{Cr}(\mathrm{III})$ não produze nem dano nem irritação nasal. Além disso, $\mathrm{Cr}(\mathrm{VI})$, devido à sua maior solubilidade em água, é absorvido mais rapidamente nos pulmões do que $\mathrm{Cr}$ (III). Aproximadamente de $53 \%$ a $85 \%$ do $\mathrm{Cr}(\mathrm{VI})$ inalado é eliminado pelos pulmões por absorção para a corrente sanguínea ou por mucosas da faringe. No entanto de $15 \%$ a $47 \%$ do $\mathrm{Cr}(\mathrm{VI})$ permanece no pulmão. Sendo este fenômeno o principal contribuinte para toxicidade do $\mathrm{Cr}(\mathrm{VI})$, especialmente para o câncer (GUERTIN, 2005).

Estudos epidemiológicos realizados em trabalhadores expostos a ambientes com cromo têm claramente estabelecido que o cromo é um carcinógeno humano apenas por inalação, causando um aumento do risco de câncer de pulmão. No entanto, nestes estudos os trabalhadores foram expostos tanto a compostos de $\mathrm{Cr}$ (III) quanto a compostos de $\mathrm{Cr}(\mathrm{VI})$. Outro estudos realizados em animais tem identificado somente o $\mathrm{Cr}(\mathrm{VI})$ como agente cancerígeno. Deste modo a U.S. EPA concluiu que apenas o $\mathrm{Cr}(\mathrm{VI})$ deve ser classificado como um carcinógeno humano.

Como mencionado anteriormente, a U.S. EPA classifica os compostos contendo $\mathrm{Cr}(\mathrm{VI})$ no Grupo A, carcinógeno humano definido por inalação, estabelecendo um risco unitário de inalação de $0,012 \mu \mathrm{g} / \mathrm{m}^{3}$. Na Tabela 2.12 são apresentados os limites de referência para compostos de $\mathrm{Cr}(\mathrm{III})$ e $\mathrm{Cr}(\mathrm{VI})$, estabelecidos pela U.S. EPA.

Tabela 2.12 - Limites de referência para compostos de $\mathrm{Cr}(\mathrm{III})$ e $\mathrm{Cr}(\mathrm{VI})$, estabelecidos pela U.S. EPA.

\begin{tabular}{|c|c|c|c|}
\hline \multirow{2}{*}{$\begin{array}{l}\text { Espécie } \\
\text { de cromo }\end{array}$} & \multirow{2}{*}{$\begin{array}{l}\text { Efeitos cancerígenos } \\
\text { Inalação (UR) }{ }^{6}\end{array}$} & \multicolumn{2}{|c|}{ Efeitos não cancerígenos } \\
\hline & & ingestão (RfD) ${ }^{5}$ & inalação $(\mathrm{RfC})^{5}$ \\
\hline $\mathrm{Cr}(\mathrm{III})$ & não estabelecido & $1,5 \mathrm{mg} / \mathrm{kg}$-dia & não estabelecido \\
\hline $\mathrm{Cr}(\mathrm{VI})$ & $0,012 \mu \mathrm{g} / \mathrm{m}^{3}$ & $0,003 \mathrm{mg} / \mathrm{kg}$-dia & $\begin{array}{c}0,0001 \mathrm{mg} / \mathrm{m}^{3} \\
\text { (partículas) } \\
0,000008 \mathrm{mg} / \mathrm{m}^{3} \\
\text { (fumaça de ácido } \\
\text { crômico e aerossóis) }\end{array}$ \\
\hline
\end{tabular}

Fonte: U.S. EPA

\footnotetext{
${ }^{5} \mathrm{RfD}$ e RfC, refere-se à dose (oral) e a concentração (inalação) respectivamente, a qual a população pode ser exposta diariamente, sem risco de efeitos nocivos durante toda a vida.

${ }^{6}$ UR (fator unitário de risco), refere-se à probabilidade de desenvolver câncer como resultado da exposição contínua a um agente nocivo em uma concentração de $1 \mu \mathrm{g} / \mathrm{L}$ em água, ou $1 \mu \mathrm{g} / \mathrm{m}^{3}$ no ar. A interpretação do risco unitário de inalação seria a seguinte: se o risco unitário $=2 \times 10^{-6}$ por $\mu \mathrm{g} / \mathrm{L}, 2 \mathrm{de}$ cada 1.000.000 pessoas (no máximo) deverão desenvolver câncer, se forem expostas diariamente por uma vida inteira a 1 micrograma da substância química em um metro cúbico de ar.
} 


\subsection{Indústria de couro}

O Brasil é o segundo maior produtor de couro cru no mundo, superado apenas pela China e à frente da Índia e dos Estados Unidos. No Brasil, os principais produtores encontram-se nos estados de São Paulo, Rio Grande do Sul, Paraná e Ceará. A indústria de produção de couro é considerada um dos grandes motores da economia brasileira, segundo dados do CICB. Estima-se que a cadeia produtiva do couro que abrange os setores de curtumes, calçados, componentes, máquinas e equipamentos para artigos em couro, reúne por volta de 10 mil indústrias, emprega mais de 500 mil pessoas e movimenta aproximadamente 21 bilhões de dólares por ano (TAVARES, 2011).

No Brasil existem cerca de 2000 indústrias processadoras de couros distribuídas entre curtumes e acabadoras, e mais de 5000 fábricas de calçados e de artefatos, cujas matérias-primas são respectivamente as peles em estado fresco ou salgado; couros em estado "wet-blue"7 ou "wet-white"8; e couros em estado semi-acabados e acabados (CULTRI; MANFRINATO; RENÓFIO, 2006).

De acordo com os dados do CICB, as exportações brasileiras de couros e peles, em 2013, foram aproximadamente de 35 milhões de peças de couro (salgado, "wet-blue", semi-acabado e/ou couro acabado) somando ao redor de 2,5 US\$ bilhões. O acumulado de 2013 foi também o maior já registrado, mostrando um aumento de 20,8\% em relação a 2012 (CICB, 2013). Nos últimos anos, a indústria de produção de couro tem se firmado na economia brasileira e se encontra em franco crescimento. O setor do couro representa mais de $14 \%$ da balança comercial brasileira (CICB-APEXBRASIL, 2013).

Os principais destinos dos couros brasileiros entre janeiro e dezembro de 2013 foram, a China com $36,3 \%$, Itália com $20,5 \%$ e Estados Unidos com 10,0\% (CICB, 2013). Entre os principais estados exportadores de couros e peles o Rio Grande do Sul ocupa a primeira posição, com 20,2\%, seguido de São Paulo, com 19,9\%. Em seguida está Goiás com $12,5 \%$, Paraná com $11,5 \%$, Ceará com 7,7\%, Mato Grosso do Sul com 6,5\% e Bahia com $5,2 \%$ (CICB, 2013).

\footnotetext{
7"Wet-blue" é o termo técnico, de origem inglesa, utilizado para designar o couro produzido no processo inicial de curtimento ao cromo. Esta denominação origina-se devido ao aspecto que o couro curtido apresenta, ou seja, úmido e com coloração azul (dados técnicos fornecidos pela Associação dos Manufatores de Couros e Afins do Distrito Industrial de Franca - AMCOA, em julho de 2012).

8"Wet-white" é o termo utilizado para designar o couro livre de cromo, curtido utilizando sais de alumínio ou glutaraldeídos (PÜNTENER et al., 2004).
} 


\subsection{Processo de produção de couro}

O processo de transformação da pele em couro envolve uma ampla série de etapas físicas e químicas nas quais são utilizadas grandes quantidades de água e diferentes reagentes químicos, gerando assim uma grande quantidade de resíduos sólidos, líquidos e gasosos. Nos últimos anos, devido à crescente preocupação ambiental, as indústrias de produção de couro têm adotado algumas práticas e tecnologias alternativas menos poluidoras, com o objetivo de otimizar o aproveitamento das matérias-primas, água, insumos químicos e minimizar a geração de resíduos. Mesmo assim, o processo de transformação de peles em couros não apresenta grandes variações podendo ser descrito em três etapas principais, conhecidas por ribeira, curtimento e acabamento (PACHECO, 2005). Na Figura 2.13 ilustra-se de forma resumida as operações realizadas durante as três etapas principais do processo de beneficiamento do couro.

Figura 2.13 - Diagrama do processo de beneficiamento do couro.

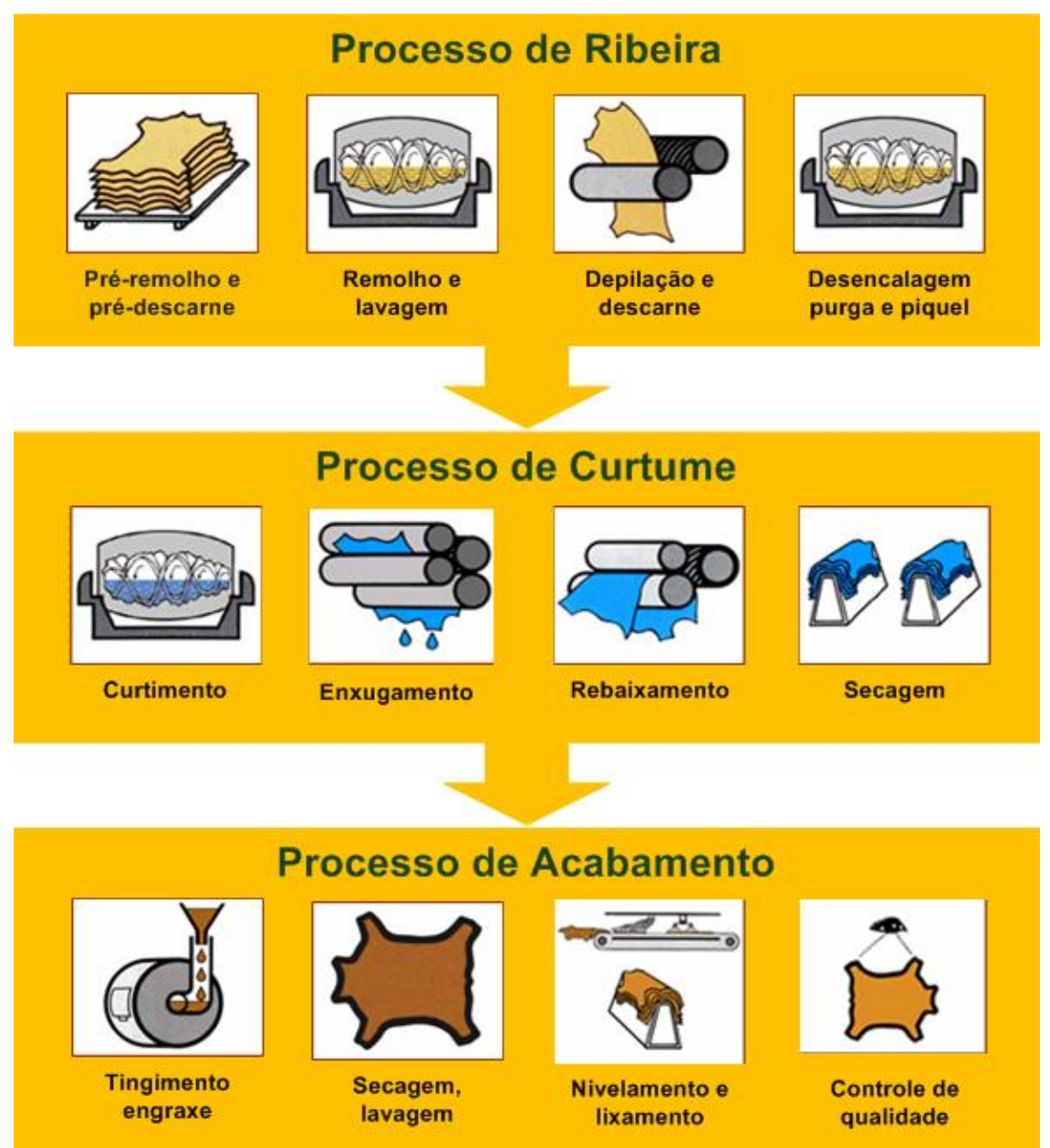

Fonte: elaborado pelo autor utilizando as imagens do site http://www.alltrends.com.sg. 


\subsubsection{Ribeira}

Esta etapa tem por finalidades a limpeza e a eliminação das diferentes partes e substâncias das peles (pêlos, carne e gorduras aderidas à pele) que não irão constituir os produtos finais (couros), bem como preparar sua matriz de fibras colagênicas, para reagir adequadamente com os produtos químicos das etapas seguintes, o curtimento e o acabamento (PACHECO, 2005).

\subsubsection{Curtimento}

O curtimento é um processo que consiste na transformação das peles, pré-tratadas na ribeira, em materiais estáveis e imputrescíveis, ou seja, a transformação das peles em couros. Pode ser classificado em três tipos principais: mineral, vegetal e sintético (PACHECO, 2005).

Curtimento mineral: O processo ao cromo ainda é o principal processo de curtimento, utilizado mundialmente, devido principalmente ao tempo relativamente curto de processamento e pela qualidade que confere aos couros em suas principais aplicações. A fonte de cromo normalmente utilizada é o sulfato básico de cromo $\left(\mathrm{Cr}(\mathrm{OH}) \mathrm{SO}_{4}\right)$, onde este se encontra no estado trivalente. No entanto, esforços crescentes para sua substituição são verificados, devido ao seu impacto ambiental potencialmente negativo.

Curtimento vegetal: É realizado empregando taninos contidos em extratos vegetais e é geralmente utilizado, em combinação com os outros tipos de curtimento, para a produção de solas e de alguns tipos especias de couro. Devido ao seu alto custo, os taninos são utilizados tentando-se aproveitar ao máximo suas propriedades. $\mathrm{Na}$ maioria das vezes, faz-se apenas a reposição de solução para o lote de peles seguinte, para compensar a parte absorvida pelas peles do lote anterior. Com o aumento do uso de materiais sintéticos na fabricação de solas, o curtimento vegetal de couro para este fim diminuiu significativamente.

Curtimento sintético: É realizado empregando curtentes sintéticos, em geral orgânicos (resinas e taninos sintéticos, por exemplo), que proporcionam um curtimento mais uniforme e aumentam a penetração de outros curtentes, como os taninos e outros produtos. Este curtimento propicia por exemplo, um melhor tingimento posterior. Geralmente, são relativamente mais caros que os outros curtentes e são mais usados como auxiliares de curtimento. 


\subsubsection{Acabamento}

As operações posteriores ao curtimento são denominadas operações de acabamento. Nesta etapa se confere as características finais necessárias ao couro, de acordo com a sua aplicação. Esta etapa tem por objetivo igualar e definir a espessura do couro, conferir flexibilidade, impermeabilidade, cor e toque macio ao couro, atenuar defeitos e finalmente prensar, medir e uniformizar o contorno do couro para posterior comercialização (PACHECO, 2005; STREIT, 2006).

\subsection{Tipos de curtume}

Os curtumes podem ser classificados em função das etapas que são realizadas no seus processos de fabricação. A seguir são apresentados de forma resumida alguns dos principais processos de curtimento utilizados na indústria, os fluxogramas detalhados de cada tipo curtume, fornecidos pela AMCOA, são apresentados no anexo A.

\subsubsection{Curtume produtor de "wet-blue"}

Compreende o curtume que realiza o processamento desde peles cruas, (qualquer que seja o estado de conservação da pele) até a etapa de curtimento ao cromo e seu produto é comumente denominado de couro no estágio "wet-blue".

\subsubsection{Curtume produtor de semi-acabado}

Compreende o curtume que realiza o processamento desde peles cruas (qualquer que seja o estado de conservação da pele), passando pelas etapas de curtimento ao cromo, recurtimento, tingimento, engraxe e secado, e seu produto é comumente denominado de couro no estágio semi-acabado ou "crust". Esta denominação decorre do fato de que a este couro falta apenas a pintura final para estar pronto aos usos diversos.

\subsubsection{Curtume de processamento completo}

Conhecido também como curtume integrado, trata-se do curtume que realiza o processamento completo desde peles cruas (qualquer que seja o estado de conservação da pele) até couro acabado curtido ao cromo. 


\subsubsection{Curtume de acabamento}

\subsubsection{Acabadora de couro a partir de "wet-blue" até acabado}

É o tipo de curtume que trabalha matéria prima já semi-processada, a partir do estágio "wet-blue", até couro acabado, pronto para usos diversos.

\subsubsection{Acabadora de couro a partir de semi-acabado até acabado}

Curtume que trabalha matéria prima semi processada, no estágio semi-acabado, até couro acabado, pronto para usos diversos.

\subsection{Resíduos sólidos gerados no processo de transfor- mação do couro}

Como já foi mencionado anteriormente, durante o processo de transformação de pele em couro são geradas grandes quantidades de resíduos sólidos, líquidos e gasosos. Estes resíduos são gerados em diferentes etapas deste processo industrial e dependendo das suas características podem representar um potencial risco à saúde pública e ao meio ambiente. Na Figura 2.14 são apresentados os principais resíduos gerados em cada etapa do processo de beneficiamento do couro.

Segundo Pacheco (2005) do processamento convencional de $1000 \mathrm{~kg}$ de peles salgadas, somente de 200 a $250 \mathrm{~kg}$ das matérias-primas são transformadas em couro, e aproximadamente $600 \mathrm{~kg}$ são resíduos sólidos, o que representa um baixo rendimento médio, em torno de $22,5 \%$, e um alto potencial poluidor. Segundo Cultri, Manfrinato e Renófio (2006) o setor coureiro no Brasil é responsável pela geração em média de 1400 toneladas de resíduos por dia. Os resíduos sólidos gerados no processamento de couro podem ser agrupados em duas categorias (ALVES; BARBOSA; RENOFIO, 2009).

Resíduos sólidos não curtidos: Constituem os resíduos provenientes da pele bruta e do descarne e divisão, são as aparas caleadas e não caleadas, carnaça e demais resíduos gerados na operação de ribeira. Estes resíduos são classificados como não perigosos e são ricos em colágeno e gorduras. Podem ser transformados em cola e gelatina dentre outros produtos. 
Resíduos sólidos curtidos: Constituem os resíduos provenientes das ETEs (lodos contaminados com cromo), da etapa de acabamento molhado, rebaixamento e recorte (compreendem: rebarbas, serragem, farelos, raspas e aparas de couro curtido) e lixamento (pó de lixadeira). Estes resíduos são classificados pela legislação brasileira (ABNT NBR 10004) como materiais perigosos (Resíduos classe I) de características tóxicas devido a seu conteúdo de $\mathrm{Cr}(\mathrm{VI})$. De acordo com o anexo B da NBR 10004 as aparas, pó de rebaixadeira e lodos das ETEs são identificadas, respectivamente, com os códigos K193, k194 e k195.

Figura 2.14 - Principais resíduos gerados em cada etapa do processo de beneficiamento do couro.

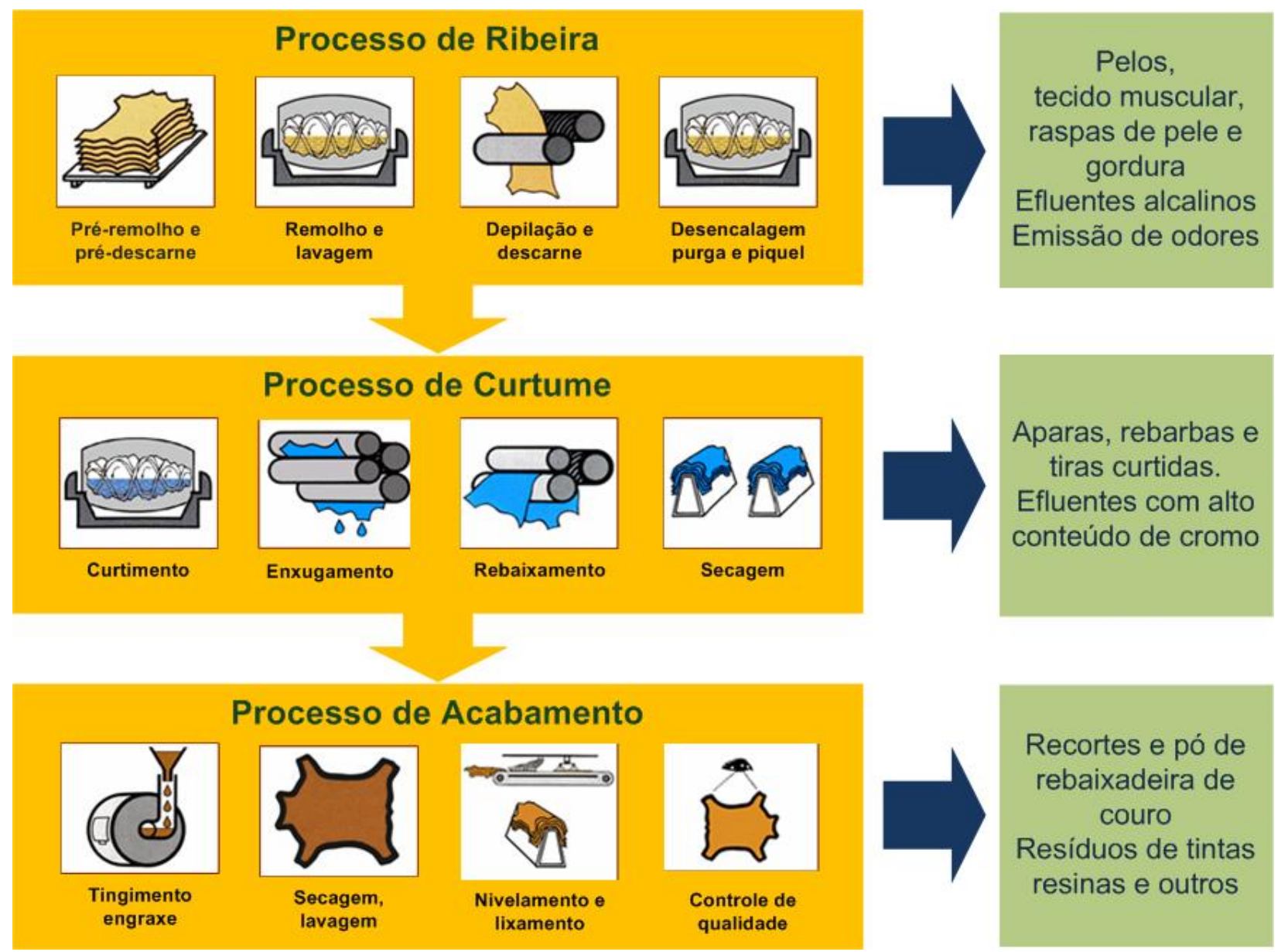

Fonte: elaborado pelo autor utilizando as imagens do site http://www.alltrends.com.sg.

Os resíduos sólidos curtidos (resíduos que contêm cromo) destacam-se dentre todos os resíduos sólidos gerados pela indústria de curtume devido a sua potencial periculosidade, reatividade e toxicidade. Estes resíduos possuem um considerável conteúdo de $\mathrm{Cr}(\mathrm{III})$, o qual, sob condições oxidantes, pode transformar-se em $\operatorname{Cr}(\mathrm{VI})$, que é altamente tóxico para plantas, animais e seres humanos (LANGARD; COSTA, 2007). 
Os resíduos curtidos (pó de rebaixadeira e aparas de couro), apresentam teores de $\mathrm{Cr}(\mathrm{III})$ de 2 a 3\% (base seca) e são relativamente resistentes à degradação natural no meio ambiente. Já os lodos provenientes das ETEs contém teores significativos de $\mathrm{Cr}$ (III), até 1\% (base seca) alem de outros poluentes (PACHECO, 2005). A disposição dos resíduos sólidos curtidos é realizada comumente em aterros sanitários classe I, sendo depositadas centenas de toneladas destes resíduos em aterros sanitários diariamente. Na Figura 2.15 ilustra-se de maneira resumida um esquema que mostra os principais resíduos curtidos gerados no processo de transformação de pele em couro.

Figura 2.15 - Resíduos sólidos curtidos gerados pela indústria de couro.

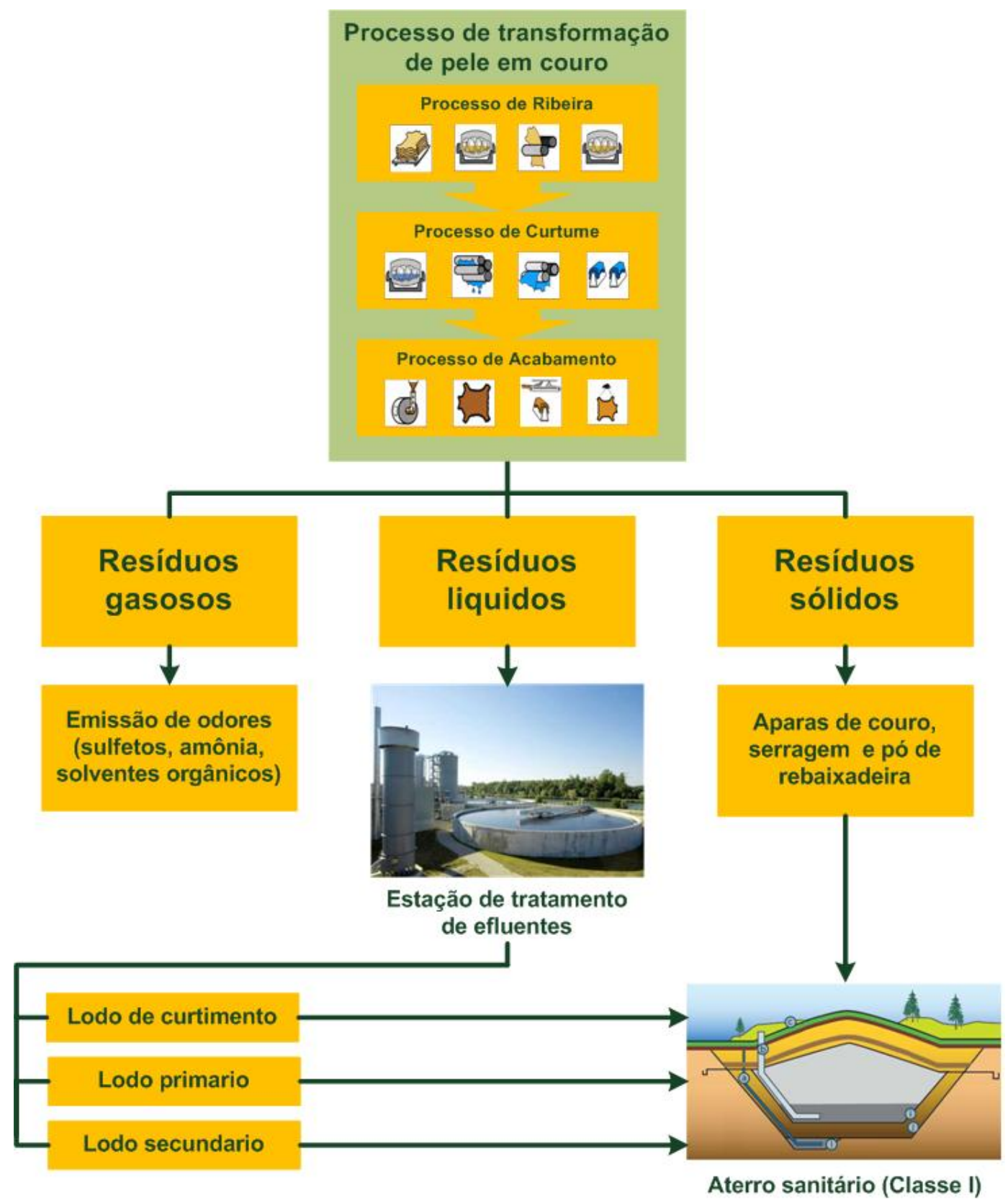

Fonte: Elaborado pelo autor utilizando imagens do site http://desleronline.com. 
Na região de São Paulo o principal polo coureiro se encontra localizado no município de Franca, o qual segundo Cultri, Manfrinato e Renófio (2006) responde apenas pela produção de 160 t/dia das 1400 t/dia geradas pela setor coureiro no Brasil. Segundo dados pela AMCOA, estima-se que sejam geradas ao redor de 20 t/dia de resíduos curtidos (serragem e aparas de couro), 20 t/dia de lodos primário e secundário provenientes das ETEs e $50 \mathrm{~kg} / \mathrm{dia}$ de lodos de curtimento, também conhecidos como lodos de cromo, provenientes do pré-tratamento dos efluentes da etapa de curtimento.

Os lodos contaminados com cromo são gerados em diferentes etapas do processamento de couro, e dependendo do tipo de curtume (curtume integrado, curtume de "wetblue", curtume de semi-acabado e curtume de acabamento) podem apresentar diferentes níveis de cromo em sua composição. Os lodos primários e secundários são produtos gerados durante o tratamento primário e secundário de efluentes nas ETEs e apresentam baixos teores de cromo. Por outro lado, os lodos de cromo provenientes do pré-tratamento dos banhos de curtimento e recurtimento apresentam teores significativos de cromo. $\mathrm{Na}$ Figura 2.16 é apresentado um fluxograma simplificado dos tipos de lodos gerados durante as etapas de tratamento de efluentes.

Figura 2.16 - Etapas do tratamento de efluentes na indústria de produção de couro e os resíduos gerados durante estas etapas.

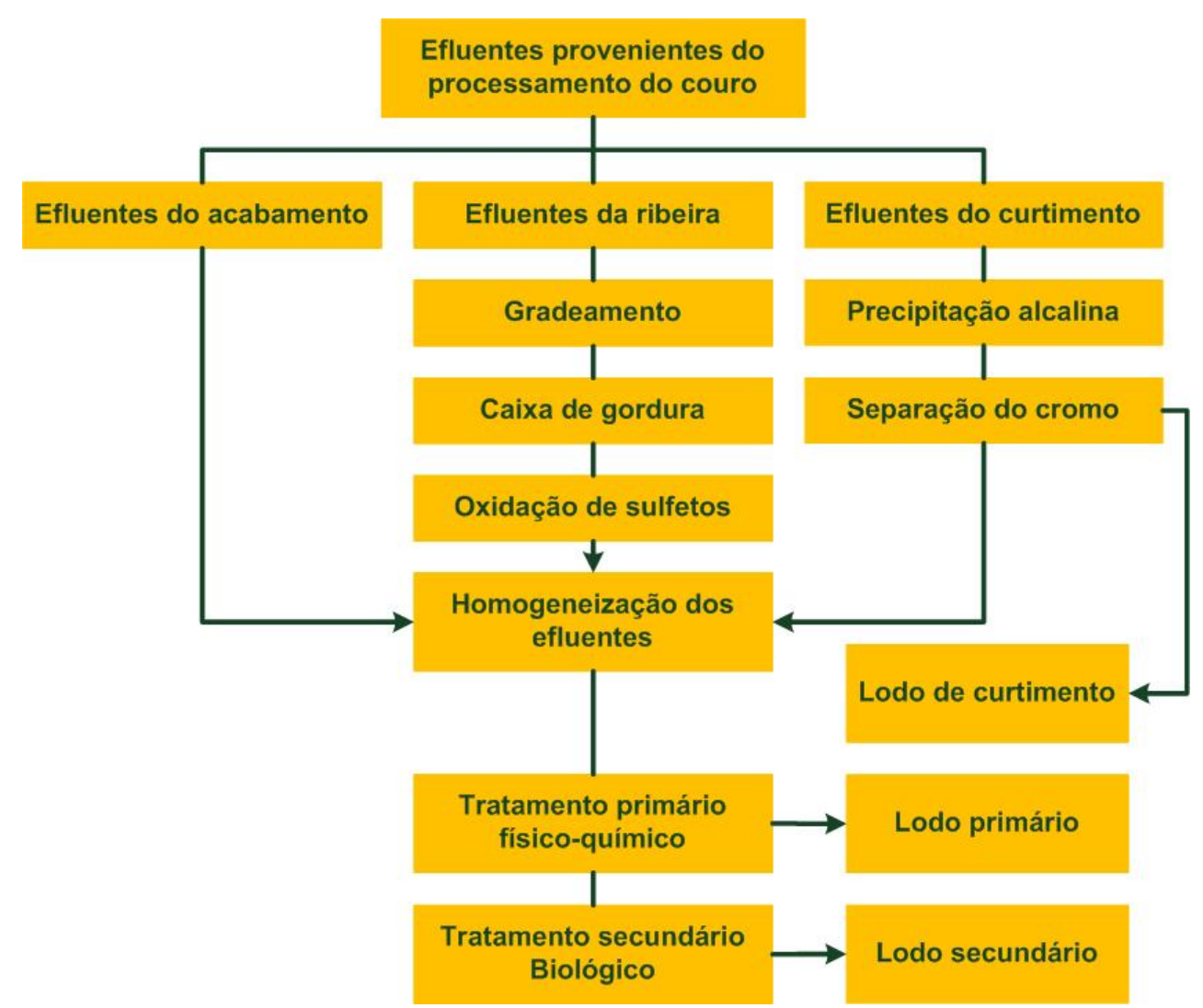

Fonte: adaptado do trabalho de Ananias e Pacca (2009). 


\subsection{Destinação dos resíduos sólidos da indústria de couro: estado da arte}

Na última década, com o aumento dos índices de contaminação no mundo, as normas legais a respeito do tratamento de resíduos têm se tornado cada vez muito mais rigorosas. Este comportamento tem levado as diversas indústrias geradoras de resíduos a adotar práticas da produção mais limpa nos seus processos produtivos. A indústria de produção de couro não é a exceção. Considerada uma indústria altamente poluente, esta atividade gera grandes quantidades de resíduos sólidos, líquidos e gasosos diariamente.

As características poluentes dos resíduos sólidos provenientes da indústria de couro, são atribuídas principalmente ao uso de sais de cromo durante a etapa de curtimento, considerada uma etapa essencial no processo de transformação de pele em couro. Como solução a este problema, vários estudos têm sido realizados com o propósito de otimizar e procurar tecnologias alternativas no processamento dos couros. Estes estudos têm-se focado principalmente na utilização de taninos alternativos (SARAVANABHAVAN et al., 2004; SHAO et al., 2008; SREERAM; RAMASAMI, 2003), substituição parcial do cromo (processo com menos cromo) (CIAMBELLI et al., 2005; MANDAL et al., 1983; SUPARNO et al., 2005; WENZEL et al., 2010), otimização dos níveis de absorção do cromo nos banhos de curtimento (redução da descarga de resíduos) (BACARDIT et al., 2008; MÃNTYSALO; MARJONIEMI; KILPELÃINEN, 1997; MORERA et al., 2011; SURESH et al., 2001) e na recuperação e reutilização do cromo no processo de curtimento (ERDEM, 2006; GUO et al., 2006; HERMES et al., 2009; KANAGARAJ; BABU; MANDAL, 2008; RODRIGUES et al., 2008; SCHOLZ; LUCAS, 2003). Algumas destas tecnologias têm sido adotas nos processos comerciais de transformação de couro, enquanto outras estão em seus estágios iniciais de desenvolvimento.

Embora a estabilização de couro utilizando agentes curtentes alternativos (taninos minerais e orgânicos) seja conhecida há várias décadas, muitas limitações têm sido reconhecidas para o uso generalizado destes materiais nos processos industriais de transformação de couro (SREERAM; RAMASAMI, 2003). Neste sentido a substituição total do cromo no processo de curtimento é ainda uma alternativa inviável. De acordo com a Comissão Econômica e Social para a Ásia e o Pacífico (UNESCAP) as alternativas mais realistas e economicamente viáveis para reduzir o uso do cromo no processo de curtume são a implementação de sistemas de alta exaustão que permitem aumentar os níveis de fixação de cromo durante o curtimento e a recuperação e reúso de cromo por precipitação (GUPTA, 2001). 
Durante os últimos anos, as indústrias brasileiras de produção de couro têm adotado varias práticas e tecnologias alternativas menos poluidoras, com o objetivo de otimizar o aproveitamento das matérias-primas, água, insumos químicos e minimizar a geração de resíduos. No entanto, a disposição das grandes quantidades de resíduos sólidos gerados no processo de transformação de pele em couro continua sendo um problema sério, principalmente devido à potencial periculosidade, reatividade e toxicidade destes resíduos.

No Brasil a disposição final dos resíduos sólidos curtidos provenientes das indústrias de couro é normalmente realizada em aterros sanitários classe I. Já que esta representa uma alternativa relativamente barata. No entanto, devido às enormes quantidades de resíduos gerados nos processos de produção de couro, os custos de coleta e disposição final resultam relativamente altos. Além disso, a disposição em aterros sanitários não é considerado uma alternativa de gestão sustentável de resíduos. Portanto, é imperativo buscar alternativas viáveis para reduzir, reutilizar, reciclar ou recuperar estes resíduos.

Nos últimos anos, a incineração tem sido reconhecida como um método altamente eficaz de redução de resíduos se conduzido sob condições ótimas. A incineração controlada de resíduos destrói permanentemente compostos orgânicos tóxicos dentro dos resíduos, convertendo-os em moléculas estáveis, reduzindo o volume dos resíduos perigosos e produzindo um resíduo altamente concentrado contendo vários compostos inorgânicos (PICHTEL, 2005). Além disso, dependendo das características do resíduos, a incineração pode permitir a recuperação de calor que por sua vez pode ser convertida em eletricidade, água quente, etc.

No Brasil a incineração de resíduos sólidos da indústria coureiro-calçadista tem sido estudada amplamente por um grupo de pesquisadores do Departamento de Engenharia Química da Universidade Federal do Rio Grande do Sul (UFRGS). Como parte deste projeto foi montada uma planta piloto de incineração de pó de couro de curtumes e aparas da indústria de calçados localizada no município de Dois Irmãos, a 60 quilômetros de Porto Alegre, RS. Os diversos trabalhos realizados por este grupo de pesquisa têm chamado a atenção devido ao considerável teor de óxido de cromo que apresentam as cinzas da incineração e pó de couro de curtumes e aparas de couro, de entre 40 e 60\% em massa (PEREIRA, 2006; WENZEL, 2008; GODINHO, 2006). Esta característica as torna potenciais fontes de matéria-prima para indústria química, especialmente os curtumes, quanto a metalúrgica (ALVES; HECK; SCHNEIDER, 2009). No entanto, devido à sua potencial toxicidade a estabilidade dos íons cromo deve ser levada em consideração para qualquer aplicação. 
Segundo o trabalho realizado por Martins (2001) sobre o estudo das espécies de cromo nas cinzas de incineração de couro em reatores de leito fixo e leito fluidizado, o aumento de temperatura e de $\mathrm{pH}$, aliado à baixa umidade, favorecem a formação de $\mathrm{Cr}(\mathrm{VI})$. Foi demonstrado também que o processo de incineração usando o reator de leito fixo gera cinzas com menor teor de $\mathrm{Cr}(\mathrm{VI})$ devido à tecnologia de gaseificação e combustão combinadas que consiste basicamente na incineração em duas câmaras, uma de combustão incompleta (gaseificação) que gera um ambiente redutor e outra de combustão completa.

Dettmer et al. (2010b) estudaram a possibilidade de utilizar o cromo das cinzas da incineração de aparas de couro na produção de sulfato básico de cromo, obtido a partir de cromato de sódio por meio de processos químicos (DETTMER et al., 2010a), para ser reutilizado no processo de curtimento de peles. Os sais de cromo obtidos neste trabalho mostraram propriedades muito similares aos sais de cromo comerciais utilizados no processamento industrial de couro.

Outros autores estudaram a utilização das cinzas da incineração de aparas de couro como matéria-prima na produção de ferroligas de alto carbono (ALVES; HECK; SCHNEIDER, 2009) e na produção de sulfatos de ferro e cromo solúveis a partir de ferroligas obtidas por meio da redução carbotérmica (WENZEL et al., 2010). Os resultados obtidos mostraram que é possível a elaboração de uma ferroliga FeCr-AC a partir de cinzas oriundas do processo de incineração de aparas de couro, por meio da redução carbotérmica nas temperaturas de $1600^{\circ} \mathrm{C}$ e $1300^{\circ} \mathrm{C}$.

Basegio et al. (2006) demonstraram a viabilidade da incorporação da cinza de incineração de aparas de couro na fabricação de refratários de alumina-cromo. Diminuição da porosidade aparente e aumentos na resistência mecânica e retração linear têm sido reportados como efeitos da adição da cinza de incineração de couros. Além disso, os ensaios de lixiviação tem mostrado concentrações de cromo dentro dos limites permitidos.

Os lodos de cromo e os lodos primário e secundário também têm sido objeto de estudo como potencial matéria-prima na fabricação de corpos cerâmicos, principalmente na cerâmica vermelha (BASEGIO et al., 2002; KELLER, 1997; OLIVEIRA, 2008), tijolos (GIUGLIANO; PAGGI, 1985) e porcelanato (FERNANDES; FERREIRA, 2007). Os resultados destes estudos mostraram que esses resíduos, dependendo do teor de cromo na sua composição, podem ser utilizados em pequenas quantidades na fabricação de cerâmica vermelha. Ensaios de lixiviação mostraram que o cromo em baixos teores pode ser estabilizado no material cerâmico e que estes produtos podem ser utilizados com segurança. 
Abreu e Toffoli (2009) estudaram o uso de um lodo de cromo, após lavagem e incineração a $700^{\circ} \mathrm{C}$, como pigmento na formulação de vidrados. Os vidrados preparados a partir da fusão da mistura das cinzas e um vidrado comercial apresentaram boas características visuais (tom de cor, textura e brilho) e boa estabilidade do cromo no vidro.

A imobilização das cinzas da incineração de aparas de couro em compostos quimicamente não-reativos ou estáveis por meio da vitrificação tem sido estudada por Basegio et al. (2009). As cinzas foram misturadas com um vidro sodo-cálcico numa proporção 2:1, homogeneizadas e fundidas a temperaturas entre $750{ }^{\circ} \mathrm{C}$ e $1000^{\circ} \mathrm{C}$. A incorporação das cinzas no vidro produziram uma redução nos níveis de absorção de água e aumentaram a retração linear nos corpos cerâmicos. Os ensaios de lixiviação mostraram que os níveis de lixiviação de cromo, não são afetados apenas pela densidade dos corpos cerâmicos, mas também pela presença de compostos de sódio em sua composição.

Outros autores têm estudado também a imobilização dos resíduos sólidos provenientes da indústria de curtume, aparas de couro (RIBEIRO; YUAN; MORELLI, 2011; TACHARD; RIBEIRO; MORELLI, 2006; YUAN, 2009) e lodos contendo compostos de cromo (PINTO, 2005; PINTO et al., 2006), em matrizes cimentícias com o objetivo de estabilizar os resíduos como tratamento prévio à disposição final em aterros sanitários. A adição de resíduo tratado aumenta ligeiramente a porosidade do cimento e produz mudanças significativas na formação dos compostos químicos do cimento. Foram observados também índices de lixiviação dentro das dosagens estabelecidas, mostrando que o cromo permanece estabilizado efetivamente na matriz cimentícia.

Costa (2009) estudou o coprocessamento de resíduos sólidos de curtumes (aparas de couro) contaminados com cromo, como uma fonte alternativa de poder calorífico nos fornos de fabricação de cimento. Os resultados obtidos demonstraram a viabilidade técnica para o coprocessamento destes resíduos em fornos de cimenteira, desde que respeitados os limites de concentrações na formulação das matérias-primas. 


\section{Materiais e métodos}

Neste capítulo serão descritos os materiais e procedimentos experimentais empregados no decorrer da pesquisa, assim como as técnicas utilizadas para a caracterização das amostras preparadas neste trabalho.

\subsection{Síntese das atividades}

No diagrama de blocos apresentado na Figura 3.1 ilustra-se de forma resumida a metodologia empregada durante o desenvolvimento deste trabalho. A descrição de cada item será abordada conforme a sequência apresentada no diagrama.

Figura 3.1 - Esquema de atividades

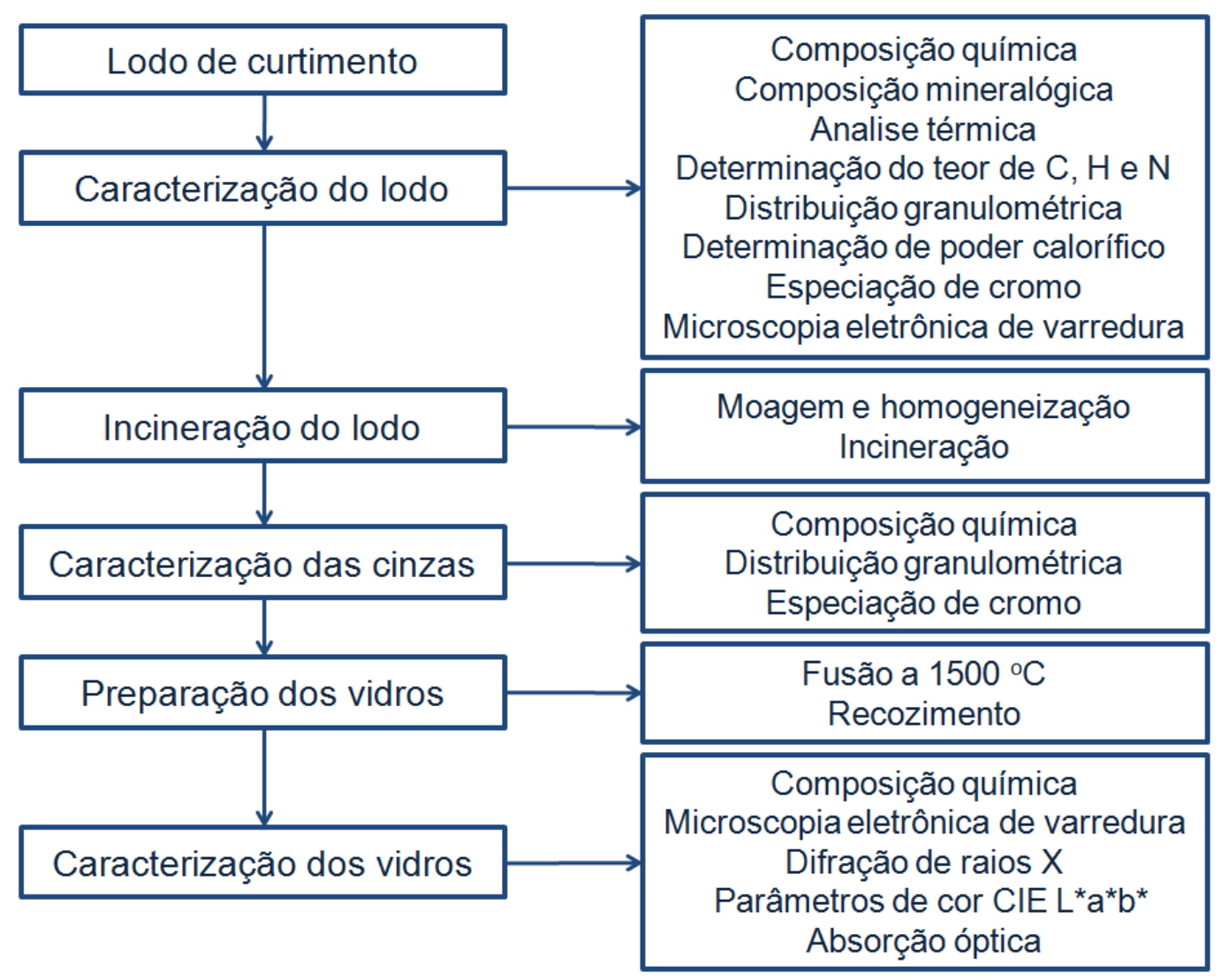

Fonte: elaborado pelo autor. 


\subsection{Materiais}

Para a realização do trabalho foram visitadas três empresas produtoras de couro localizadas no distrito industrial do município de Franca, São Paulo, com o intuito de verificar o processo de produção, a quantidade e as formas de armazenamento e descarte dos resíduos gerados. Foram coletados dois tipos de resíduo, um lodo rico em cromo ("lodo de cromo") resultante do processo de tratamento dos efluentes (precipitação química e secagem mecânica) provenientes da etapa de curtimento, e outro lodo com baixo conteúdo de cromo ("lodo primário-secundário") resultante do tratamento (tratamento físico-químico e biológico) dos efluentes provenientes das outras etapas do processo de produção de couro. Foram recolhidas três amostras diferentes do lodo de cromo (cada uma com aproximadamente $5 \mathrm{~kg}$ ) de duas empresas produtoras de couro e uma amostra de lodo primário-secundário (de aproximadamente $3 \mathrm{~kg}$ ) da unidade centralizada de tratamento de efluentes da AMCOA. Na Figura 3.2 são apresentadas as amostras coletadas de lodo de cromo e o lodo primário-secundário.

Figura 3.2 - Amostras de lodo de cromo (A, B e C) e o lodo primário-secundário (D) coletadas no município de Franca, SP.

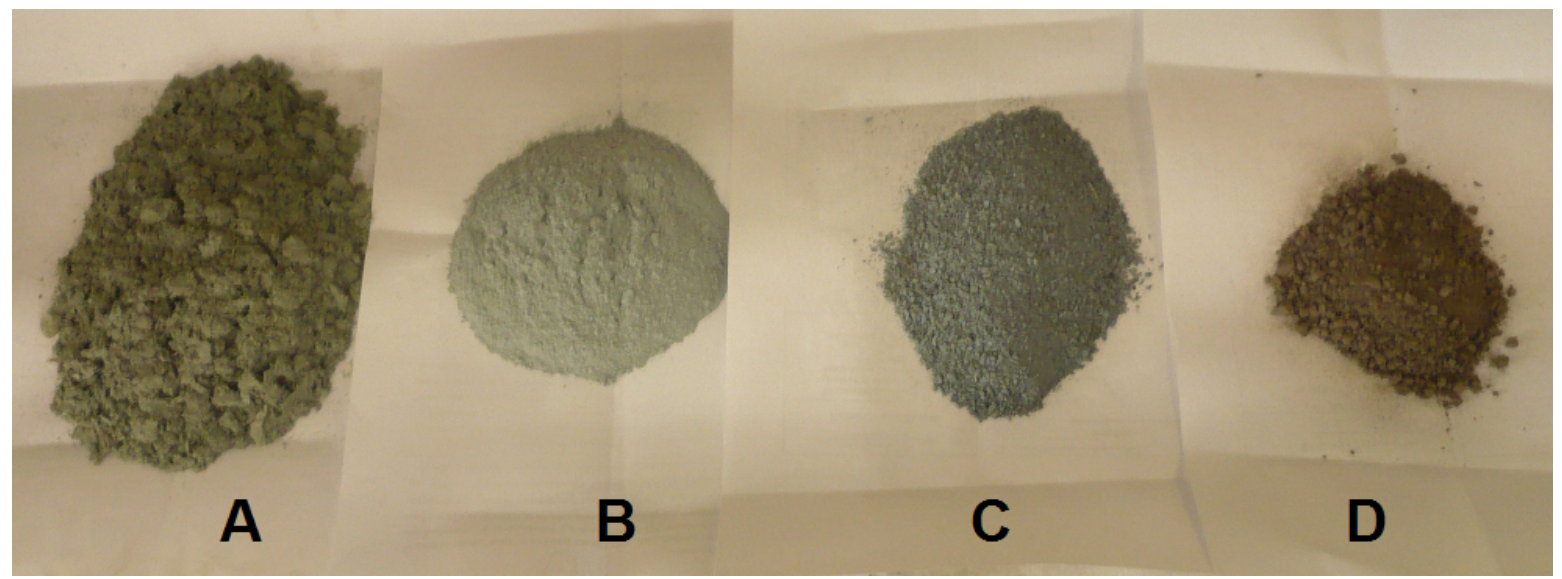

Fonte: elaborado pelo autor.

A coleta de cada amostra foi realizada retirando-se porções de material em vários pontos da massa do precipitado. Os lodos de cromo coletados (amostras A, B e C na Figura 3.2) apresentaram a forma de precipitados de coloração verde, com diferentes teores de umidade, de granulação grossa, com a presença de impurezas como pedaços de tecido, restos de plásticos e materiais orgânicos. Estes resíduos após precipitação são normalmente filtrados em sacos de pano para a remoção do excesso de água e armazenados em tambores de plástico (Figura 3.3) até a disposição final em aterro sanitário. A amostra de lodo primário-secundário (amostra D na Figura 3.2) apresentou uma coloração marrom escura de aparência floculada e de odor levemente desagradável. 
Figura 3.3 - Lodo de cromo após precipitação e secagem mecânica.

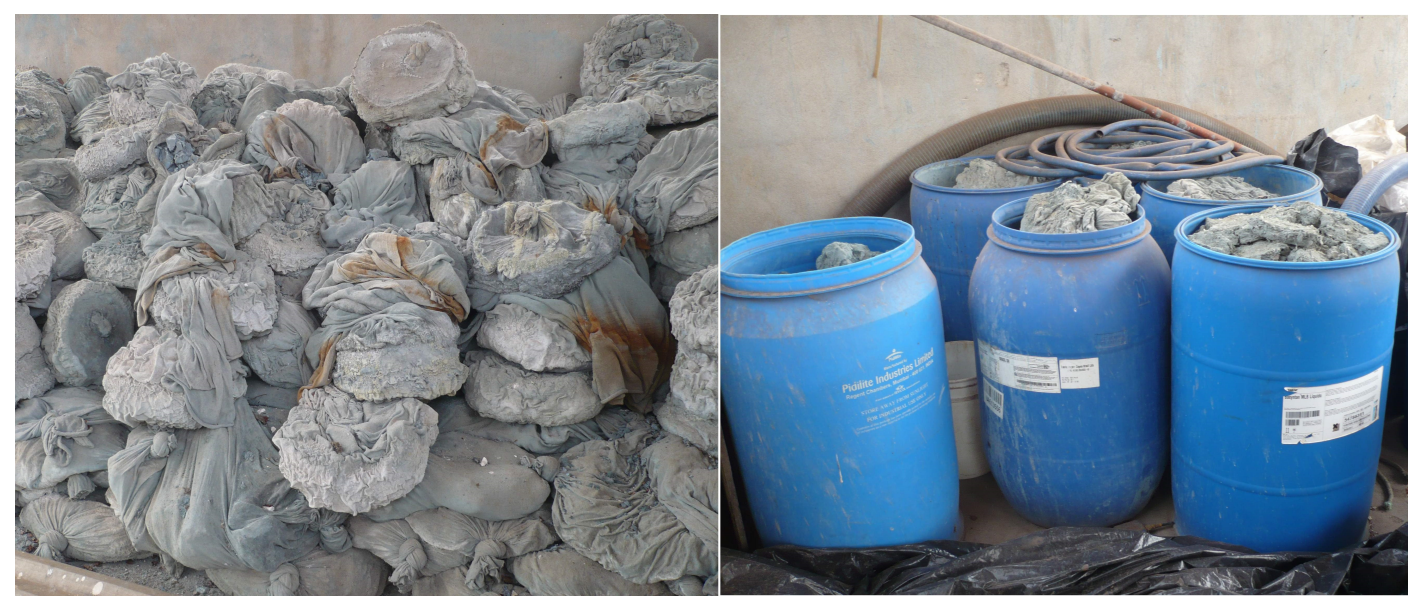

Fonte: elaborado pelo autor.

Entre os resíduos coletados foi escolhida a amostra de lodo de cromo identificada como amostra B (Figura 3.2) para realizar a incineração e utilizar as cinzas resultantes deste processo como fonte de cromo na preparação dos vidros verdes. A escolha foi realizada com base no tipo de processo de produção e o tamanho da empresa de origem do resíduo. A empresa escolhida é uma empresa de médio porte que realiza o processamento completo de couros (processamento desde peles cruas até couro acabado).

Para a preparação das amostras de vidro foram empregadas as matérias-primas comumente usadas na produção industrial de vidros sodo-cálcicos comerciais (areia, barrilha e calcário) assim como os os pigmentos usualmente utilizados na produção de vidros verdes (cromita e hematita). As matérias-primas assim como os pigmentos foram fornecidos por uma reconhecida empresa de fabricação de vidros de grande porte, estabelecida no estado de São Paulo. Coque de petróleo finamente moído (250 mesh) foi utilizado como agente redutor na fabricação de algumas amostras de vidros.

\subsection{Métodos}

\subsubsection{Técnicas de caracterização}

\subsubsection{Composição química por Fluorescência de Raios X (FRX)}

A composição química das amostras coletadas e das matérias-primas foi determinada utilizando a técnica semiquantitativa de FRX (base seca) por Dispersão de Comprimento de Onda (WDS), análise sem padrões (standardless) de elementos químicos de flúor a 
urânio, fazendo uso do equipamento Axios Advanced, PANalytical, disponível no Laboratório de Caracterização Tecnológica (LCT) do Departamento de Engenharia de Minas e de Petróleo (PMI) da Escola Politécnica da Universidade de São Paulo (EPUSP). A Perda ao Fogo (PF) foi determinada a $1050^{\circ} \mathrm{C}$ por $1 \mathrm{~h}$.

\subsubsection{Composição mineralógica por Difração de Raios X (DRX)}

A técnica de difração de raios $X$ em pó foi empregada neste trabalho com o objetivo de identificar as fases cristalinas presentes no lodo de cromo assim como verificar a natureza vítrea dos vidros preparados. Os ensaios de difração de raios $X$ foram realizados em um difratômetro Siemens D-5000, disponível no Laboratório de Difração de Raios X (LDRX) do Instituto de Geociências (IGC) da Universidade de São Paulo (USP), utilizando a radiação do cobre $\mathrm{K} \alpha\left(\lambda=1.5418 \AA\right.$ ), com passos de $0,05^{\circ}$ e tempo de 1 segundo de permanência.

\subsubsection{Análise térmica diferencial e termogravimétrica}

O comportamento térmico do lodo de cromo foi estudado utilizando as técnicas de Análise Térmica Diferencial (DTA) e Termogravimetria/Termogravimetria Derivada (TG/DTG) usando o equipamento Netzsch, modelo STA409C, disponível no Departamento de engenharia de Metalúrgica e de Materiais (PMT) da EPUSP, desde a temperatura ambiente até $1000^{\circ} \mathrm{C}$, com taxa de aquecimento de $5^{\circ} \mathrm{C} / \mathrm{min}$ e sob atmosfera de ar.

\subsubsection{Determinação do teor de carbono, hidrogênio, nitrogênio e umidade}

A determinação dos teores de carbono, hidrogênio e nitrogênio presentes no lodo de cromo estudado foi realizada por análise elementar utilizando o equipamento Elemental Analyzer 2400 CHN Perkin Elmer, disponível na central analítica do Instituto de Química (IQ) da USP. O teor de umidade do lodo estudado foi determinado com base na norma ASTM-D2974. O ensaio consistiu na pesagem de aproximadamente $50 \mathrm{~g}$ da amostra do resíduo num cadinho de porcelana, em seguida o cadinho foi levado para estufa aquecida a $105{ }^{\circ} \mathrm{C}$ e deixado pelo menos por 16 horas. Finalmente as amostras foram retiradas da estufa colocadas em dessecador e posteriormente pesadas. A porcentagem de umidade foi calculada segundo fórmula descrita embaixo. Onde A e B representam, respectivamente, a massa da amostra recebida e da amostra seca na estufa.

Teor de umidade $(\%)=[(\mathrm{A}-\mathrm{B}) \times 100] / \mathrm{A}$ 


\subsubsection{Determinação do tamanho de partícula}

A distribuição do tamanho de partículas do lodo de cromo estudado assim como das matérias-primas utilizadas para a preparação dos vidros foi realizada utilizando a análise de imagens por fluxo dinâmico no equipamento da marca Retsch, modelos Camsizer $L$ (30 $\mu \mathrm{m}$ a $30 \mathrm{~mm}$ ) e Camsizer XT ( $1 \mu \mathrm{m}$ a $3 \mathrm{~mm}$ ), disponível no LCT da USP.

\subsubsection{Determinação do poder calorífico e teor de cinzas}

O teor de cinzas (base úmida) do lodo de cromo estudado foi calculado com base ao material resultante do processo de incineração a $800^{\circ} \mathrm{C}$. Os valores de Poder Calorífico Superior (PCS) e PCl do lodo de cromo foram determinados pelo método da bomba calorimétrica baseada na norma ASTM-D5468. Adicionalmente foram calculados também os valores de PCS utilizando a fórmula modificada de Dulong (NIESSEN, 2002), descrita embaixo. Onde $\mathrm{C}, \mathrm{H}, \mathrm{O}$, e $\mathrm{S}$ representam as frações das porcentagens em peso de carbono, hidrogênio, oxigênio e enxofre.

$$
\text { Calor de combustão }(\mathrm{kcal} / \mathrm{kg})=8080 \mathrm{C}+34460 \mathrm{H}-4308 \mathrm{O}+2250 \mathrm{~S}
$$

\subsubsection{Determinação das espécies de cromo}

A determinação das espécies de íons cromo presentes no lodo de cromo e nas cinzas da incineração foi realizada de acordo com os métodos de análise descritos pela U.S. EPA. A concentração total de íons de cromo foi determinada utilizando a Espectrometria de Emissão Atômica por Plasma Acoplado Indutivamente (ICP-AES), procedimento EPA 6010C, e digestão ácida como etapa prévia (EPA 3050B). A concentração de íons Cr(VI), foi determinada pelo método colorimétrico utilizando difenilcarbazida como reagente cromogênico (EPA 7196A). Os ensaios foram realizados pelo Centro de Qualidade Analítica Ldta. (CQA), Campinas/SP.

\subsubsection{Microscopia Eletrônica de Varredura (MEV) e Espectroscopia de Energia Dispersiva de Raios X (EDS)}

Com o intuito de estudar a morfologia do lodo de cromo estudado assim como observar a homogeneidade e a presença de infundidos e bolhas nos vidros preparados foi utilizado o microscópio eletrônico de varredura Philips XL30 acoplado à microssonda EDAX para análise espectroscópica de energia dispersiva de raios $X$ (EDS). 


\subsubsection{Determinação das coordenadas colorimétricas}

As coordenadas colorimétricas no sistema CIE $L^{*} a^{*} b^{*}$ dos vidros comerciais e dos vidros preparados experimentalmente foram obtidos por refletância e transmitância, ambos utilizando o iluminante D65 (luz do dia) e observador padrão de $10^{\circ}$. As medições por refletância foram realizadas utilizando um espectrofotômetro Minolta modelo CM-3700A, disponível no Departamento de Dentística da Faculdade de Odontologia da USP. As medições por transmitância foram realizadas utilizando um espectrofotômetro, na região de 400 a 750 nm, na Faculdade de Tecnologia de São Paulo (FATEC-SP).

\subsubsection{Absorção óptica}

Os espectros de absorção óptica na faixa de 200 a $3300 \mathrm{~nm}$ foram obtidos usando o espectrofotómetro UV-vis-NIR Varian Cary 500, disponível no Laboratório de cristais lônicos, Filmes Finos e Datação (LACIFID) do Instituto de Física da USP (IFUSP). Os vidros preparados experimentalmente foram previamente lixados e polidos usando lixas de água e pasta de diamante de 6,3 e $1 \mu$ m lubrificados com álcool etílico. Para fins de comparação, também foram realizadas medidas de absorção óptica de vidros comerciais utilizados para armazenar refrigerantes, cervejas e vinhos. Devido à diferença de espessuras entre as amostras dos vidros comerciais e dos vidros preparados experimentalmente foram calculados os coeficientes de absorção óptica de todas as amostras, tanto dos vidros comerciais como dos vidros preparados experimentalmente, conforme a equação mostrada a continuação (HOLT, 2009).

$$
A=\ln \left(\frac{I_{a}}{I_{0}}\right)=\alpha \cdot d
$$

Onde:

$A=$ Absorbância

$\mathrm{I}_{a}=$ Intensidade da luz absorvida

$\mathrm{I}_{0}=$ Intensidade da luz incidente

$\alpha=$ Coeficiente de absorção óptica $\left(\mathrm{cm}^{-1}\right)$

$d=$ Distância que a luz atravessa no corpo $(\mathrm{cm})$ 


\subsubsection{Incineração do lodo de cromo}

\subsubsection{Moagem e homogeneização}

As amostras de lodos coletadas no município de Franca foram trituradas e homogeneizadas fazendo uso de um moinho de rolos. O material resultante foi quarteado, a fim de obter-se uma amostra reduzida, mas representativa para a realização dos ensaios de caracterização. Na Figura 3.4 apresenta-se a amostra representativa do lodo de cromo escolhido para ser incinerado e utilizado como agente colorante nos vidros.

Figura 3.4 - Lodo de cromo após moagem, homogeneização e quarteamento.

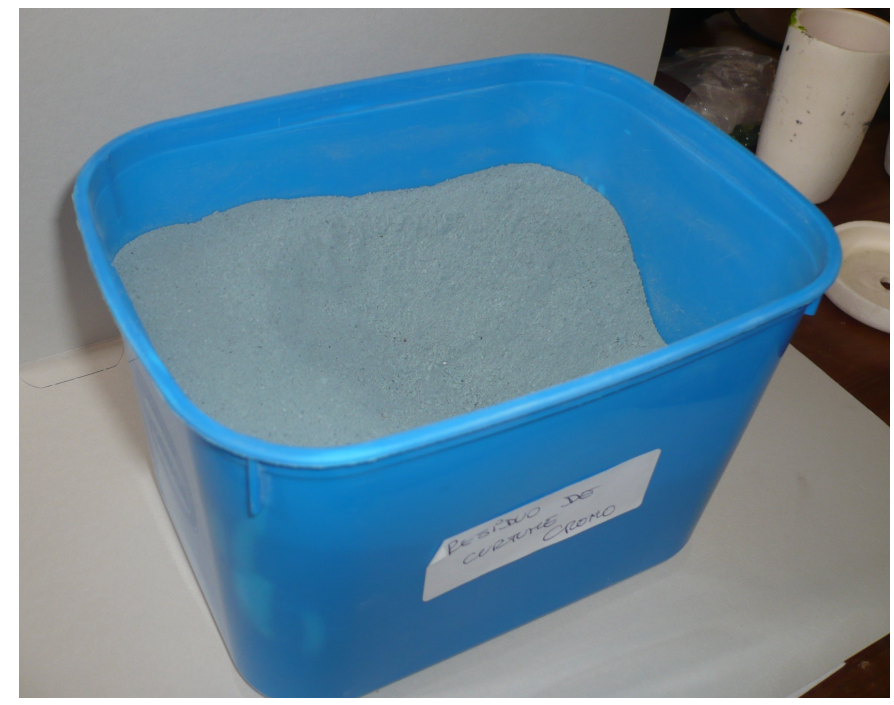

Fonte: elaborado pelo autor.

\subsubsection{Processo de incineração}

O processo de incineração utilizado no presente trabalho teve por objetivo a eliminação do conteúdo de matéria orgânica presente no resíduo estudado, visando obter um material mais homogêneo. A escolha da temperatura de incineração foi realizada com base em dois critérios: garantir a eliminação da matéria orgânica e obter um material com baixo teor de $\mathrm{Cr}(\mathrm{VI})$. Segundo a bibliografia a incineração de resíduos sólidos perigosos é realizada normalmente a temperaturas acima de $800{ }^{\circ} \mathrm{C}$ (FONSECA; MARCHI, 2009; NIESSEN, 2002; LAZAU et al., 2007), no entanto é sabido também que o aumento de temperatura, durante a incineração em condições oxidantes, favorece a formação de $\mathrm{Cr}(\mathrm{VI})$ (MARTINS, 2001). A fim de minimizar os riscos de exposição ao $\mathrm{Cr}(\mathrm{VI})$ durante os procedimentos experimentais a temperatura de incineração escolhida foi de $800{ }^{\circ} \mathrm{C}$, temperatura suficiente para decompor a maior parte de matéria orgânica presente no resíduo. 
O processo de incineração consistiu na pesagem de 60 gramas do lodo de cromo, previamente misturado e homogeneizado, num cadinho de alumina de aproximadamente $100 \mathrm{~mL}$. Após a pesagem o cadinho foi levado a mufla elétrica, onde foi incinerado a $800{ }^{\circ} \mathrm{C}$, com taxa de aquecimento de $10^{\circ} \mathrm{C} / \mathrm{min}$ e um patamar de 1 hora. Após a incineração o material foi deixado resfriar dentro do forno até temperatura ambiente para ser posteriormente retirado e identificado. Na Figura 3.5 mostra-se o cadinho utilizado na incineração do resíduo e a amostra de lodo de cromo antes e após incineração.

Figura 3.5 - Lodo de cromo (A), cadinho de alumina e lodo incinerado a $800^{\circ} \mathrm{C}(\mathrm{B})$.

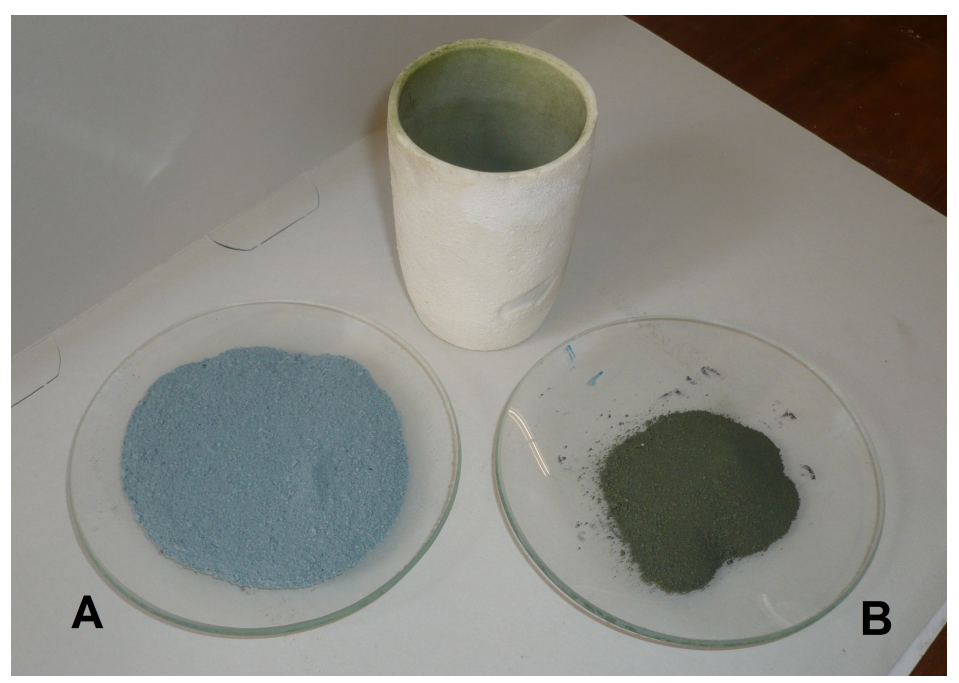

Fonte: elaborado pelo autor.

\subsubsection{Preparação dos vidros}

Utilizando como base uma composição modelo de vidro sodo-cálcico (em massa: $75 \%$ $\mathrm{SiO}_{2}, 15 \% \mathrm{Na}_{2} \mathrm{O}$ e $10 \% \mathrm{CaO}$ ) e com base nos conteúdos medios de colorantes dos vidros verdes para embalagem, de $0,02-0,3 \%$ de $\mathrm{Cr}_{2} \mathrm{O}_{3}$ e $0,02-0,4 \%$ de $\mathrm{Fe}_{2} \mathrm{O}_{3}$ (VOLF, 1984; MILLS; JASINSKI, 1982), foram preparadas amostras de vidros sodo-cálcicos contendo $0,1 \%$ de $\mathrm{Cr}_{2} \mathrm{O}_{3}$ e $0,2 \%$ de $\mathrm{Fe}_{2} \mathrm{O}_{3}$ utilizando duas fontes diferentes de cromo: cinzas provenientes da incineração do lodo de cromo e cromita (fonte industrial típica de cromo usada na fabricação de vidros verdes). Para alcançar os mesmos valores de $\mathrm{Fe}_{2} \mathrm{O}_{3}$ em ambos os vidros foi utilizada hematita como fonte de ferro. Adicionalmente, com o propósito de estudar a influência do ferro nos vidros contendo cromo foram preparados também vidros sem a adição de hematita. As composições nominais dos vidros preparados neste trabalho foram calculadas estequiometricamente com base nos resultados da análise de FRX das matérias-primas. Na Tabela 3.1 apresentam-se as composições nominais dos vidros preparados. 
Tabela 3.1 - Composições nominais das amostras de vidros.

\begin{tabular}{lccccc}
\hline Amostra & \multicolumn{5}{c}{ Composição nominal (\% em massa) } \\
\hline & $\mathrm{SiO}_{2}$ & $\mathrm{Na}_{2} \mathrm{O}$ & $\mathrm{CaO}$ & $\mathrm{Cr}_{2} \mathrm{O}_{3}$ & $\mathrm{Fe}_{2} \mathrm{O}_{3}$ \\
Cromita & 74,86 & 15,00 & 10,00 & 0,10 & 0,04 \\
Cromita+hematita & 74,90 & 15,00 & 10,00 & 0,10 & 0,20 \\
Cinzas & 74,70 & 15,00 & 10,00 & 0,10 & 0,00 \\
Cinzas+hematita & 74,70 & 15,00 & 10,00 & 0,10 & 0,20 \\
\hline
\end{tabular}

Os vidros produzidos neste trabalho foram obtidos por meio da fusão das matériasprimas (areia, barrilha e calcário) junto com quantidades adequadas das fontes de cromo e ferro, em forno elétrico, utilizando-se cadinhos de alumina de alta pureza preparados em laboratório. As matérias-primas assim como as fontes de cromo e ferro foram secas em mufla, e em seguida pesadas em balança analítica nas quantidades adequadas para obter-se $50 \mathrm{~g}$ de vidro fundido com as composições-objetivo descritas na Tabela 3.1.

A areia, barrilha, calcário, hematita e cromita foram utilizadas com as granulometrias fornecidas, ou seja, aquelas empregadas pela indústria vidreira. Já as cinzas do lodo de cromo foram moídas em almofariz a fim de facilitar sua dispersão na matriz vítrea. Foram preparados também vidros com as mesmas composições, mas sob condições redutoras. Para este propósito foi utilizada uma pequena quantidade de coque de petróleo $(0,2 \%$ da massa total da mistura de matérias-primas) como agente redutor. Estes vidros foram identificados com uma letra "R" ao final do código das amostras. As quantidades de cada matéria-prima utilizada na formulação dos vidros são mostradas na Tabela 3.2

Tabela 3.2 - Matérias-primas utilizadas na formulação dos vidros.

\begin{tabular}{lccccccc}
\hline \multirow{2}{*}{ Amostra } & \multicolumn{7}{c}{ Matérias-primas $(\mathrm{g})$} \\
& Areia & Barrilha & Calcário & Cinzas & Cromita & Hematita & Coque \\
\hline Cromita & 37,429 & 12,822 & 8,921 & & 0,117 & & \\
Cromita+hematita & 37,349 & 12,822 & 8,921 & & 0,117 & 0,080 & \\
Cinzas & 37,449 & 12,822 & 8,921 & 0,106 & & & \\
Cinzas+hematita & 37,349 & 12,822 & 8,921 & 0,106 & & 0,100 & \\
Cromita R & 37,429 & 12,822 & 8,921 & & 0,117 & & 0,119 \\
Cromita+hematita R & 37,349 & 12,822 & 8,921 & & 0,117 & 0,080 & 0,119 \\
Cinzas R & 37,449 & 12,822 & 8,921 & 0,106 & & & 0,119 \\
Cinzas+hematita R & 37,349 & 12,822 & 8,921 & 0,106 & & 0,100 & 0,119 \\
\hline
\end{tabular}


A mistura das matérias-primas e as fontes de cromo e ferro foram fundidas no cadinho de alumina a uma temperatura de $1500{ }^{\circ} \mathrm{C}$, com taxa de aquecimento de $5^{\circ} \mathrm{C} / \mathrm{min}$ e um patamar de 1 hora. Após a fusão, o forno foi desligado e as amostras foram deixadas para resfriar no interior do forno até à temperatura ambiente. Após o resfriamento as amostras foram recozidas em mufla elétrica por 1 hora a $570{ }^{\circ} \mathrm{C}$ para eliminar as tensões térmicas residuais com posterior resfriamento lento dentro do forno. Após o recozimento, os cadinhos foram retirados do forno, quebrados e cortados em máquina de corte de disco diamantado. Os vidros foram extraídos e cortados em dimensões adequadas para realizar os diferentes ensaios. Na Figura 3.6 mostra-se uma amostra de vidro preparada dentro do cadinho de alumina e uma amostra retirada do cadinho e posteriormente cortada.

Figura 3.6 - Fotografia de uma amostra de vidro dentro do cadinho de alumina $(A)$ e amostra retirada do cadinho e cortada (B e C).

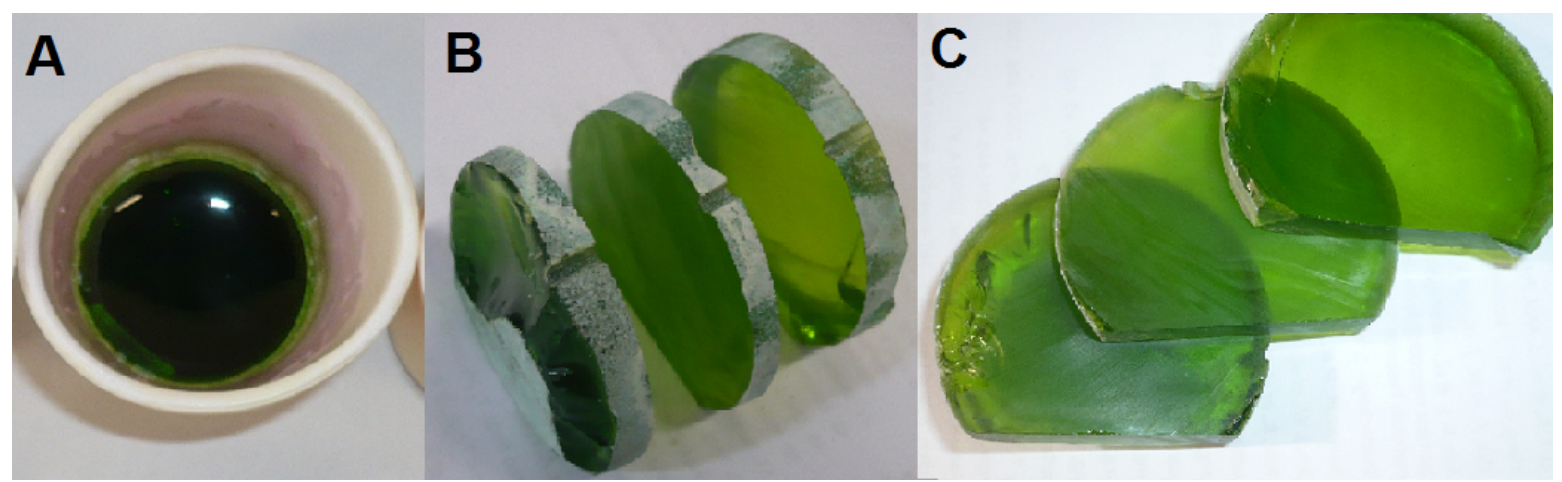

Fonte: elaborado pelo autor. 


\section{Resultados e discussão}

Neste capítulo serão apresentados e discutidos os principais resultados obtidos durante a realização deste trabalho. Na primeira parte serão apresentados os resultados da caracterização do lodo de curtimento estudado e das matérias-primas utilizadas na fabricação dos vidros. Na sequência, serão apresentados os resultados referentes à caracterização das cinzas provenientes do processo de incineração do lodo de curtimento e finalmente serão realizadas comparações em termos de composição química, MEV, DRX, coordenadas colorimétricas no sistema CIE L*a*b* e absorção óptica entre os vidros preparados utilizando as cinzas provenientes da incineração do lodo de cromo e os vidros preparados utilizando cromita.

\subsection{Caracterização do lodo de curtimento}

\subsubsection{Composição química por FRX}

As composições químicas das amostras de lodo de cromo e lodo primário-secundário coletadas são apresentadas na Tabela 4.1. A análise química revelou que os lodos de cromo (lodo A, B e C) possuem altos teores de cromo (expressos em $\mathrm{Cr}_{2} \mathrm{O}_{3}$ ) na sua composição. Estes lodos apresentam aproximadamente 14\%, 38\% e 22\% em massa de $\mathrm{Cr}_{2} \mathrm{O}_{3}$ para os lodos $\mathrm{A}$, B e C, respectivamente. Os valores de $\mathrm{Cr}_{2} \mathrm{O}_{3}$ observados nas amostras de lodo de cromo $\mathrm{A}$ e $\mathrm{C}$ são coerentes com os valores de $\mathrm{Cr}_{2} \mathrm{O}_{3}$ reportados por Abreu (2006) para lodos de cromo provenientes do município de Franca/SP, que apresentam $20,6 \%$ e $21,6 \%$ em massa de $\mathrm{Cr}_{2} \mathrm{O}_{3}$. Os valores de $\mathrm{Cr}_{2} \mathrm{O}_{3}$ observados nas amostras A e $\mathrm{C}$ também são semelhantes aos valores reportados por outros autores para lodos de cromo provenientes de outras regiões do Brasil. Como por exemplo, Campo Grande (MS) e Natal (RN), que apresentam 25,5\% (OLIVEIRA, 2008) e 13,3\% em massa de $\mathrm{Cr}_{2} \mathrm{O}_{3}$ (DANTAS et al., 2009), respectivamente. A amostra de lodo de cromo B apresentou um teor de cromo relativamente alto (aproximadamente $38 \%$ em massa de $\mathrm{Cr}_{2} \mathrm{O}_{3}$ ) em comparação com os valores observados nos lodos de cromo A e C. Esta diferença pode ser relacionada aos diferentes insumos e processos utilizados na fabricação do couro e no tratamento dos efluentes das empresas onde foram coletados os resíduos. 
Tabela 4.1 - Composição química dos lodos de cromo e lodo primário-secundário.

\begin{tabular}{ccccc}
\hline & \multicolumn{4}{c}{ Porcentagem em massa (\%) } \\
Óxidos & \multicolumn{2}{c}{ Lodos de curtimento } & $\begin{array}{c}\text { Lodo primário-secundário } \\
\text { Lodo } \mathrm{D}\end{array}$ \\
\hline $\mathrm{SiO}_{2}$ & 1,60 & 2,07 & 4,32 & 1,62 \\
$\mathrm{Al}_{2} \mathrm{O}_{3}$ & 0,09 & 0,40 & 0,82 & 5,95 \\
$\mathrm{Na}_{2} \mathrm{O}$ & 3,26 & 2,78 & 0,95 & 1,10 \\
$\mathrm{~K}_{2} \mathrm{O}$ & 0,03 & 0,04 & 0,11 & 0,09 \\
$\mathrm{CaO}$ & 19,59 & 6,87 & 2,34 & 10,50 \\
$\mathrm{MgO}$ & 4,22 & 2,46 & 0,41 & 0,44 \\
$\mathrm{Cr}_{2} \mathrm{O}_{3}$ & 14,10 & 37,56 & 22,01 & 1,98 \\
$\mathrm{Fe}_{2} \mathrm{O}_{3}$ & 0,20 & 1,03 & 1,34 & 2,87 \\
$\mathrm{TiO}_{2}$ & & 0,03 & 0,09 & 0,34 \\
$\mathrm{ZrO}$ & & \\
$\mathrm{V}_{2} \mathrm{O}_{5}$ & 0,03 & & 0,02 & 0,01 \\
$\mathrm{NiO}$ & 0,03 & 0,07 & 0,03 & 0,01 \\
$\mathrm{CuO}$ & & 0,01 & 0,03 & 0,01 \\
$\mathrm{ZnO}$ & 0,01 & 0,03 & 0,03 & 0,06 \\
$\mathrm{SrO}$ & 0,08 & 0,05 & 0,03 & 0,04 \\
$\mathrm{PbO}$ & & 0,01 & & 0,04 \\
$\mathrm{MnO}$ & & & & 0,02 \\
$\mathrm{BaO}$ & & & 0,06 & 6,08 \\
$\mathrm{SO}{ }_{3}$ & 27,09 & 6,63 & 3,51 & 0,46 \\
$\mathrm{P}_{2} \mathrm{O}_{5}$ & 0,15 & 2,27 & 1,57 & 1,07 \\
$\mathrm{Cl}$ & 2,73 & 4,03 & 0,68 & 67,31 \\
$\mathrm{PF}$ & 26,79 & 33,67 & 61,62 & 100,00 \\
\hline $\mathrm{Total}$ & 100,00 & 100,00 & 100,00 & \\
\hline
\end{tabular}

O lodo primário-secundário (lodo D) apresentou um baixo teor de $\mathrm{Cr}_{2} \mathrm{O}_{3}$, aproximadamente $2 \%$ em massa (equivalente a $1,35 \%$ em massa de $\mathrm{Cr}$ ) o qual é próximo aos teores, em porcentagem em massa de $\mathrm{Cr}$, observados em outros trabalhos, 0,8\% (BASEGIO et al., 2002), 2,17\% (OLIVEIRA et al., 2008) e 0,45\% (GUIMARÃES, 2008), para lodos primários e secundários provenientes das ETEs da indústria de curtume.

$\mathrm{Na}$ Tabela 4.2 são apresentadas as composições químicas dos lodos de cromo provenientes de empresas curtidoras localizadas em Franca/SP (ABREU, 2006), Campo Grande/MS (OLIVEIRA, 2008) e Natal/RN (DANTAS et al., 2009). Comparando estes resultados com os resultados da análise química dos lodos estudados (Tabela 4.1) podemos observar que existem variações significativas nos teores de alguns elementos, tais como $\mathrm{Na}_{2} \mathrm{O}, \mathrm{MgO}, \mathrm{Fe}_{2} \mathrm{O}_{3}, \mathrm{Cl}$ e $\mathrm{SO}_{3}$, as quais estariam relacionadas com os diferentes tipos e quantidades de reagentes químicos auxiliares usados nos diferentes processos de curtimento. 
Tabela 4.2 - Composição química de lodos de cromo provenientes do tratamento de efluentes da indústria de curtume estudados por outros autores.

\begin{tabular}{|c|c|c|c|c|}
\hline \multirow[t]{2}{*}{ Óxidos } & \multicolumn{4}{|c|}{ Porcentagem em massa $(\%)$} \\
\hline & Franca/SPa & Franca/SPa & Campo Grande/MS ${ }^{b}$ & Natal/RN ${ }^{c}$ \\
\hline $\mathrm{SiO}_{2}$ & 0,93 & 0,97 & 1,35 & 1,72 \\
\hline $\mathrm{Al}_{2} \mathrm{O}_{3}$ & 0,16 & 0,15 & & 4,58 \\
\hline $\mathrm{Na}_{2} \mathrm{O}$ & 5,57 & 7,35 & & 3,61 \\
\hline $\mathrm{K}_{2} \mathrm{O}$ & & & & 0,15 \\
\hline $\mathrm{CaO}$ & 7,15 & 2,51 & 54,48 & 20,05 \\
\hline $\mathrm{MgO}$ & 1,87 & 2,50 & & 1,41 \\
\hline $\mathrm{Cr}_{2} \mathrm{O}_{3}$ & 21,80 & 20,60 & 25,51 & 13,32 \\
\hline $\mathrm{Fe}_{2} \mathrm{O}_{3}$ & 0,16 & 0,22 & 2,46 & 0,77 \\
\hline $\mathrm{ZnO}$ & & & & 0,03 \\
\hline $\mathrm{SrO}$ & & & 0,20 & 0,06 \\
\hline $\mathrm{SO}_{3}$ & 11,50 & 5,60 & 16,01 & 1,01 \\
\hline $\mathrm{P}_{2} \mathrm{O}_{5}$ & 0,36 & 0,36 & & 0,54 \\
\hline $\mathrm{Cl}$ & 5,95 & 7,86 & & 1,79 \\
\hline $\mathrm{Mn}$ & & & & 0,85 \\
\hline PF & 34,70 & 37,70 & & 49,86 \\
\hline Total & 90,15 & 85,82 & 100,00 & 99,75 \\
\hline $\begin{array}{l}\text { Contes: } \\
\text { a Abreu } \\
\text { b Oliveir }\end{array}$ & 2008), res & do determi & $\begin{array}{l}\text { o por FRX. } \\
\text { do por FRX. }\end{array}$ & \\
\hline
\end{tabular}

Comparando os resultados da Tabela 4.1 e da Tabela 4.2 pode-se observar também uma variação significativa no teor de $\mathrm{CaO}$ em todas as amostras de lodo de cromo. Esta variação pode ser atribuída à utilização de diferentes quantidades de hidróxido de cálcio (agente floculante comumente utilizado no processo de precipitação no tratamento dos efluentes da indústria de curtume), bem como ao uso de outro tipo de agentes floculantes (hidróxido de sódio e carbonato de sódio entre outros).

Os lodos estudados neste trabalho mostraram diferentes valores de perda ao fogo, os quais podem estar relacionados à presença de diferentes teores de matéria orgânica, assim como aos diferentes insumos utilizados nos processos de fabricação do couro e tratamento de efluentes. É importante mencionar que grande parte da variabilidade observada nos lodos de cromo estudados pode ser causada também pela presença de corpos estranhos, tais como restos de papel, plásticos e tecidos, os quais são inseridos nos lodos de cromo durante o período que estes permanecem armazenados até a sua disposição final em aterro sanitário. Na Tabela 4.3 são apresentadas as composições químicas das matérias-primas utilizadas na preparação dos vidros sodo-cálcicos. 
Tabela 4.3 - Composição química das matérias-primas utilizadas para a preparação dos vidros sodo-cálcicos.

\begin{tabular}{cccccc}
\hline Óxidos & \multicolumn{5}{c}{ Porcentagem em massa (\%) } \\
& Areia & Barrilha & Calcário & Cromita & Hematita \\
\hline $\mathrm{SiO}_{2}$ & 99,48 & 0,05 & 0,32 & 9,86 & 2,31 \\
$\mathrm{Al}_{2} \mathrm{O}_{3}$ & 0,13 & 0,02 & 0,01 & 12,32 & 1,50 \\
$\mathrm{Na}_{2} \mathrm{O}$ & 0,05 & 58,82 & & 0,12 & \\
$\mathrm{~K}_{2} \mathrm{O}$ & 0,01 & & 0,05 & 0,04 & \\
$\mathrm{CaO}$ & 0,03 & 0,03 & 55,25 & 0,76 & 0,04 \\
$\mathrm{MgO}$ & & & 0,30 & 15,73 & 0,10 \\
$\mathrm{Cr}_{2} \mathrm{O}_{3}$ & & & & 42,68 & 0,04 \\
$\mathrm{Fe}_{2} \mathrm{O}_{3}$ & 0,06 & 0,02 & 0,02 & 17,93 & 95,25 \\
$\mathrm{TiO}_{2}$ & 0,04 & & & 0,31 & 0,05 \\
$\mathrm{ZrO}_{2}$ & 0,02 & & & 0,01 & \\
$\mathrm{~V}_{2} \mathrm{O}_{5}$ & 0,00 & & & 0,12 & 0,02 \\
$\mathrm{Co}_{3} \mathrm{O}_{4}$ & 0,06 & 0,02 & & & \\
$\mathrm{NiO}$ & & & & 0,01 & \\
$\mathrm{ZnO}_{\mathrm{SrO}}$ & & & & 0,05 & \\
$\mathrm{MnO}$ & & & 0,13 & & \\
$\mathrm{SO}_{3}$ & 0,02 & 0,01 & & 0,03 & 0,061 \\
$\mathrm{P}_{2} \mathrm{O}_{5}$ & & & & 0,01 & 0,05 \\
$\mathrm{Cl}$ & & 0,02 & & 0,02 & 0,01 \\
$\mathrm{Perda}$ ao fogo & 0,10 & 41,01 & 43,92 & 0,00 & 0,56 \\
\hline $\mathrm{Total}^{100,00}$ & 100,00 & 100,00 & 100,00 & 100,00 \\
\hline
\end{tabular}

\subsubsection{Composição mineralógica por DRX}

A fim de verificar o efeito da temperatura sobre as fases cristalinas presentes no lodo de cromo escolhido para ser incorporado no vidro (lodo B), amostras deste resíduo foram incineradas a temperaturas entre $400^{\circ} \mathrm{C}$ e $1000^{\circ} \mathrm{C}$, com patamar de $1 \mathrm{~h}$ e uma taxa de aquecimento de $10^{\circ} \mathrm{C} / \mathrm{min}$. Os padrões de difração de raios $\mathrm{X}$ das amostras incineradas são apresentados na Figura 4.1. O padrão de DRX do lodo de cromo como recebido revelou a presença de sulfato de cálcio hidratado $\left(\mathrm{CaSO}_{4} \cdot 2 \mathrm{H}_{2} \mathrm{O}\right.$, ficha JCPDS $\mathrm{n}^{\circ}$ 0330311), provavelmente formado pela reação entre o sulfato básico de cromo e o hidróxido de cálcio utilizado no processo de precipitação, durante o processo de tratamento de efluentes. Embora a análise química tenha revelado um teor considerável de cromo no lodo, aproximadamente $37 \%$ (expressos em $\mathrm{Cr}_{2} \mathrm{O}_{3}$ ), não foram observados picos correspondentes a compostos de cromo na amostra sem calcinar, provavelmente devido a estes compostos estarem formando compostos amorfos (provavelmente hidróxidos) ou à interferência da matéria orgânica presente na amostra. 
Figura 4.1 - Padrões de difração de raios $X$ do lodo de cromo: como recebido e incinerado a várias temperaturas por $1 \mathrm{~h}$. (G) $\mathrm{CaSO}_{4} \cdot 2 \mathrm{H}_{2} \mathrm{O},(\mathrm{C}) \mathrm{Cr}_{2} \mathrm{O}_{3}$ e $(\mathrm{H}) \mathrm{NaCl}$.

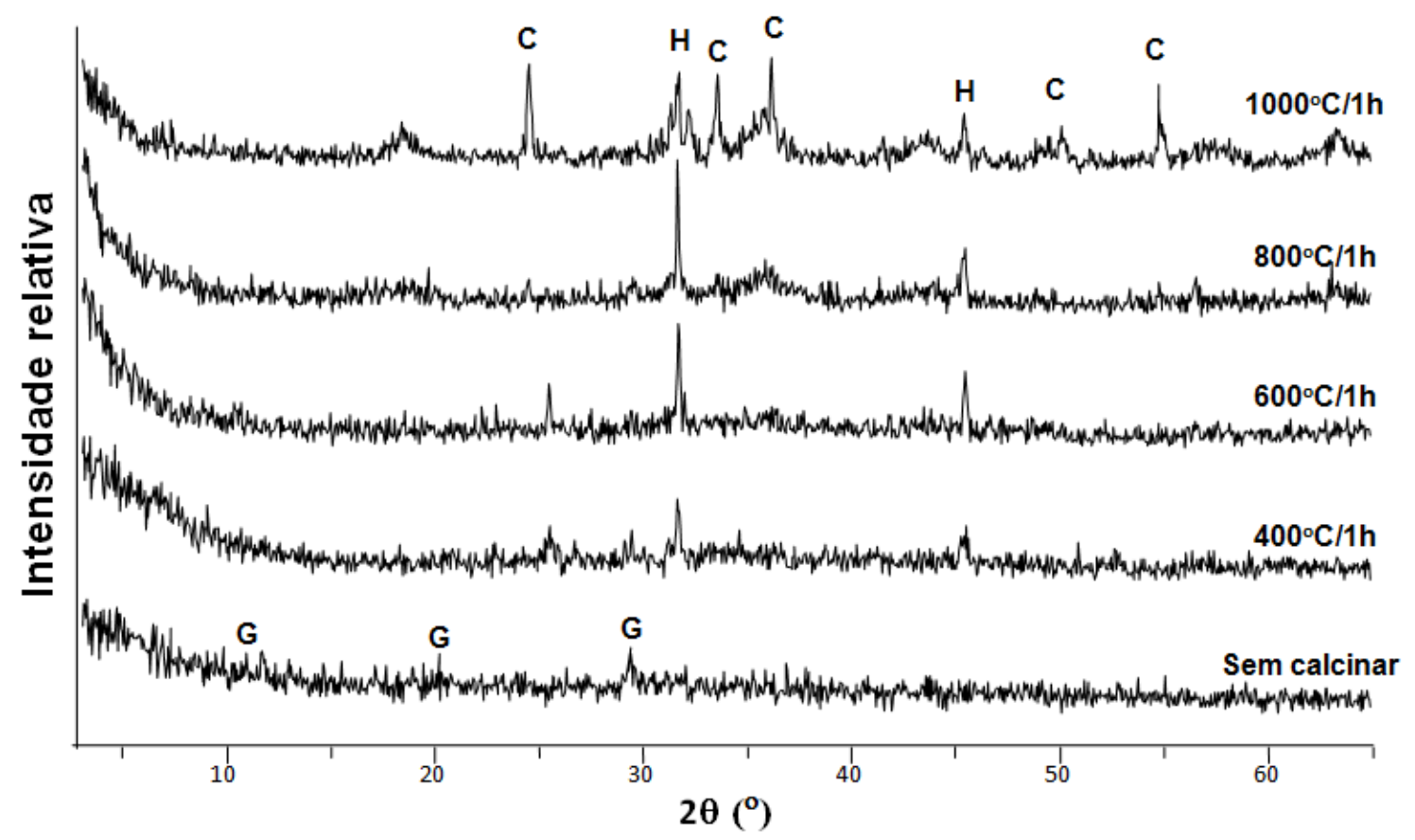

As amostras incineradas a 400,600 e $800^{\circ} \mathrm{C}$ mostraram a presença de $\mathrm{NaCl}$ (JCPDS 05-0628) e o desaparecimento do pico correspondente ao $\mathrm{CaSO}_{4} \cdot 2 \mathrm{H}_{2} \mathrm{O}$ provavelmente causado pela perda de hidroxilas e pela decomposição do sulfato devido ao aumento da temperatura. Na amostra incinerada a $800{ }^{\circ} \mathrm{C}$ podem ser observados os picos de $\mathrm{Cr}_{2} \mathrm{O}_{3}$ (JCPDS 01-070-3765). Após a incineração a $1000{ }^{\circ} \mathrm{C}$, a intensidade dos picos de $\mathrm{Cr}_{2} \mathrm{O}_{3}$ aumentou significativamente. Observou-se também o aparecimento de pequenos picos entre 30 e $35^{\circ}$, os quais poderiam estar relacionados com a formação de outros compostos, provavelmente $\mathrm{Na}_{2} \mathrm{CrO}_{4}, \mathrm{Na}_{2} \mathrm{SO}_{4}$ e $\mathrm{Na}_{4}\left(\mathrm{CrO}_{4}\right)\left(\mathrm{SO}_{4}\right)$.

\subsubsection{Análise térmica diferencial e termogravimétrica}

A análise da curva de DTA do resíduo (Figura 4.2) mostra a presença de um pico endotérmico em temperaturas da ordem de $127{ }^{\circ} \mathrm{C}$, que pode ser associado à perda de água de umidade presente no resíduo estudado. Para temperaturas superiores a 200 ${ }^{\circ} \mathrm{C}$, um crescimento constante na curva de DTA pode ser observado. Este crescimento pode estar relacionado à soma dos fenômenos de decomposição do colágeno e outras proteínas provenientes da matéria orgânica presente no lodo, assim como aos processos de desidratação do $\mathrm{CaSO}_{4} \cdot 2 \mathrm{H}_{2} \mathrm{O}$, que ocorre a temperaturas ao redor de $600{ }^{\circ} \mathrm{C}$, e a decomposição térmica do $\mathrm{CaSO}_{4}$. 
Figura 4.2 - Curva de análise térmica diferencial do lodo de cromo.

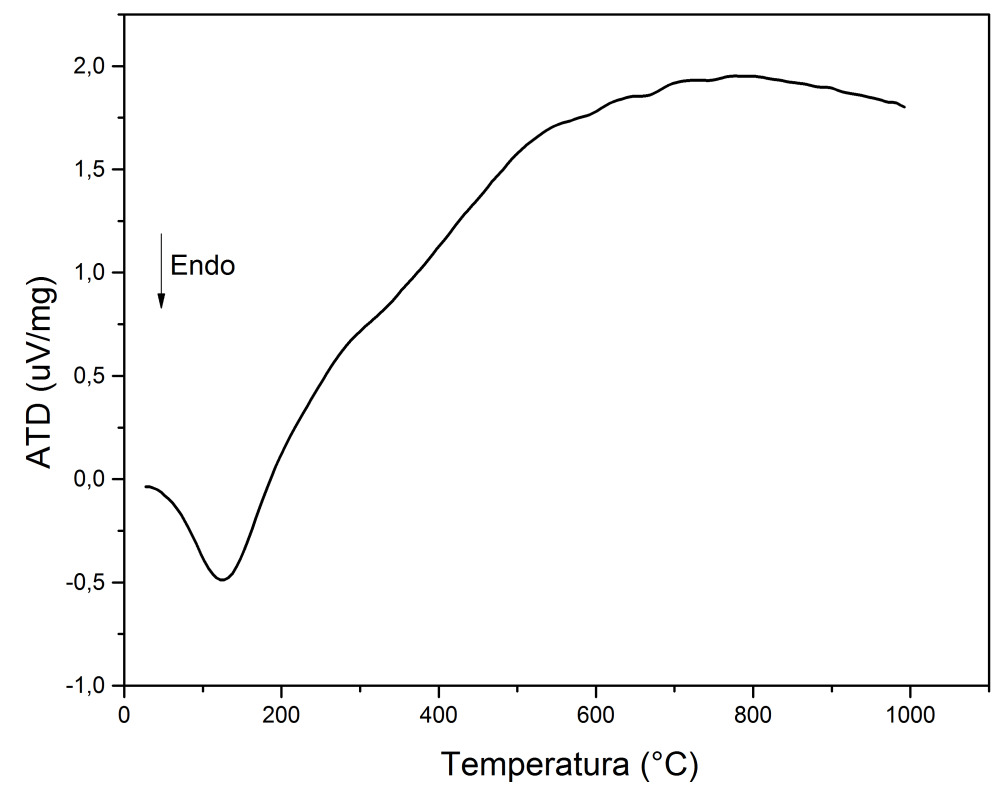

$\mathrm{Na}$ Figura 4.3 observa-se uma perda de massa inicial (aproximadamente 25\%) no intervalo de 27 a $220{ }^{\circ} \mathrm{C}$, que estaria relacionada à perda de água de umidade da amostra. Entre 220 e $420^{\circ} \mathrm{C}$ observa-se a presença de duas perdas discretas de massa, relacionadas à degradação do colágeno e outras proteínas da matéria orgânica presente nos resíduos (LAURENTI, 2007), processos que se somam e geram a curva resultante observada no gráfico.

Figura 4.3 - Curvas de análise termogravimétrica e diferencial termogravimétrica do lodo de cromo.

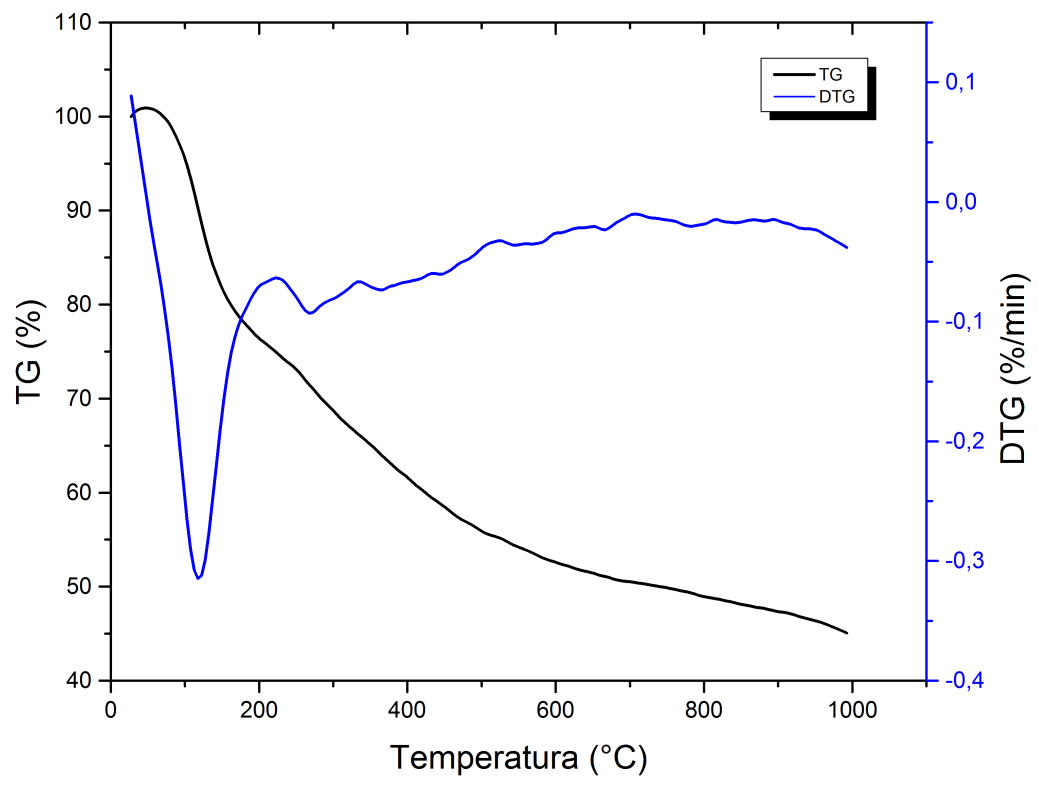


Conforme se pode observar na Figura 4.3, a partir dos 400 até $1000{ }^{\circ} \mathrm{C}$ o material continua a perder massa provavelmente devido à queima de material carbonoso residual somado aos processos de desidratação do $\mathrm{CaSO}_{4} \cdot 2 \mathrm{H}_{2} \mathrm{O}\left(>600^{\circ} \mathrm{C}\right)$ e decomposição do $\mathrm{CaSO}_{4}$ para CaS que ocorre a temperaturas a partir dos 850 até $950{ }^{\circ} \mathrm{C}$ (SWIFT et al., 1976). A presença de picos pouco definidos pode ser explicada pela sobreposição das reações descritas acima. A decomposição do CaS não foi observada nestas curvas de análises térmicas, devido ao fato de sua decomposição térmica ocorrer somente a partir dos 950 até $1100^{\circ} \mathrm{C}$ (SWIFT et al., 1976).

\subsubsection{Determinação do teor de carbono, hidrogênio, nitrogênio e umidade}

$\mathrm{Na}$ Tabela 4.4 são apresentados os resultados da análise elementar de carbono, hidrogênio, nitrogênio, enxofre e teor de umidade do lodo estudado (lodo B) junto com os resultados encontrados em outros trabalhos. Na mesma tabela são apresentados também os resultados de análise elementar do coque de petróleo que será utilizado como agente redutor na fabricação dos vidros sodo-cálcicos. Os resultados mostram que os valores de $\mathrm{C}, \mathrm{N}$ e $\mathrm{S}$ do lodo de cromo estudado são próximos aos valores reportados por Abreu (2006). Estas semelhanças podem ser explicadas pelo fato deste lodo também ter sido coletado em alguma empresa curtidora do município de Franca que provavelmente utilize um processo semelhante ao da empresa onde o lodo estudado foi coletado. Foram observadas também variações nos teores de umidade destes dois resíduos, provavelmente devido a diferenças nas condições de secagem e armazenamento. Comparando os resultados obtidos para o lodo $B$ com os resultados reportados por Shen et al. (2003), podemos observar diferenças mais significativas que, como já foi comentando anteriormente, podem estar associadas à utilização de diferentes insumos e processos durante a fabricação do couro e no processo tratamento dos efluentes.

Tabela 4.4 - Composição elementar de C, H, N, S e teor de umidade do lodo de cromo estudado comparado aos resultados reportados por outros autores.

\begin{tabular}{lccccc}
\hline Amostra & \multicolumn{4}{c}{ Porcentagem em massa (\%) } \\
& Umidade & Carbono & Hidrogênio & Nitrogênio & Enxofre \\
\hline Lodo B & 3,83 & 6,25 & 4,28 & 1,18 & 2,66 (FRX) \\
Abreu (2006) & 9,57 & 5,99 & & 1,10 & 3,67 \\
Shen et al. (2003) & & 14,96 & & 1,35 & $<0,5$ \\
Coque de petróleo & & 90,13 & 0,45 & 0,40 & \\
\hline
\end{tabular}




\subsubsection{Determinação da distribuição de tamanho de partícula}

Na Figura 4.4 são apresentadas as curvas de distribuição granulométrica das matériasprimas (areia, barrilha e calcário) utilizadas para a preparação das amostras de vidros. Os diâmetros médios obtidos, considerando o menor valor dentre os diâmetros máximos medidos nas distintas orientações, foram 272,0 $\mu \mathrm{m}, 355,5 \mu \mathrm{m}$ e 433,6 $\mu \mathrm{m}$ para a areia, barrilha e calcário, respectivamente. Na Figura 4.5 são apresentadas as curvas de distribuição granulométrica do lodo cromo estudado (lodo B) e da cromita (tradicional fonte de cromo utilizada na produção de vidros sodo-cálcicos).

Figura 4.4 - Distribuição de tamanho de partícula das matérias-primas utilizadas para a fabricação dos vidros.

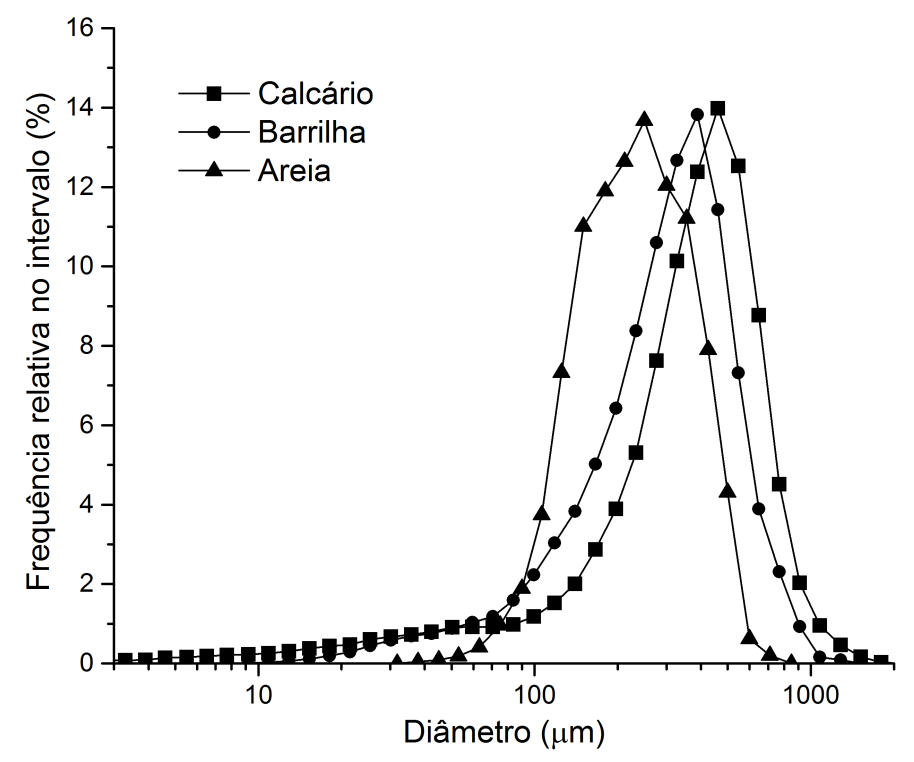

Figura 4.5 - Distribuição de tamanho de partícula do lodo de cromo e da cromita.

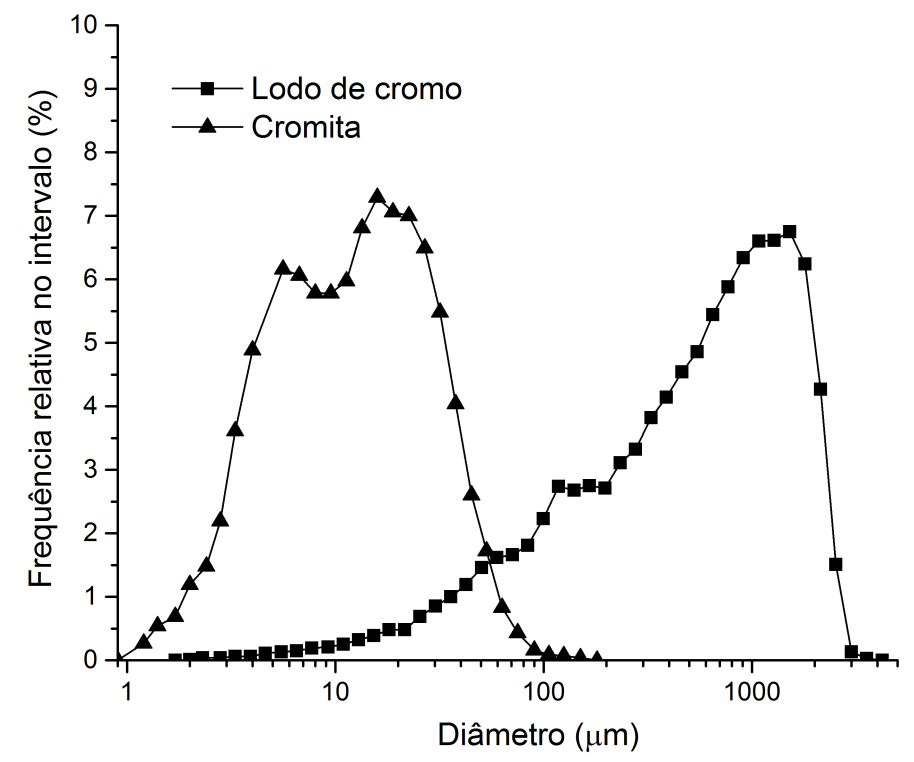


$\mathrm{Na}$ Figura 4.5 pode-se observar que a cromita fornecida apresenta tamanhos de partícula menores do que os observados nas matérias-primas (areia, barrilha e calcário), com um tamanho médio de partícula de 17,6 $\mu \mathrm{m}$. Na fabricação industrial de vidros, a cromita é comumente utilizada em granulometrias finas, como a observada na Figura 4.5, principalmente com o objetivo de facilitar a dispersão do cromo na matriz vítrea e assim evitar a formação de infundidos no vidro, causados pela baixa solubilidade do $\mathrm{Cr}_{2} \mathrm{O}_{3}$ nos vidros silicatos (BRILL, 1980). Na Figura 4.5 pode-se observar também que o lodo de cromo apresenta tamanhos de partícula maiores do que a cromita, com um diâmetro médio de partícula de $827,4 \mu \mathrm{m}$. É importante mencionar que o lodo de cromo estudado no presente trabalho não foi moído em granulometrias mais finas a fim de minimizar os riscos de exposição ao cromo e facilitar a manipulação das amostras.

\subsubsection{Determinação do poder calorífico e teor de cinzas}

$\mathrm{Na}$ Tabela 4.5 são apresentados os valores de PCS e PCl obtidos pelos métodos da bomba calorimétrica e pela fórmula modificada de Dulong. Pode-ser observar que ambos resultados apresentam um valor próximo, o que mostra que é possível obter valores aproximados do poder calorífico a partir da análise elementar do resíduo, utilizando a fórmula modificada de Dulong. O valor de $\mathrm{PCl}$ do lodo de cromo, de 901,1 kcal/kg, está abaixo do valor necessário para auto-sustentar sua combustão (5000 kcal/kg) sem a necessidade do uso de um combustível adicional (JACKMAN; POWELL, 1991). No entanto, alguns resíduos com baixos valores de $\mathrm{PCl}$ podem ser incinerados em conjunto com outros resíduos, provenientes de atividades agrícolas ou industriais, que apresentam valores de $\mathrm{PCl}$ superiores (co-incineração). As aparas de couro são resíduos sólidos abundantes, provenientes da indústria de couro, que apresentam valores consideráveis de $\mathrm{PCl}$ (ao redor de $4000 \mathrm{kcal} / \mathrm{kg}$ ) e altos teores de cromo (ao redor de $50 \%$ de $\mathrm{Cr}_{2} \mathrm{O}_{3}$ em massa) na composição das suas cinzas decorrentes da incineração (COSTA, 2009; GODINHO, 2006). Estas características tornam este resíduo uma alternativa de grande potencial para ser incinerado em conjunto com o lodo de cromo a fim de melhorar a combustão dos resíduos e possibilitar a recuperação de cromo.

Tabela 4.5 - Valores de PCS, PCI e teor de cinza do lodo de cromo.

\begin{tabular}{lccc}
\hline & PCS $(\mathrm{kcal} / \mathrm{kg})$ & $\mathrm{PCl}(\mathrm{kcal} / \mathrm{kg})$ & teor de cinzas $(\%)$ \\
\hline Bomba calorimétrica & 1118,0 & 901,1 & 52,0 \\
Fórmula de Dulong & 1208,3 & 991,4 & \\
\hline
\end{tabular}




\subsubsection{Determinação das espécies de cromo}

$\mathrm{Na}$ Tabela 4.6 são apresentadas as concentrações de cromo total e $\mathrm{Cr}(\mathrm{VI})$ presentes no lodo de cromo estudado. O resultado mostrou uma quantidade elevada de $\mathrm{Cr}(\mathrm{III})$ $(10,48 \%)$. Este resultado é próximo ao valor reportado por Shen et al. (2003) (12,8\%) para um lodo de cromo proveniente da indústria de curtume. A presença de $\mathrm{Cr}(\mathrm{VI})$ não foi detectada no lodo de cromo coletado o que sugere que o cromo presente no resíduo se encontra formando compostos de $\mathrm{Cr}(\mathrm{III})$.

Tabela 4.6 - Concentração de cromo total e cromo hexavalente no lodo de cromo.

\begin{tabular}{|c|c|c|}
\hline \multirow[t]{2}{*}{ Amostra } & \multicolumn{2}{|c|}{ Porcentagem em massa $(\%$} \\
\hline & Cr total & $\mathrm{Cr}(\mathrm{VI})$ \\
\hline Lodo de cromo & 10,48 & n.d. \\
\hline
\end{tabular}

\subsubsection{Microscopia Eletrônica de Varredura (MEV) e Espectroscopia de Energia Dispersiva (EDS)}

A análise das imagens de MEV do lodo de cromo mostrou que o resíduo apresenta a forma de agregados irregulares, constituídos por partículas mais finas, sem morfologia definida. Foi observada também a presença de filamentos incrustados nos agregados, como pode ser observado com mais detalhe na Figura 4.6. As microanálises químicas por EDS realizadas no agregado (ponto 1) e no filamento (ponto 2) revelaram que o agregado apresenta um maior teor de cromo (38\%) do que o observado no filamento $(15,51 \%)$. Além disso, o filamento apresenta um alto teor de carbono e oxigênio na sua composição o que pode indicar que os filamentos presentes no resíduo correspondam a pequenos pedaços de couro curtido residual.

A microanálise do agregado (ponto 2) revelou a presença de uma considerável quantidade de $\mathrm{Ca}(25,66 \%)$, a qual pode estar associada à utilização de hidróxido de cálcio como agente floculante durante o processo de tratamento de efluentes. Além do $\mathrm{Cr}$ e $\mathrm{Ca}$, pequenas quantidades de $\mathrm{Si}, \mathrm{Na}, \mathrm{Mg}, \mathrm{S}, \mathrm{P}$ e $\mathrm{Cl}$ também foram encontradas no agregado. A composição química detalhada dos pontos analisados por EDS é apresentada na Tabela 4.7. 
Figura 4.6 - Micrografia e microanálise por EDS do lodo de cromo.
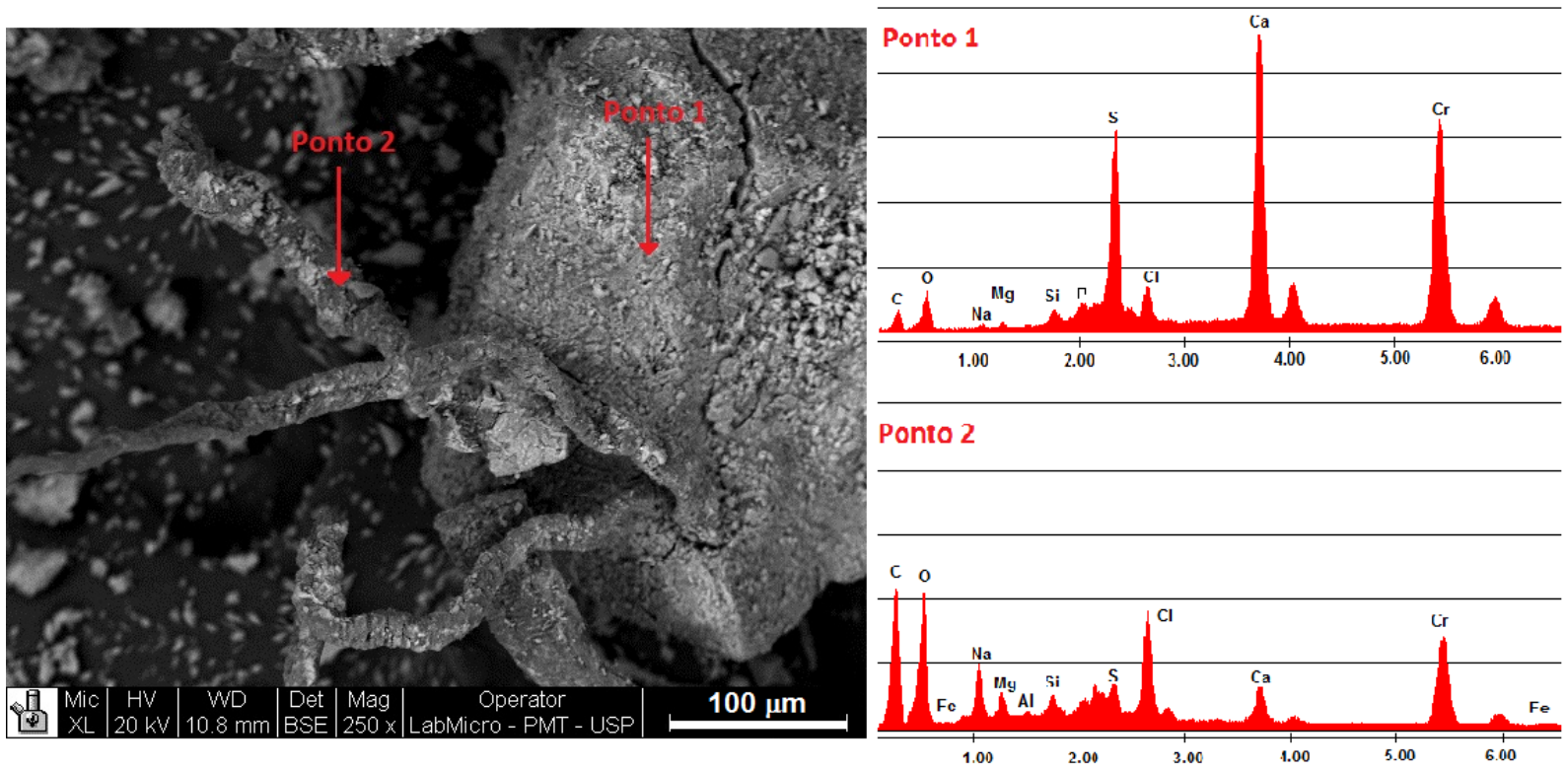

Com o intuito de comparar os resultados de microanálise química por EDS com os resultados obtidos por FRX, foram analisadas duas áreas de diferentes agregados do lodo de cromo. As micrografias são apresentadas na Figura 4.7. As composições químicas de microanálise por EDS são apresentadas na Tabela 4.7. Os resultados mostraram que as áreas analisadas apresentam elevados teores de cromo (22,50\% na área 1 e 35,71\% na área 2), além de pequenas proporções de $\mathrm{Si}, \mathrm{Na}, \mathrm{Ca}, \mathrm{Mg}, \mathrm{S}, \mathrm{P}$ e $\mathrm{Cl}$. Conforme pode ser observado na Tabela 4.7, os resultados de microanálise por EDS são coerentes com os resultados obtidos por $\mathrm{FRX}$.

Figura 4.7 - Micrografias do lodo indicando as áreas microanalisadas por EDS.
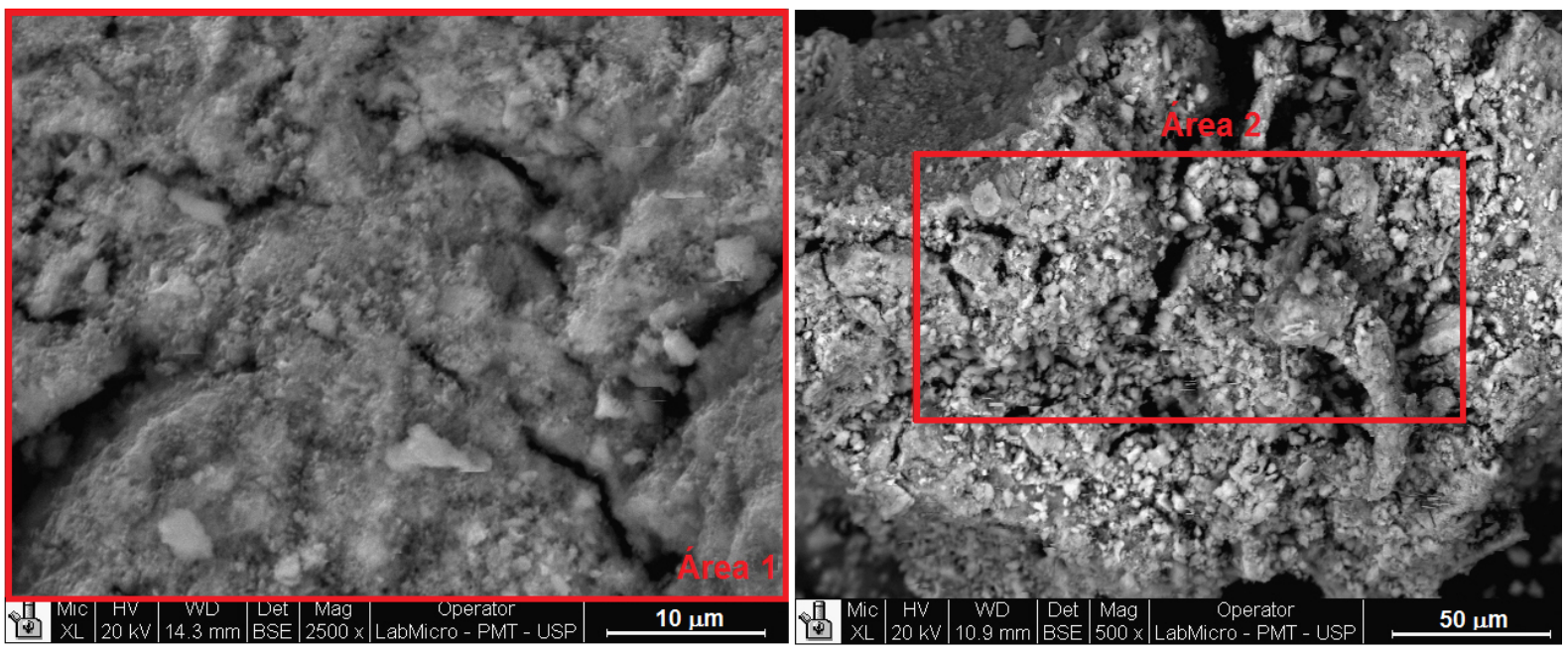
Tabela 4.7 - Composição química por FRX e microanálise química por EDS do lodo de cromo.

\begin{tabular}{|c|c|c|c|c|c|c|c|}
\hline \multicolumn{4}{|c|}{ FRX (\% em massa) } & \multicolumn{4}{|c|}{ EDS (\% em massa) } \\
\hline Óxidos & Lodo B & Elementos & Lodo B & Área 1 & Área 2 & Ponto 1 & Ponto 2 \\
\hline $\mathrm{SiO}_{2}$ & 2,07 & $\mathrm{Si}$ & 0,97 & 1,96 & 2,47 & 1,01 & 0,96 \\
\hline $\mathrm{Al}_{2} \mathrm{O}_{3}$ & 0,40 & $\mathrm{Al}$ & 0,21 & & 0,87 & & 0,19 \\
\hline $\mathrm{Na}_{2} \mathrm{O}$ & 2,78 & $\mathrm{Na}$ & 2,06 & 4,97 & 3,58 & 0,58 & 4,28 \\
\hline $\mathrm{K}_{2} \mathrm{O}$ & 0,04 & $\mathrm{~K}$ & 0,03 & & & & \\
\hline $\mathrm{CaO}$ & 6,87 & $\mathrm{Ca}$ & 4,92 & 5,43 & 6,42 & 25,66 & 3,11 \\
\hline $\mathrm{MgO}$ & 2,46 & $\mathrm{Mg}$ & 1,48 & 2,62 & 2,40 & 0,50 & 1,63 \\
\hline $\mathrm{Cr}_{2} \mathrm{O}_{3}$ & 37,56 & $\mathrm{Cr}$ & 25,70 & 22,50 & 35,71 & 38,08 & 15,21 \\
\hline $\mathrm{Fe}_{2} \mathrm{O}_{3}$ & 1,03 & $\mathrm{Fe}$ & 0,72 & & 1,04 & & 0,82 \\
\hline $\mathrm{TiO}_{2}$ & 0,03 & $\mathrm{Ti}$ & 0,02 & & & & \\
\hline $\mathrm{V}_{2} \mathrm{O}_{5}$ & & V & & & & & 0,10 \\
\hline $\mathrm{NiO}$ & 0,07 & $\mathrm{Ni}$ & 0,06 & & & & \\
\hline $\mathrm{CuO}$ & 0,01 & $\mathrm{Cu}$ & 0,01 & & & & \\
\hline $\mathrm{ZnO}$ & 0,03 & $\mathrm{Zn}$ & 0,02 & & & & \\
\hline SrO & 0,05 & $\mathrm{Sr}$ & 0,04 & & & & \\
\hline $\mathrm{PbO}$ & 0,01 & $\mathrm{~Pb}$ & 0,01 & & & & \\
\hline $\mathrm{SO}_{3}$ & 6,63 & $\mathrm{~S}$ & 2,66 & 1,41 & 3,16 & 11,30 & 1,87 \\
\hline $\mathrm{P}_{2} \mathrm{O}_{5}$ & 2,27 & $P$ & 0,99 & 1,50 & 1,86 & 1,57 & \\
\hline \multirow[t]{3}{*}{$\mathrm{Cl}$} & 4,03 & $\mathrm{Cl}$ & 4,03 & 3,04 & 3,61 & 2,64 & 6,24 \\
\hline & & $C$ & & 24,13 & 19,79 & 9,51 & 43,50 \\
\hline & & $\mathrm{O}$ & & 32,45 & 19,08 & 9,16 & 22,10 \\
\hline PF & 33,67 & & & & & & \\
\hline Total & 100 & & & 100,01 & 99,99 & 100,01 & 100,01 \\
\hline
\end{tabular}

\subsection{Caracterização das cinzas}

\subsubsection{Composição química por FRX}

Na Tabela 4.8 é apresentada a composição química, expressa em óxidos e elementos, das cinzas provenientes da incineração do lodo de cromo a $800^{\circ} \mathrm{C}$. Na Tabela 4.8 foram incluídos também os resultados da análise química da cromita apresentados na seção 4.1.1, a fim de realizar comparações entre as cinzas da incineração do lodo e a cromita. A análise química revelou que as cinzas contêm a redor de 46,98\% de $\mathrm{Cr}_{2} \mathrm{O}_{3}$ na sua composição, valor levemente superior ao teor de cromo observado na cromita $(42,68 \%$ $\mathrm{Cr}_{2} \mathrm{O}_{3}$ ). Este resultado mostra o potencial deste resíduo para ser utilizado como uma fonte alternativa de $\mathrm{Cr}_{2} \mathrm{O}_{3}$ para a indústria de fabricação de vidros sodo-cálcicos e outras indústrias que utilizam cromo nos seus processos (indústria química, metalúrgica e de refratários). 
Tabela 4.8 - Composição química por FRX da cromita e das cinzas provenientes da incineração do lodo de cromo.

\begin{tabular}{lcc|lcc}
\hline \multicolumn{5}{c}{ Porcentagem em massa (\%) } \\
Óxidos & Cromita & Cinzas do lodo B & Elementos & Cinzas do lodo B \\
\hline $\mathrm{SiO}_{2}$ & 9,86 & 3,54 & $\mathrm{Si}$ & 1,65 \\
$\mathrm{Al}_{2} \mathrm{O}_{3}$ & 12,32 & 0,64 & $\mathrm{Al}$ & 0,34 \\
$\mathrm{Na}_{2} \mathrm{O}$ & 0,12 & 6,28 & $\mathrm{Na}$ & 4,66 \\
$\mathrm{~K}_{2} \mathrm{O}$ & 0,04 & 0,06 & $\mathrm{~K}$ & 0,05 \\
$\mathrm{CaO}$ & 0,76 & 10,18 & $\mathrm{Ca}$ & 7,28 \\
$\mathrm{MgO}$ & 15,73 & 4,27 & $\mathrm{Mg}$ & 2,57 \\
$\mathrm{Cr}_{2} \mathrm{O}_{3}$ & 42,68 & 46,98 & $\mathrm{Cr}$ & 32,15 \\
$\mathrm{Fe}_{2} \mathrm{O}_{3}$ & 17,93 & 1,40 & $\mathrm{Fe}$ & 0,98 \\
$\mathrm{TiO}_{2}$ & 0,31 & 0,04 & $\mathrm{Ti}$ & 0,02 \\
$\mathrm{NiO}$ & 0,01 & 0,10 & $\mathrm{Ni}$ & 0,08 \\
$\mathrm{CuO}$ & & 0,01 & $\mathrm{Cu}$ & 0,01 \\
$\mathrm{ZnO}$ & 0,05 & 0,10 & $\mathrm{Zn}$ & 0,08 \\
$\mathrm{SrO}_{\mathrm{SO}}$ & & 0,06 & $\mathrm{Sr}$ & 0,05 \\
$\mathrm{P}_{2} \mathrm{O}_{5}$ & 0,03 & 7,20 & $\mathrm{~S}$ & 2,88 \\
$\mathrm{Cl}$ & 0,01 & 3,71 & $\mathrm{P}$ & 1,62 \\
$\mathrm{Br}$ & 0,02 & 4,72 & $\mathrm{Cl}$ & 4,72 \\
$\mathrm{PF}\left(1050{ }^{\circ} \mathrm{C}\right)$ & & 0,01 & $\mathrm{Br}$ & 0,01 \\
\hline $\mathrm{Total}$ & 100,00 & 10,70 & & 10,70 \\
\hline
\end{tabular}

Na Tabela 4.8 pode-se observar também que as cinzas apresentam um considerável teor de perda ao fogo (10,70\%), que provavelmente corresponde à queima de material carbonoso residual e à decomposição térmica do $\mathrm{CaS}\left(950^{\circ} \mathrm{C}\right.$ até $\left.1100^{\circ} \mathrm{C}\right)$ que não foi alcançada no processo de incineração do lodo, já que a temperatura máxima alcançada na incineração foi de $800^{\circ} \mathrm{C}$.

$\mathrm{Na}$ Tabela 4.9 são apresentadas as composições químicas das cinzas provenientes da incineração de outros tipos de resíduos provenientes da indústria de fabricação de couro, em sua maioria aparas de couro curtido ("wet-blue") ou misturas de aparas de couro, serragem e pós de couro curtido. Comparando estes resultados aos dados apresentados na Tabela 4.8 podemos observar que os teores de $\mathrm{Cr}_{2} \mathrm{O}_{3}$ presentes nas cinzas das aparas de couro apresentam valores próximos aos observados nas cinzas do lodo de cromo. Por outro lado, os resultados obtidos pelas técnicas de ICP, AAS e EDS apresentam uma variabilidade maior, provavelmente devido à influência de vários fatores, tais como o tipo de resíduo, o processo de incineração e a técnica de análise empregada. Contudo, estes resíduos apresentaram importantes teores de cromo, de 29,4\%, 59,4\% e $16,57 \%$, equivalentes a $42,97 \%, 86,8 \%$ e $24,22 \%$ de $\mathrm{Cr}_{2} \mathrm{O}_{3}$, respectivamente. 
Tabela 4.9 - Composição química das cinzas resultantes da incineração a diferentes temperaturas de outros resíduos sólidos provenientes da indústria de fabricação de couro.

\begin{tabular}{|c|c|c|c|c|c|c|c|}
\hline \multicolumn{8}{|c|}{ Porcentagem em massa $(\%)$} \\
\hline Óxidos & $\begin{array}{l}\text { Mistura de } \\
\text { resíduos a }^{\text {a }}\end{array}$ & $\begin{array}{l}\text { Aparas } \\
\text { de couro } \\
900{ }^{\circ} \mathrm{C}\end{array}$ & $\begin{array}{c}\text { Aparas } \\
\text { de couro } \\
900{ }^{\circ} \mathrm{C}\end{array}$ & Elementos & $\begin{array}{l}\text { Aparas } \\
\text { de couro } \\
800^{\circ} \mathrm{C}\end{array}$ & $\begin{array}{l}\text { Aparas } \\
\text { de couro } \\
650{ }^{\circ} \mathrm{C}\end{array}$ & $\begin{array}{c}\text { Aparas } \\
\text { de couro } \\
900{ }^{\circ} \mathrm{C}\end{array}$ \\
\hline $\mathrm{SiO}_{2}$ & 9,96 & 23,58 & 12,00 & $\mathrm{Si}$ & 1,80 & & 2,12 \\
\hline $\mathrm{Al}_{2} \mathrm{O}_{3}$ & 6,59 & 7,35 & 6,70 & $\mathrm{Al}$ & 1,50 & 3,50 & 0,90 \\
\hline $\mathrm{Na}_{2} \mathrm{O}$ & & 1,08 & 5,30 & $\mathrm{Na}$ & 8,00 & & 3,47 \\
\hline $\mathrm{K}_{2} \mathrm{O}$ & 0,86 & 0,79 & & $\mathrm{~K}$ & 0,33 & & 0,07 \\
\hline $\mathrm{CaO}$ & 4,43 & 1,20 & 1,00 & $\mathrm{Ca}$ & 2,40 & 1,30 & 1,80 \\
\hline $\mathrm{MgO}$ & & & & $\mathrm{Mg}$ & 19,00 & & 0,15 \\
\hline $\mathrm{Cr}_{2} \mathrm{O}_{3}$ & 62,29 & 55,91 & 68,00 & $\mathrm{Cr}$ & 29,40 & 59,40 & 16,57 \\
\hline $\mathrm{Fe}_{2} \mathrm{O}_{3}$ & 2,31 & 2,59 & & $\mathrm{Fe}$ & 1,90 & 1,70 & 36,50 \\
\hline $\mathrm{TiO}_{2}$ & 8,41 & 1,53 & 0,80 & $\mathrm{Ti}$ & 0,04 & & 1,57 \\
\hline $\mathrm{CuO}$ & 0,06 & & & $\mathrm{Cu}$ & & & \\
\hline ZnO & & & & $\mathrm{Zn}$ & & & 0,93 \\
\hline $\mathrm{MnO}$ & & & & $\mathrm{Mn}$ & 0,07 & & \\
\hline $\mathrm{SO}_{3}$ & 2,33 & 2,81 & 2,50 & $S$ & & 0,30 & \\
\hline $\mathrm{P}_{2} \mathrm{O}_{5}$ & 2,58 & 1,59 & 3,60 & $P$ & 0,30 & & 0,03 \\
\hline $\mathrm{Cl}$ & 0,01 & 0,72 & & $\mathrm{Cl}$ & & & \\
\hline & & & & $\mathrm{O}$ & & & 35,71 \\
\hline P.F. & & & & P.F. & 17,00 & & \\
\hline Total & 99,82 & 99,15 & 99,90 & & & & \\
\hline
\end{tabular}

Fontes:

a Wenzel et al. (2010), resultado determinado por FRX.

${ }^{b}$ Godinho (2006), resultado determinado por FRX.

c Medes, Gibim e Toffoli (2011), resultado determinado por FRX.

d Basegio et al. (2009), resultado determinado por ICP.

e Alves, Heck e Schneider (2009), resultado obtido por Espectrometria de Absorção Atômica (AAS).

${ }^{f}$ Fernandes e Ferreira (2007), resultado determinado por EDS.

\subsubsection{Determinação da distribuição de tamanho de partícula}

Na Figura 4.8 são apresentadas as curvas de distribuição de tamanho de partícula da cromita e do resíduo estudado antes (lodo de cromo) e depois do processo de incineração (cinzas do lodo de cromo). Conforme se pode observar nesta figura, os agregados de lodo de cromo apresentaram uma considerável diminuição no seu tamanho de partícula devido ao processo de incineração. Isto pode ser identificado pelo deslocamento para a esquerda da sua curva de distribuição granulométrica após a incineração. As cinzas, produto da incineração do lodo de cromo, e o lodo de cromo apresentaram, respectivamente, diâmetros médios de 499,3 $\mu \mathrm{m}$ e 827,4 $\mu \mathrm{m}$. 
Figura 4.8 - Comparação das distribuições granulométricas das cinzas provenientes da incineração com o lodo de cromo e a cromita.

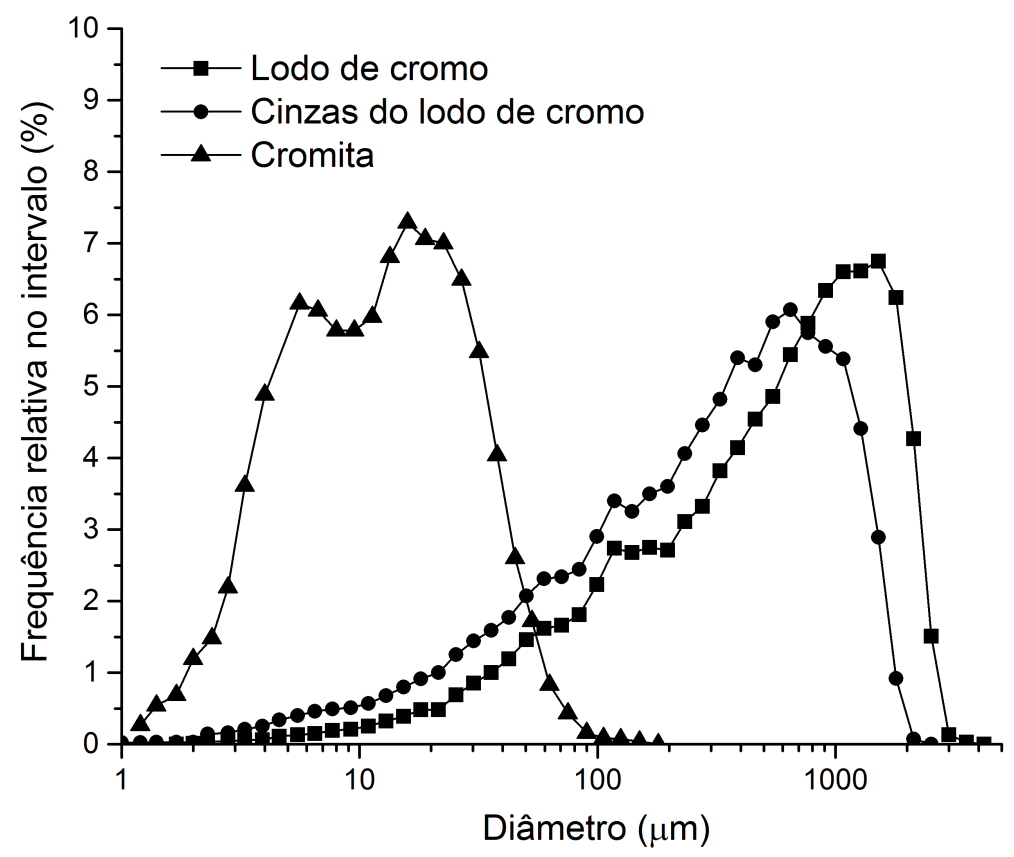

Comparando as curvas de distribuição granulométrica apresentadas na Figura 4.8 podemos observar que, apesar da incineração do resíduo ter causado uma diminuição significativa no tamanho de partícula do lodo de cromo, a granulometria das cinzas é ainda grande comparada com a granulometria da cromita, que apresenta um tamanho médio de partícula de 17,6 $\mu \mathrm{m}$. Sendo assim, foi necessário diminuir a granulometria das cinzas da incineração do lodo cromo, usando um almofariz, para granulometrias mais finas a fim de facilitar a dispersão das cinzas do resíduo na matriz vítrea.

\subsubsection{Determinação das espécies de cromo}

$\mathrm{Na}$ Tabela 4.10 são apresentadas as concentrações de cromo total e $\mathrm{Cr}(\mathrm{VI})$ presentes nas cinzas provenientes da incineração do lodo de cromo estudado. Adicionalmente, foram incluídas também as concentrações de $\mathrm{Cr}(\mathrm{VI})$ presentes nas cinzas da incineração de outros resíduos da indústria do couro. As cinzas do resíduo estudado apresentaram uma concentração de $0,51 \%$ em massa de $\mathrm{Cr}(\mathrm{VI})$, o que indicaria a formação de compostos de $\mathrm{Cr}(\mathrm{VI})$ a partir dos compostos de $\mathrm{Cr}(\mathrm{III})$ durante o processo de incineração. A concentração de $\mathrm{Cr}(\mathrm{VI})$ observada nas cinzas do resíduo estudado é inferior aos valores reportados por Abreu (2006), provavelmente devido às diferentes metodologias empregadas assim como devido à variabilidade do resíduo. 
Tabela 4.10 - Concentração de espécies de cromo das cinzas da incineração de lodo cromo e aparas de couro.

\begin{tabular}{|c|c|c|}
\hline \multirow[t]{2}{*}{ Amostra } & \multicolumn{2}{|c|}{ Porcentagem em massa (\%) } \\
\hline & Cr total & $\mathrm{Cr}(\mathrm{VI})$ \\
\hline Cinzas do lodo de cromo $\left(800^{\circ} \mathrm{C}\right)$ & 8,08 & 0,51 \\
\hline Cinzas do lodo de cromo $\left(700^{\circ} \mathrm{C}\right)^{\mathrm{a}}$ & & 1,036 \\
\hline Cinzas do lodo de cromo $\left(1150^{\circ} \mathrm{C}\right)^{\mathrm{a}}$ & & 5,825 \\
\hline Cinzas das aparas de couro $\left(780^{\circ} \mathrm{C}\right)^{\mathrm{b}}$ & 5,49 & 0,044 \\
\hline Cinzas das aparas de couro $\left(830^{\circ} \mathrm{C}\right)^{\mathrm{b}}$ & 7,68 & 0,204 \\
\hline Cinzas das aparas de couro $\left(850^{\circ} \mathrm{C}\right)^{\mathrm{b}}$ & 35,10 & 0,105 \\
\hline
\end{tabular}

Fontes:

a Abreu (2006), resultado obtido por eletroforese capilar.

${ }^{b}$ Martins (2001), resultado obtido pelo método espectrofotométrico-DPC.

$\mathrm{Na}$ Tabela 4.10 foram incluídas também as concentrações de $\mathrm{Cr}(\mathrm{VI})$ das cinzas da incineração de aparas de couro, obtidas num reator de leito fluidizado, reportadas por Martins (2001). Pode-se observar que estas cinzas apresentam concentrações consideravelmente mais baixas do que as observadas nas cinzas do resíduo estudado, provavelmente devido às condições do processo de incineração. Estes resultados sugerem que, sob condições adequadas, as cinzas provenientes da incineração do lodo de cromo também podem apresentar concentrações mais baixas de $\mathrm{Cr}(\mathrm{VI})$.

\subsection{Caracterização dos vidros}

\subsubsection{Composição química por FRX}

$\mathrm{Na}$ Tabela 4.11 são apresentadas as composições químicas dos vidros sodo-cálcicos preparados utilizando cromita (típica fonte industrial de cromo usada na fabricação de vidros verdes) e as cinzas da incineração do lodo de cromo como fontes de cromo e hematita como fonte de ferro. Os resultados da análise química mostraram que as composições reais dos vidros preparados são próximas às composições nominais descritas na Tabela 3.1 da seção 3.3.3. Todas as amostras de vidro preparadas apresentaram uma cor verde homogênea, textura superficial lisa, e a presença ocasional de bolhas visíveis. Algumas amostras apresentaram a presença de um material de coloração branca na superfície do vidro (Figura 4.9), localizado principalmente ao redor das superfícies em contato com o cadinho de alumina. Este material provavelmente corresponde à mistura de matéria-prima que ficou presa na superfície do cadinho durante o processo de fusão e que esteve em contato direto com a massa de vidro fundido por um tempo menor. 
Tabela 4.11 - Composição química dos vidros sodo-cálcicos preparados utilizando cromita, cinzas da incineração do lodo de cromo e hematita.

\begin{tabular}{lcccc}
\hline Óxidos & \multicolumn{4}{c}{ Porcentagem em massa (\%) } \\
& Cromita $\mathrm{R}$ & Cromita+hematita $\mathrm{R}$ & Cinzas R & Cinzas+hematita R \\
\hline $\mathrm{SiO}_{2}$ & 75,71 & 72,73 & 75,73 & 73,77 \\
$\mathrm{Al}_{2} \mathrm{O}_{3}$ & 0,81 & 1,11 & 1,05 & 1,08 \\
$\mathrm{Na}_{2} \mathrm{O}$ & 10,23 & 11,84 & 9,66 & 11,51 \\
$\mathrm{~K}_{2} \mathrm{O}$ & 0,01 & 0,01 & 0,01 & 0,01 \\
$\mathrm{CaO}$ & 12,74 & 13,54 & 13,04 & 12,91 \\
$\mathrm{MgO}$ & 0,08 & 0,10 & 0,05 & 0,07 \\
$\mathrm{Cr}_{2} \mathrm{O}_{3}$ & 0,14 & 0,12 & 0,14 & 0,15 \\
$\mathrm{Fe}_{2} \mathrm{O}_{3}$ & 0,11 & 0,36 & 0,07 & 0,32 \\
$\mathrm{TiO}_{2}$ & 0,02 & 0,02 & 0,02 & \\
$\mathrm{ZrO}_{2}$ & 0,01 & 0,01 & 0,05 & 0,02 \\
$\mathrm{NiO}$ & 0,01 & 0,01 & & 0,01 \\
$\mathrm{SrO}$ & 0,07 & 0,08 & 0,08 & 0,07 \\
$\mathrm{MnO}$ & 0,01 & & & \\
$\mathrm{SO}_{3}$ & 0,01 & 0,01 & 0,04 & 0,03 \\
$\mathrm{P}_{2} \mathrm{O}_{5}$ & 0,02 & 0,02 & 0,03 & 0,03 \\
$\mathrm{Cl}$ & 0,02 & 0,01 & 0,04 & 0,03 \\
\hline $\mathrm{Total}$ & 100,00 & 100,00 & 100,00 & 100,00 \\
\hline
\end{tabular}

$\mathrm{Na}$ Tabela 4.11 pode-se observar também que o vidro preparado utilizando cinzas da incineração do lodo de cromo e hematita (identificado como cinzas+hematita R) apresenta uma composição similar à composição do vidro preparado utilizando cromita e hematita (cromita+hematita $\mathrm{R}$ ). Estes resultados sugerem que é possível utilizar as cinzas provenientes da incineração do lodo de cromo como uma fonte alternativa de cromo na formulação e fabricação de vidros sodo-cálcicos.

Figura 4.9 - Matéria-prima residual presente na superfície de algumas amostras dos vidros preparados.

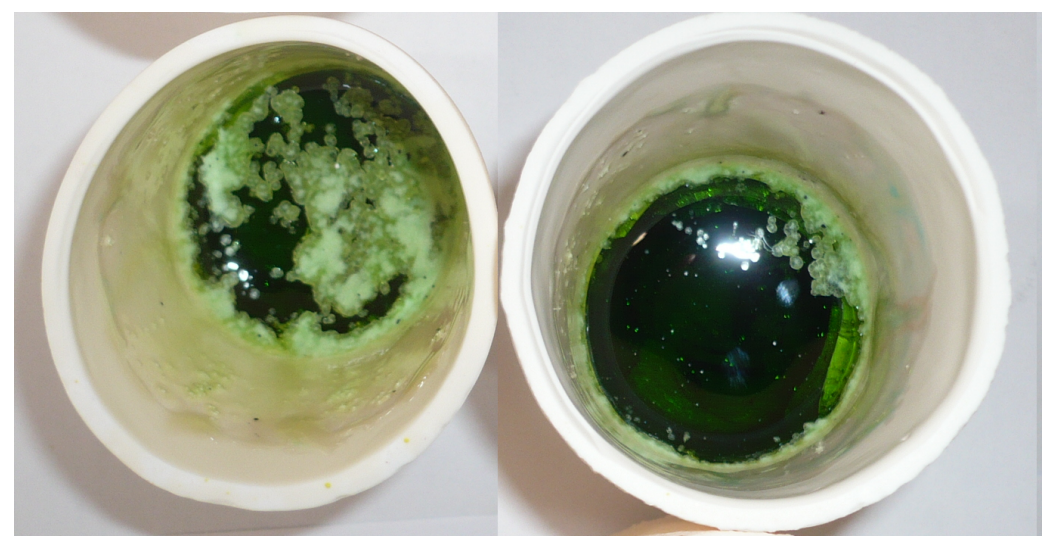


Com o intuito de realizar comparações entre as propriedades dos vidros preparados no presente trabalho e vidros de embalagem comerciais, foram determinadas as composições químicas de quatro vidros de embalagem comerciais (garrafas) utilizados para armazenar cervejas e vinhos, três deles de coloração verde e um de coloração âmbar. As composições químicas dos vidros comerciais são apresentadas na Tabela 4.12. Os resultados da análise química mostraram que os vidros verdes comerciais apresentam teores de $\mathrm{Cr}_{2} \mathrm{O}_{3}$ e $\mathrm{Fe}_{2} \mathrm{O}_{3}$ superiores aos encontrados na bibliografia, de 0,02-0,3\% de $\mathrm{Cr}_{2} \mathrm{O}_{3}$ e 0,02-0,4\% de $\mathrm{Fe}_{2} \mathrm{O}_{3}$ (VOLF, 1984; MILLS; JASINSKI, 1982). Contudo, estes resultados são coerentes e são próximos aos valores $\mathrm{Cr}_{2} \mathrm{O}_{3}$ e $\mathrm{Fe}_{2} \mathrm{O}_{3}$ presentes nos vidros preparados experimentalmente. Na Figura 4.10 são apresentadas as amostras de vidros sodo-cálcicos preparadas experimentalmente utilizando cromita e cinzas da incineração do lodo de cromo como fonte de cromo e hematita como fonte de ferro.

Tabela 4.12 - Composição química das amostras dos vidros de embalagem comerciais utilizados para armazenar cervejas e vinhos.

\begin{tabular}{|c|c|c|c|c|}
\hline \multirow[t]{2}{*}{ Óxidos } & \multicolumn{4}{|c|}{ Porcentagem em massa (\%) } \\
\hline & $\begin{array}{c}\text { Garrafa de cerveja } \\
\text { âmbar }\end{array}$ & $\begin{array}{c}\text { Garrafa de cerveja } \\
\text { verde }\end{array}$ & $\begin{array}{l}\text { Garrafa de vinho } \\
\text { verde claro }\end{array}$ & $\begin{array}{c}\text { Garrafa de vinho } \\
\text { verde escuro }\end{array}$ \\
\hline $\mathrm{SiO}_{2}$ & 72,71 & 71,34 & 69,51 & 68,24 \\
\hline $\mathrm{Al}_{2} \mathrm{O}_{3}$ & 1,25 & 1,48 & 1,92 & 1,25 \\
\hline $\mathrm{Na}_{2} \mathrm{O}$ & 11,33 & 12,61 & 12,45 & 13,15 \\
\hline $\mathrm{K}_{2} \mathrm{O}$ & 0,43 & 0,60 & 0,81 & 0,65 \\
\hline $\mathrm{CaO}$ & 12,64 & 12,11 & 13,36 & 13,25 \\
\hline $\mathrm{MgO}$ & 0,63 & 0,56 & 0,41 & 1,27 \\
\hline $\mathrm{Cr}_{2} \mathrm{O}_{3}$ & 0,03 & 0,38 & 0,41 & 0,31 \\
\hline $\mathrm{Fe}_{2} \mathrm{O}_{3}$ & 0,56 & 0,60 & 0,69 & 1,12 \\
\hline $\mathrm{TiO}_{2}$ & 0,07 & 0,05 & 0,05 & 0,13 \\
\hline $\mathrm{ZrO}_{2}$ & 0,02 & 0,02 & 0,02 & 0,04 \\
\hline $\mathrm{Rb}_{2} \mathrm{O}$ & 0,03 & & 0,01 & \\
\hline $\mathrm{NiO}$ & 0,01 & 0,01 & 0,01 & \\
\hline $\mathrm{CuO}$ & 0,04 & & 0,01 & \\
\hline $\mathrm{ZnO}$ & 0,01 & & 0,01 & 0,01 \\
\hline SrO & 0,07 & 0,06 & 0,08 & 0,12 \\
\hline $\mathrm{PbO}$ & 0,02 & 0,03 & 0,02 & 0,12 \\
\hline $\mathrm{MnO}$ & 0,02 & & 0,02 & 0,03 \\
\hline $\mathrm{BaO}$ & 0,03 & & 0,09 & 0,13 \\
\hline $\mathrm{SO}_{3}$ & 0,05 & 0,09 & 0,05 & 0,08 \\
\hline $\mathrm{P}_{2} \mathrm{O}_{5}$ & 0,03 & 0,03 & 0,03 & 0,03 \\
\hline $\mathrm{Cl}$ & 0,03 & 0,03 & 0,03 & 0,06 \\
\hline Total & 100,00 & 100,00 & 100,00 & 100,00 \\
\hline
\end{tabular}


Figura 4.10 - Amostras dos vidros sodo-cálcicos preparados utilizando cromita, cinzas da incineração do lodo de cromo e hematita.

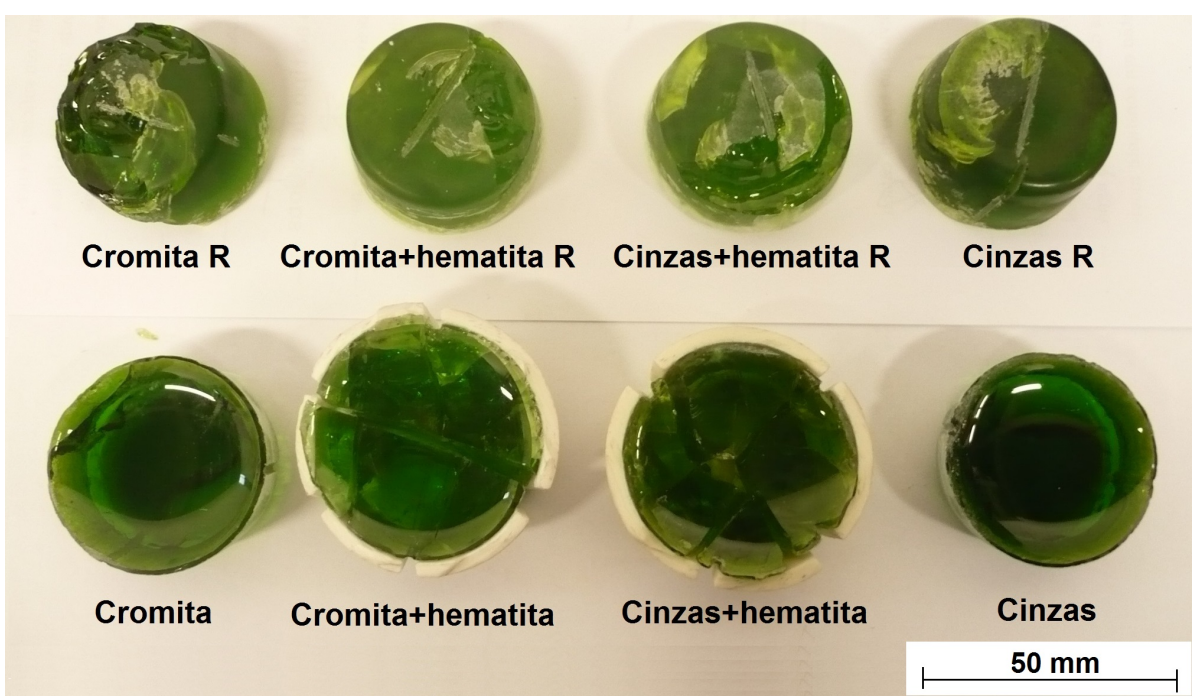

\subsubsection{Microscopia Eletrônica de Varredura (MEV) e Espectroscopia de Energia Dispersiva (EDS)}

Com o intuito de observar a homogeneidade dos vidros assim como a presença de bolhas e infundidos, foi realizada a inspeção visual por MEV e microanálise química por EDS dos vidros sodo-cálcicos preparados experimentalmente. Foram analisadas duas amostras de cada vidro, uma retirada da parte superior do cadinho (superfície) e outra retirada da seção transversal da metade do cadinho.

A inspeção visual das amostras retiradas da parte superficial do vidro revelou a presença ocasional de material infundido de dimensões microscópicas (Figura 4.11-a) em todos os vidros e mais frequentemente nos vidros que apresentaram o material de coloração branca mostrado na Figura 4.9. Não foi possível estabelecer uma relação entre a presença do material infundido observado nos vidros e o tipo de fonte de cromo utilizada (cromita ou cinzas da incineração do lodo de cromo). Não obstante, se consideramos os resultados das fusões preliminares realizadas, podemos observar que a presença de material infundido na superfície do vidro pode estar relacionada às condições do processo de fusão, tais como a temperatura e tempo de permanência no forno, assim como ao formato do cadinho utilizado na fusão. Outra possível causa da presença deste material de coloração branca pode estar relacionada à dissolução da superfície do cadinho de alumina em contato com o vidro fundido e a subsequente formação de infundidos devido à natureza refratária da alumina. 
A inspeção visual das amostras de vidro retiradas da seção transversal do cadinho de alumina revelou a presença de material infundido e microbolhas com diferentes dimensões (Figura 4.11-b e Figura 4.11-c) que apresentam material granulado dentro delas (Figura 4.11-d). Do mesmo modo que nas amostras retiradas da superfície, não foi possível estabelecer uma relação entre os defeitos observados (material infundido e microbolhas) nos vidros e o tipo da fonte de cromo utilizada. Os resultados da microanálise química mostraram que o material infundido e o material granulado observado no interior das bolhas apresentam silício, sódio e cálcio na sua composição e que provavelmente correspondam à mistura das matérias-primas (areia, barrilha e calcário) utilizadas na fabricação dos vidros. Os resultados da microanálise química por EDS são apresentados na Tabela 4.13.

Figura 4.11 - Micrografias dos vidros sodo-cálcicos preparados: material infundido e microbolhas.

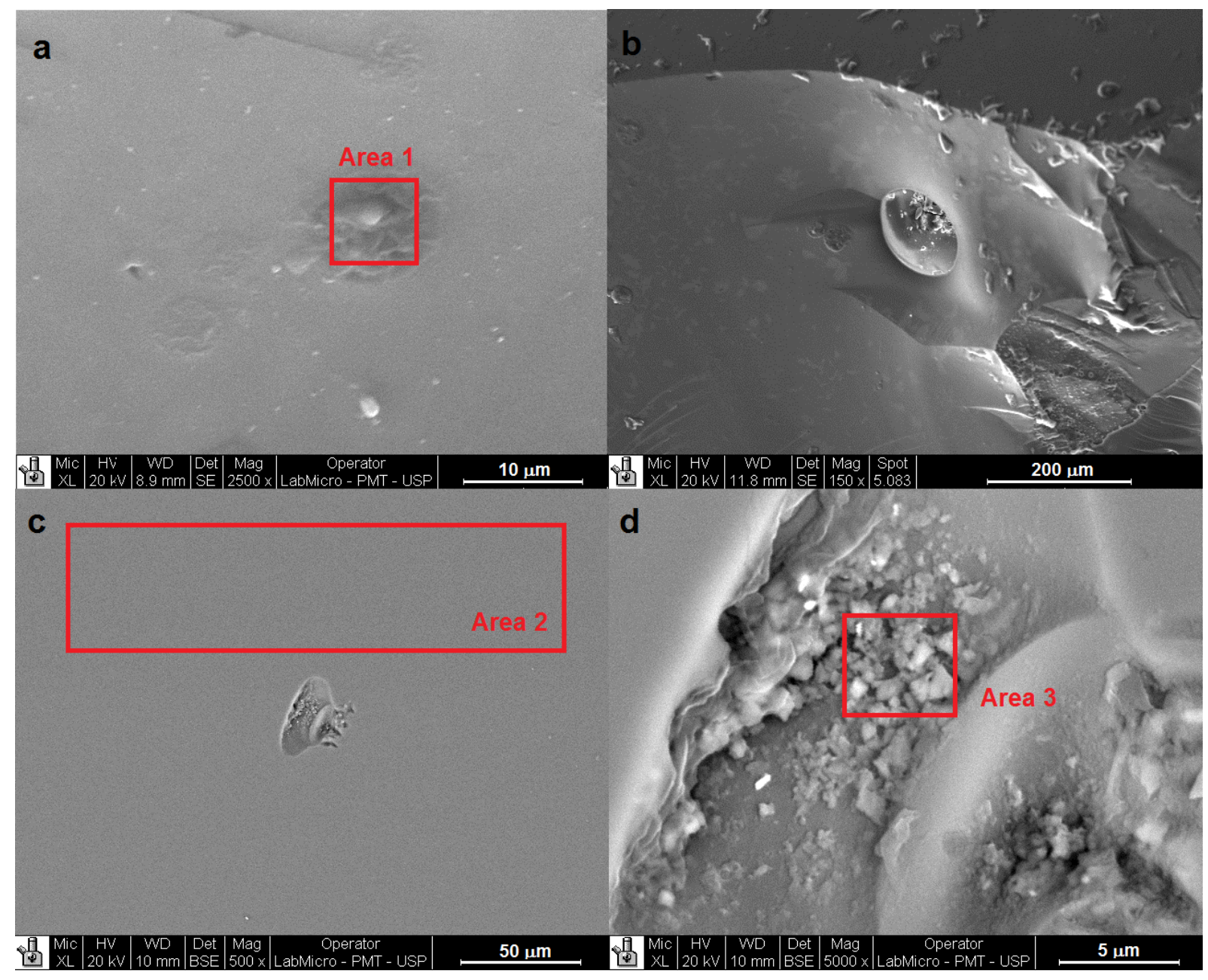


Na Figura 4.12 são apresentadas as micrografias de uma amostra de vidro retirada da parte superficial do vidro que apresentou a presença do material de coloração branca mostrado na Figura 4.9. Pode-se observar que este material apresenta formas definidas que aparentemente correspondem à formação de cristais (Figura 4.12-b), os quais podem ter sido formados a partir de infundidos (matériais-primas que não foram fundidas ou alumina solubilizada proveniente do cadinho) que podem ter atuado como centros de nucleação dos cristais. Os resultados da microanálise química mostraram que estes cristais estão formados principalmente por silício, o que sugere que estes cristais possam ser provavelmente do tipo tridimita $\left(\mathrm{SiO}_{2}\right)$ ou devitrita $\left(\mathrm{Na}_{2} \mathrm{O} .3 \mathrm{CaO} .6 \mathrm{SiO}_{2}\right)$, uma vez que estas fases cristalinas são comumente formadas em vidros do sistema soda-cal-sílica com composições similares às adotadas no presente trabalho (NAVARRO, 2003; ZANOTTO, 1991).

Figura 4.12 - Micrografias e microanálise por EDS dos vidros sodo-cálcicos preparados: material infundido localizado na superfície de algumas amostras.

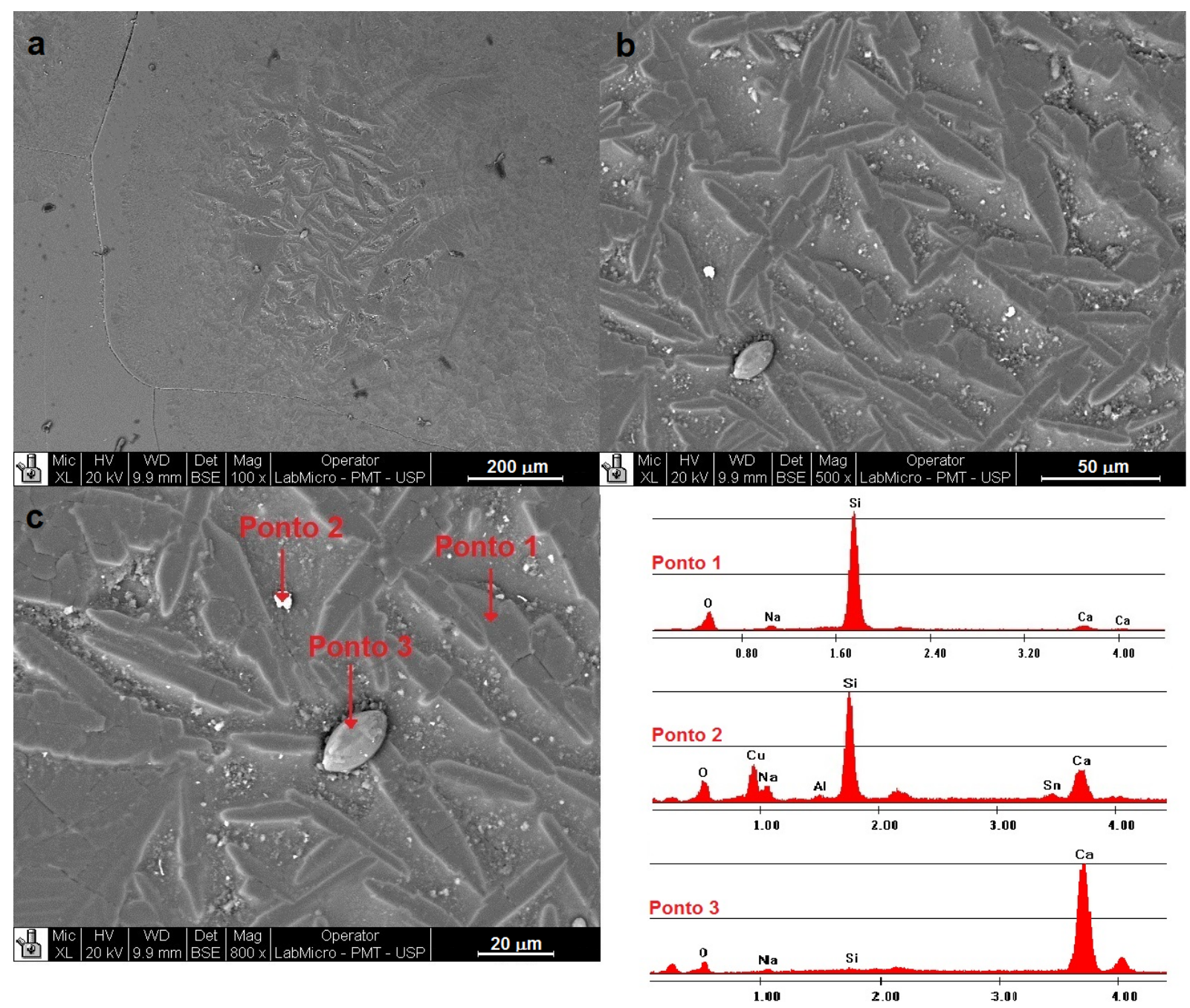


Na Figura 4.12-c pode-se observar também a presença de outras duas fases (ponto 2 e ponto 3) presentes no material infundido. Os resultados da microanálise química revelaram que uma das fases apresentou um elevada quantidade de cálcio (ponto 3), que pode corresponder a uma partícula de calcário que não foi fundida. A outra fase apresentou pequenas quantidades de cobre e ferro que poderiam ter como origem os teores de cobre e ferro presentes nas cinzas da incineração do lodo de cromo. Não obstante, nesta fase foi observada também a presença de estanho, elemento que não foi observado na composição das cinzas nem das matérias-primas utilizadas para preparação dos vidros, o que sugere que este material possa ser um corpo estranho proveniente das ferramentas utilizadas para cortar os vidros ou produto da contaminação acidental durante o armazenamento da amostra. Os resultados das microanálises das fases observadas são apresentados na Tabela 4.13.

Tabela 4.13 - Composição química por EDS dos vidros preparados.

\begin{tabular}{lcccccc}
\hline & \multicolumn{5}{c}{ Porcentagem em massa (\%) } \\
Elementos & Área 1 & Área 2 & Área 3 & Ponto 1 & Ponto 2 & Ponto 3 \\
\hline $\mathrm{Si}$ & 53,40 & 48,49 & 51,58 & 62,34 & 28,93 & 1,04 \\
$\mathrm{Al}$ & & & 2,62 & & 1,57 & \\
$\mathrm{Na}$ & 9,31 & 13,04 & 9,83 & 2,80 & 7,33 & 1,70 \\
$\mathrm{Ca}$ & 10,41 & 8,98 & 11,10 & 3,87 & 10,43 & 69,01 \\
$\mathrm{Fe}$ & & & & & 5,64 & \\
$\mathrm{Cu}$ & & & & & 26,68 & \\
$\mathrm{Sn}$ & & & & & 5,88 & \\
$\mathrm{O}$ & 26,88 & 29,50 & 24,88 & 30,99 & 13,54 & 28,25 \\
\hline Total & 100,00 & 100,01 & 100,01 & 100,00 & 100,00 & 100,00 \\
\hline
\end{tabular}

\subsubsection{Difração de raios $X$}

Com o intuito de verificar a natureza amorfa dos vidros estudados assim como identificar as fases cristalinas associadas à presença de infundidos e devitrificação foram determinados os padrões de DRX de algumas amostras. As amostras escolhidas para realizar as análises foram as amostras retiradas da parte superficial dos vidros que apresentaram a presença do material de coloração branca mostrado na Figura 4.9. Os padrões de difração de raios $X$ dos vidros analisados são apresentados na Figura 4.13. 
Figura 4.13 - Padrões de difração de raios $X$ dos vidros preparados.

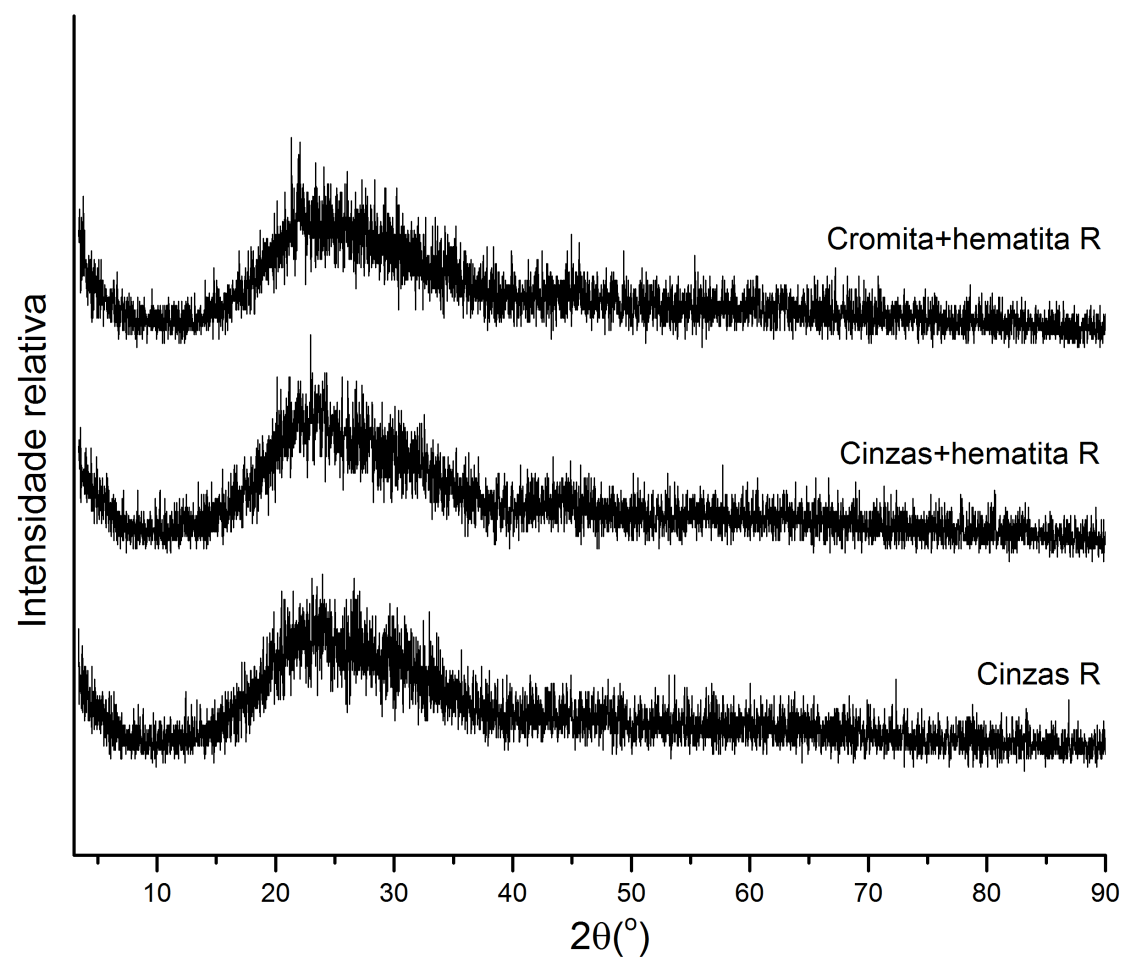

Os resultados da DRX mostraram que os vidros analisados apresentam a banda característica dos materiais vítreos sem a presença de picos evidentes. Estes resultados sugerem que os vidros preparados são totalmente amorfos. No entanto, baseados nos resultados da inspeção visual e microanálise química, que mostraram a presença de material infundido e possíveis zonas de devitrificação nas amostras, podemos inferir que a identificação dos picos associados a estas fases cristalina foi dificultada devido à baixa resolução dos padrões de raios $X$. Contudo, estes resultados mostram que os vidros preparados são predominantemente amorfos e que o procedimento de preparação das amostras adotado ofereceu condições para a formação preferencial de um estado vítreo.

\subsubsection{Determinação das coordenadas colorimétricas}

Na Figura 4.14 é apresentada a representação gráfica das coordenadas de cor no sistema CIE L*a*b*, obtidas por refletância, dos vidros experimentais e comerciais. Comparando as coordenadas de cor dos vidros experimentais preparados sob condições oxidantes e redutoras pode-se observar que as amostras preparadas sob condições oxidantes apresentam maiores valores da coordenada $+b^{*}$ (amarelo), provavelmente devido à maior concentração de íons $\mathrm{Fe}^{3+}$ que, como é sabido, conferem uma cor amarela pálida aos vidros sodo-cálcicos. 
Figura 4.14 - Coordenadas colorimétricas no sistema CIE L*a*b* obtidas por refletância dos vidros comerciais e vidros preparados sob condições oxidantes e redutoras.
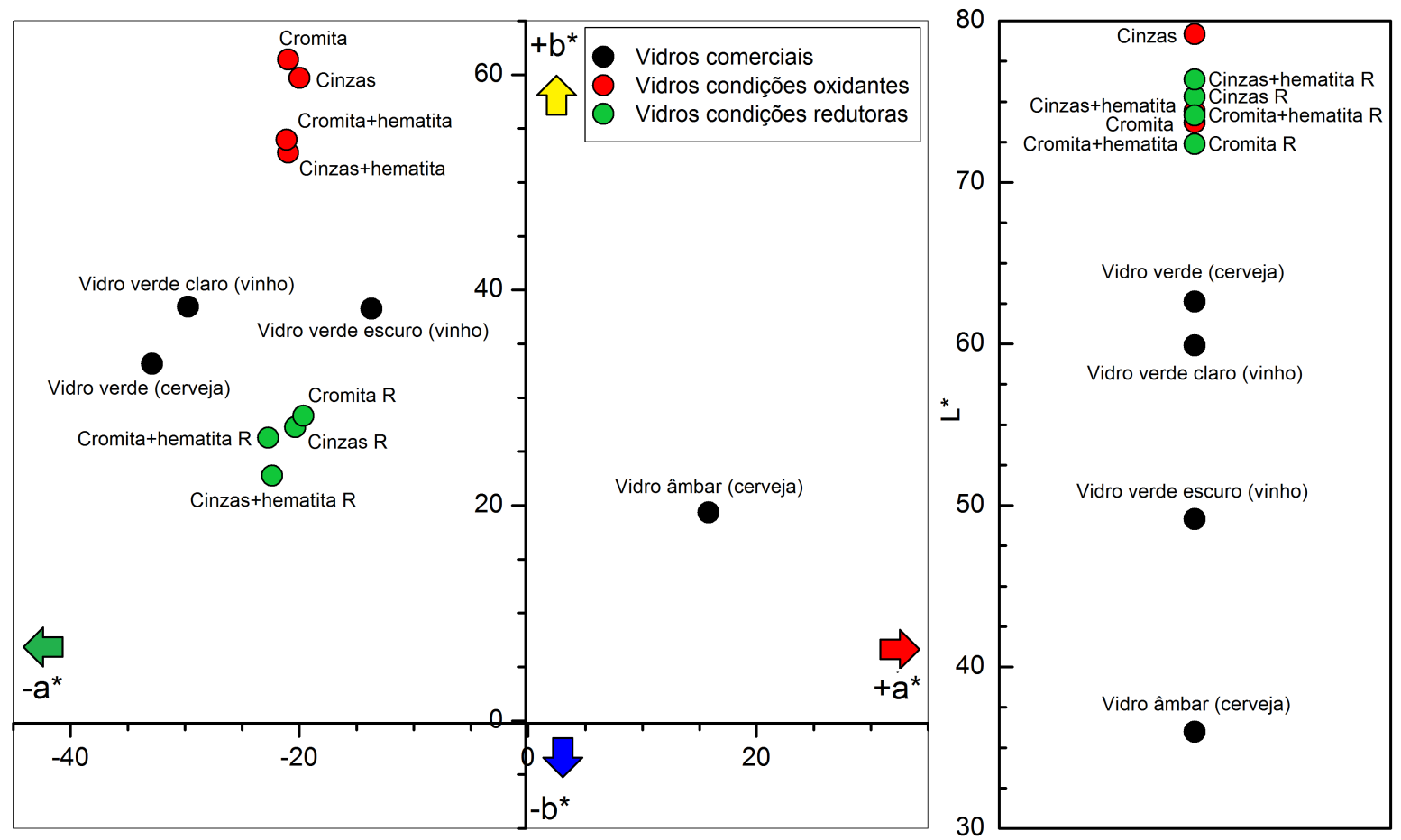

Na Figura 4.14 é possível observar que as amostras preparadas sob condições redutoras com adição de hematita, identificadas como "cromita+hematita R" e "cinzas+hematita R", apresentam valores da coordenada - $a^{*}$ (verde) levemente mais negativos do que os observados nas outras amostras preparadas sob condições redutoras e oxidantes. Estes valores podem estar relacionados à presença de uma maior concentração de íons $\mathrm{Fe}^{2+}$, que conferem uma cor verde escura aos vidros sodo-cálcicos, provavelmente causada pela adição de hematita e as condições redutoras.

Comparando a luminosidade $\left(\mathrm{L}^{*}\right)$ apresentada na Figura 4.14, dos vidros experimentais e dos vidros comerciais de coloração verde, podemos observar que os vidros comerciais apresentam menor luminosidade, provavelmente devido aos maiores teores de cromo e ferro presentes na sua composição (como pode ser verificado na Tabela 4.12), os quais estariam distribuídos preferencialmente na forma de íons $\mathrm{Cr}^{3+}$ e $\mathrm{Fe}^{2+}$ devido às condições redutoras nas quais esses vidros são fabricados. Pode-se observar também que a amostra de vidro comercial identificada como "vidro verde escuro (vinho)", apesar de possuir uma maior quantidade de cromo e ferro na sua composição, apresenta um valor da coordenada - $a^{*}$ (verde) menos negativo que os outros vidros comerciais provavelmente devido à formação do cromóforo $\mathrm{Fe}^{3+}-\mathrm{S}^{2-}$, que ocorre na presença de sulfatos e sob condições fortemente redutoras, que pode influenciar a cor do vidro conferindo-Ihe uma cor verde marrom (verde oliva). 
Na Figura 4.15 é apresentada a representação gráfica das coordenadas colorimétricas no sistema CIE L*a*b*, obtidas por transmitância, dos vidros comerciais e experimentais. Pode-se observar que os valores das coordenadas colorimétricas obtidos por transmitância são diferentes dos valores obtidos por refletância (Figura 4.14). Contudo, é possível observar que as coordenadas colorimétricas dos vidros experimentais obtidas por transmitância apresentam um comportamento similar às coordenadas obtidas por refletância. Por exemplo, as amostras preparadas sob condições oxidantes apresentam valores superiores da coordenada $+b$ (amarelo) aos das amostras preparadas sob condições redutoras.

Pode-se observar também que as amostras identificadas como "cromita+hematita R" e "cinzas+hematita R", de maneira similar ao que foi observado na Figura 4.14, apresentam valores da coordenada $-a^{*}$ (verde) mais negativos do que os observados nas outras amostras. Os valores das medições de cor no sistema CIE L*a* ${ }^{*}{ }^{\star}$ obtidas por transmitância e refletância dos vidros comerciais e vidros preparados no laboratório são apresentados na Tabela 4.14.

Figura 4.15 - Coordenadas colorimétricas no sistema CIE L*a*b* obtidas por transmitância dos vidros comerciais e vidros preparados sob condições oxidantes e redutoras.
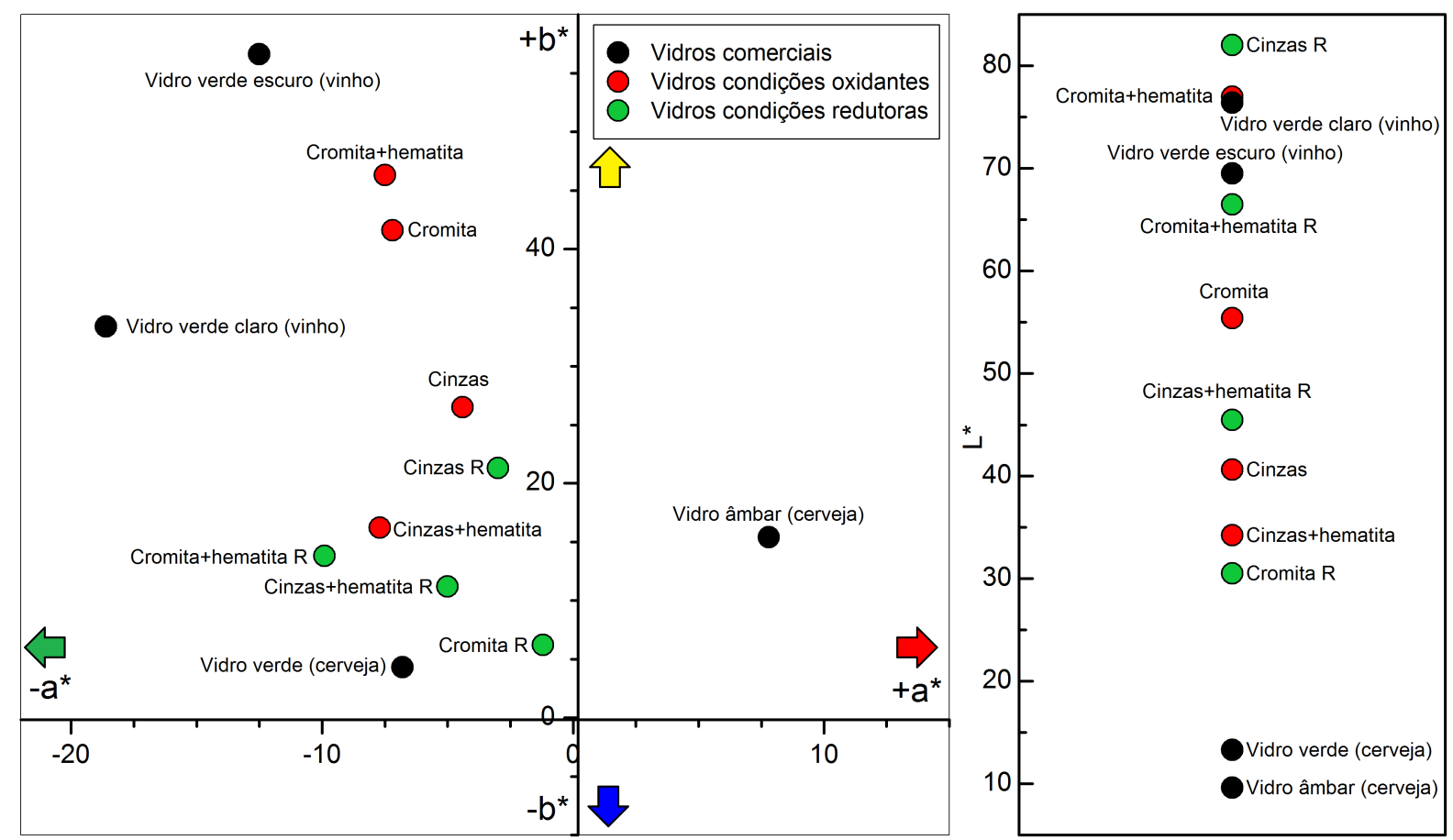
Tabela 4.14 - Coordenadas colorimétricas no sistema CIE L*a*b* obtidas por transmitância e refletância dos vidros comerciais e experimentais.

\begin{tabular}{lccc|ccc}
\hline \multicolumn{1}{c}{ Amostra } & \multicolumn{3}{c}{ Refletância } & \multicolumn{3}{c}{ Transmitância } \\
& $\mathrm{L}^{*}$ & $\mathrm{a}^{*}$ & $\mathrm{~b}^{*}$ & $\mathrm{~L}^{*}$ & $\mathrm{a}^{*}$ & $\mathrm{~b}^{*}$ \\
\hline Vidro verde (cerveja) & 62,62 & $-32,86$ & 33,14 & 13,3 & $-6,8$ & 4,3 \\
Vidro verde escuro (vinho) & 49,15 & $-13,68$ & 38,26 & 69,5 & $-12,5$ & 56,6 \\
Vidro verde claro (vinho) & 59,91 & $-29,73$ & 38,45 & 76,4 & $-18,6$ & 33,4 \\
Vidro âmbar (cerveja) & 35,99 & 15,80 & 19,36 & 9,6 & 7,8 & 15,4 \\
Cromita & 73,71 & $-20,95$ & 61,41 & 55,4 & $-7,2$ & 41,6 \\
Cinzas & 79,18 & $-19,96$ & 59,70 & 40,6 & $-4,4$ & 26,5 \\
Cromita+hematita & 72,38 & $-21,09$ & 53,97 & 77,0 & $-7,5$ & 46,3 \\
Cinzas+hematita & 74,40 & $-20,95$ & 52,75 & 34,2 & $-7,7$ & 16,2 \\
Cromita R & 72,38 & $-19,64$ & 28,31 & 30,5 & $-1,2$ & 6,2 \\
Cinzas R & 75,31 & $-20,36$ & 27,27 & 82 & $-3,0$ & 21,3 \\
Cromita+hematita R & 74,13 & $-22,70$ & 26,28 & 66,5 & $-9,9$ & 13,8 \\
Cinzas+hematita R & 76,36 & $-22,37$ & 22,77 & 45,5 & $-5,0$ & 11,2 \\
\hline
\end{tabular}

\subsubsection{Absorção óptica}

Conforme já foi mencionado anteriormente, para fins comparativos, foram analisados quatro vidros de embalagem comerciais (garrafas) utilizados para armazenar cervejas e vinhos. Adicionalmente foi incluída também uma amostra de um vidro de embalagem incolor, utilizado para armazenar refrigerante, como amostra de referência. As amostras dos vidros comerciais são apresentados na Figura 4.16.

Figura 4.16 - Amostras dos vidros de embalagem comerciais utilizados para armazenar refrigerantes, cervejas e vinhos.

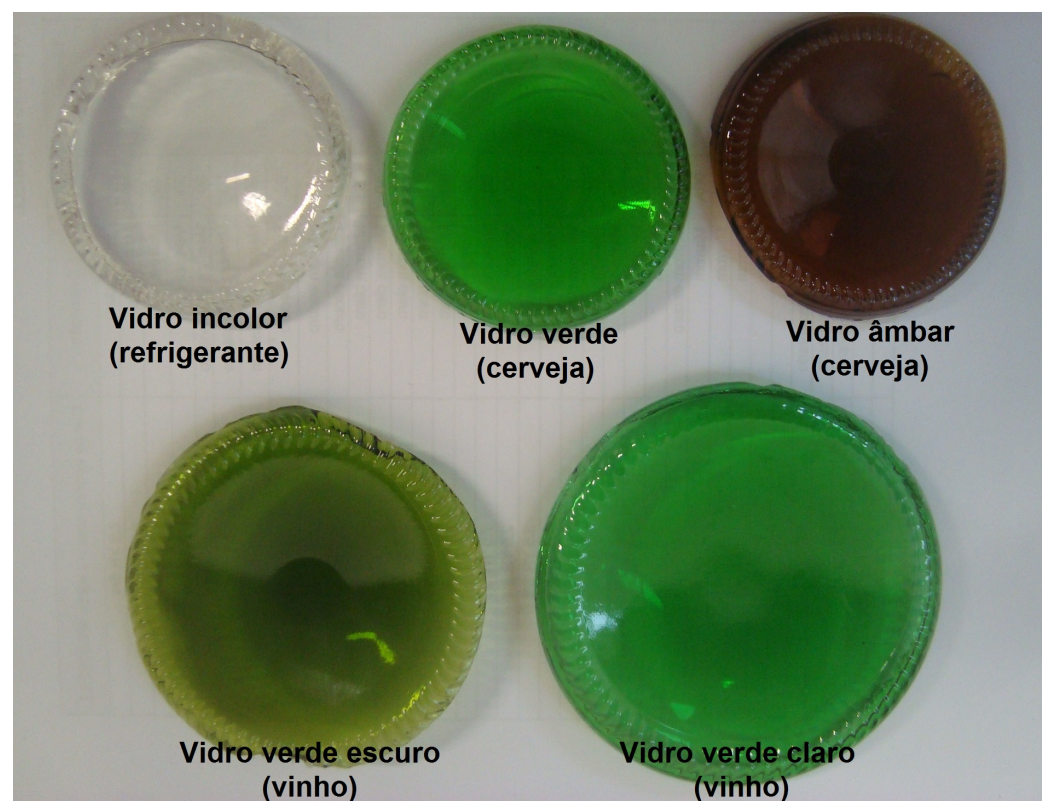


Na Figura 4.17 são apresentados os espectros dos coeficientes de absorção óptica dos vidros comerciais analisados. Na Figura 4.17-A pode-se observar que todos os vidros comerciais coloridos apresentam uma ampla banda de absorção centrada ao redor de 1100 nm, a qual corresponde à típica banda absorção do íon Fe ${ }^{2+}$ (YAMASHITA et al., 2008; DONALD; SWINK; SCHREIBER, 2006). Pode-se observar também que as intensidades da banda de absorção do $\mathrm{Fe}^{2+}$ aumentam com o conteúdo de ferro presente na composição dos vidros de coloração verde, apresentados na Tabela 4.12. Na Figura 4.17-A, é possível observar também a presença de uma forte banda de absorção centrada ao redor de 410 nm na amostra do vidro identificada como "vidro âmbar (cerveja)". Esta banda pode ser atribuída à presença do agente cromófero $\mathrm{Fe}^{3+}-\mathrm{S}^{2-}$, tipicamente localizado entre $410 \mathrm{e}$ 425 nm (BIRON; CHOPINET, 2013; KOMATSU et al., 1993), que produz uma absorção parcial do espectro visível e uma forte absorção da radiação ultravioleta.

Figura 4.17 - Curvas dos coeficientes de absorção óptica dos vidros de embalagem comerciais. (A) Bandas de absorção na região do ultravioleta, visível e infravermelho próximo, (B) Região do ultravioleta-visível.

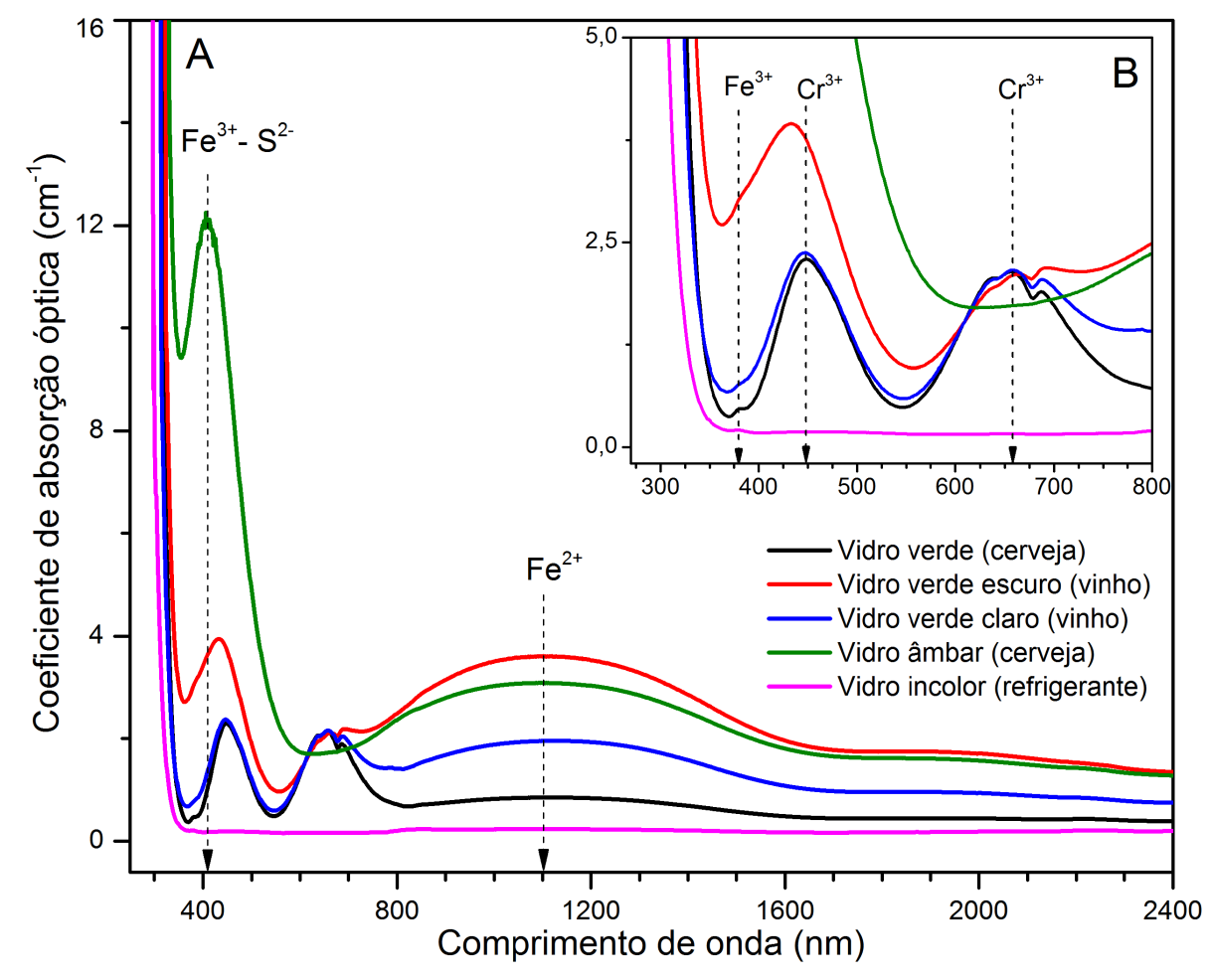

Comparando os espectros de absorção óptica da Figura 4.17-B é possível observar que a amostra de "vidro incolor (refrigerante)" absorve radiação UV somente desde comprimentos de onda menores, ou seja, absorve uma fração menor da radiação UV do que os vidros de coloração verde, que absorvem a radiação UV desde comprimentos de onda maiores. A absorção parcial da radiação UV dos vidros de coloração verde se deve ao efeito combinado dos íons $\mathrm{Fe}^{3+}$ e $\mathrm{Cr}^{3+}$. A presença do íon $\mathrm{Fe}^{3+}$ em vidros 
sodo-cálcicos produz bandas de absorção características em torno de 380, 420 e 435 $\mathrm{nm}$, que se estendem até comprimentos de onda ao redor de $450 \mathrm{~nm}$ (YAMASHITA et al., 2008; BAMFORD, 1978). Na Figura 4.17-B não foi possível observar detalhadamente estas bandas características provavelmente devido à baixa concentração do íon $\mathrm{Fe}^{3+}$ nos vidros assim como devido à sobreposição das bandas de absorção do íon $\mathrm{Cr}^{3+}$, centradas ao redor de 445 e 660 nm (ATKARSKAYA et al., 2011; MURATA et al., 1997; BAMFORD, 1978).

Na Figura 4.18 são apresentadas as curvas dos coeficientes de absorção óptica dos vidros preparados utilizando cromita e cinzas da incineração do lodo de cromo, ambos sem a adição de hematita, sob condições oxidantes (sem adição do agente redutor) e redutoras (adicionando o agente redutor). Pode-se observar que os vidros preparados sem a adição do agente redutor (coque de petróleo) apresentam uma forte banda de absorção centrada ao redor de $370 \mathrm{~nm}$, que corresponde à banda de absorção característica do $\mathrm{Cr}^{6+}$ (MURATA et al., 1997). Entretanto, a presença desta banda de absorção não foi observada nas amostras preparadas sob condições redutoras (identificadas com $\mathrm{R}$ no final no código da amostra). Estes resultados mostram a forte tendência dos íons cromo para formar $\mathrm{Cr}^{6+}$ na matriz vítrea sob as condições de temperatura e composição adotadas. Pode-se observar também que a intensidade da banda de absorção do $\mathrm{Cr}^{6+}$ na amostra preparada utilizando cromita é levemente menor à intensidade da amostra preparada utilizando as cinzas da incineração do lodo de cromo. Isto ocorre provavelmente devido ao maior teor de ferro presente na cromita, já que o $\mathrm{Fe}^{2+}$ sofre oxidação a $\mathrm{Fe}^{3+}$ mais facilmente que $\circ \mathrm{Cr}^{3+}$ a $\mathrm{Cr}^{6+}$, portanto uma maior concentração de íons ferro no vidro pode levar à formação preferencial de íons $\mathrm{Fe}^{3+}$ e a consequente diminuição na concentração de íons $\mathrm{Cr}^{6+}$ no vidro.

Na Figura 4.18 pode-se observar que a amostra preparada utilizando cinzas sob condições redutoras, identificada como "cinzas R", começa a absorver radiação UV somente desde comprimentos de onda menores do que os observados nas amostras preparadas usando cromita (amostra identificada como "cromita R"). Ou seja, a amostra "cinzas R" absorve menos radiação UV do que a amostra "cromita R". Isto ocorre provavelmente devido ao baixo teor de ferro presente na composição das cinzas $(1,4 \%$ de $\mathrm{Fe}_{2} \mathrm{O}_{3}$ ). Entretanto, a amostra preparada usando cromita sob condições redutoras, que apresenta uma quantidade considerável de ferro (17,93\% de $\left.\mathrm{Fe}_{2} \mathrm{O}_{3}\right)$, apresenta as bandas de absorção características do $\mathrm{Fe}^{3+}$ e portanto uma maior absorção de radiação UV. 
Figura 4.18 - Curvas dos coeficientes de absorção óptica dos vidros preparados utizando cromita e cinzas da incineração do lodo de cromo .

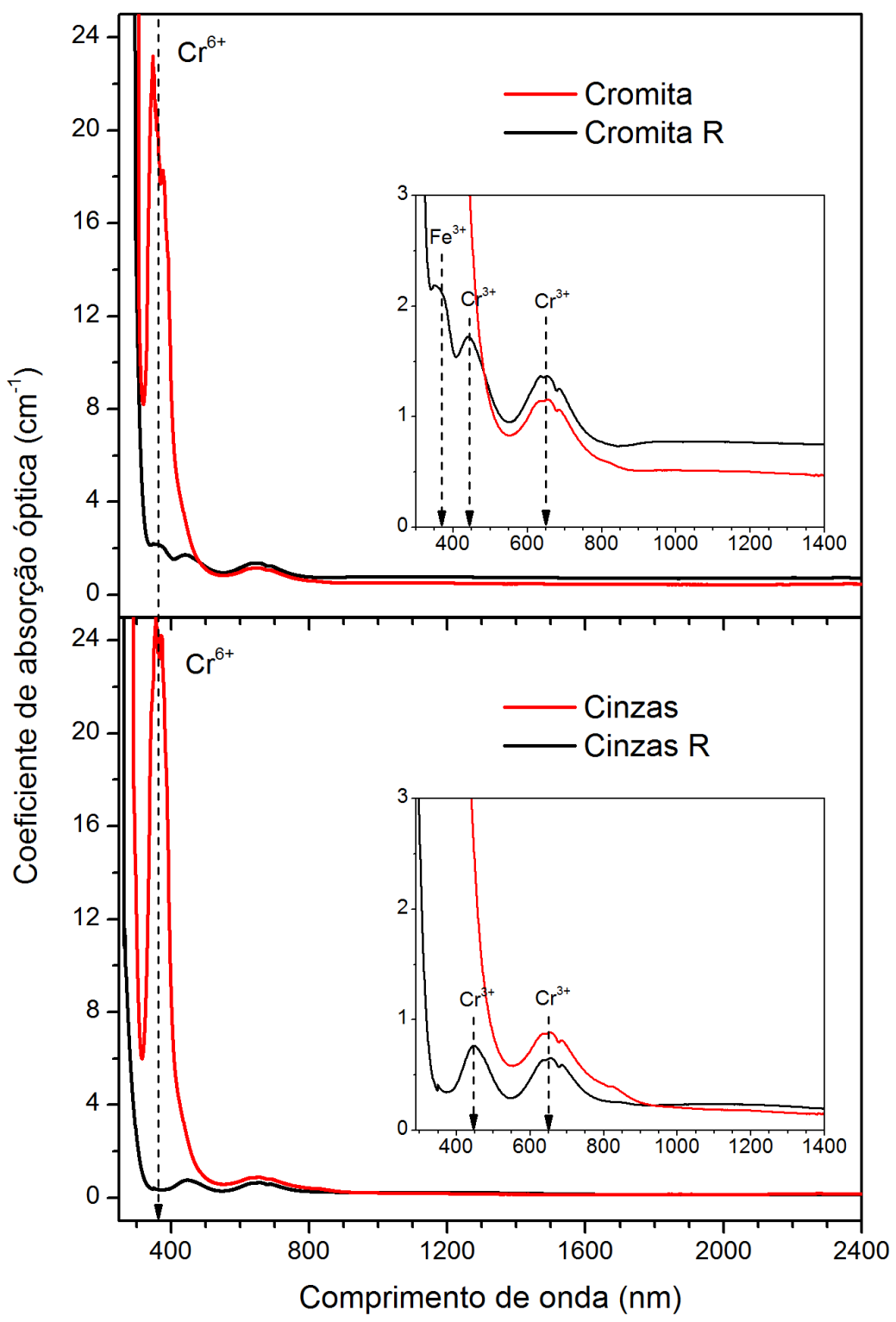

Na Figura 4.19 são apresentadas as curvas dos coeficientes de absorção óptica dos vidros preparados utilizando cromita e cinzas da incineração do lodo, ambos com a adição de hematita, sob condições oxidantes e redutoras. Pode-se observar que as amostras preparadas com a adição de hematita apresentam bandas de absorção de $\mathrm{Cr}^{6+}$ com intensidades levemente menores do que as observadas nas amostras sem adição de hematita (Figura 4.18). Isto ocorre provavelmente devido à maior concentração de ferro nas amostras com adição de hematita, visto que, como já foi comentado anteriormente, o $\mathrm{Fe}^{2+}$ é mais facilmente oxidado a $\mathrm{Fe}^{3+}$ que o $\mathrm{Cr}^{3+}$ a $\mathrm{Cr}^{6+}$. 
Figura 4.19 - Curvas dos coeficientes de absorção óptica dos vidros preparados usando cromita e cinzas da incineração de lodo de cromo, ambos com adição de hematita.

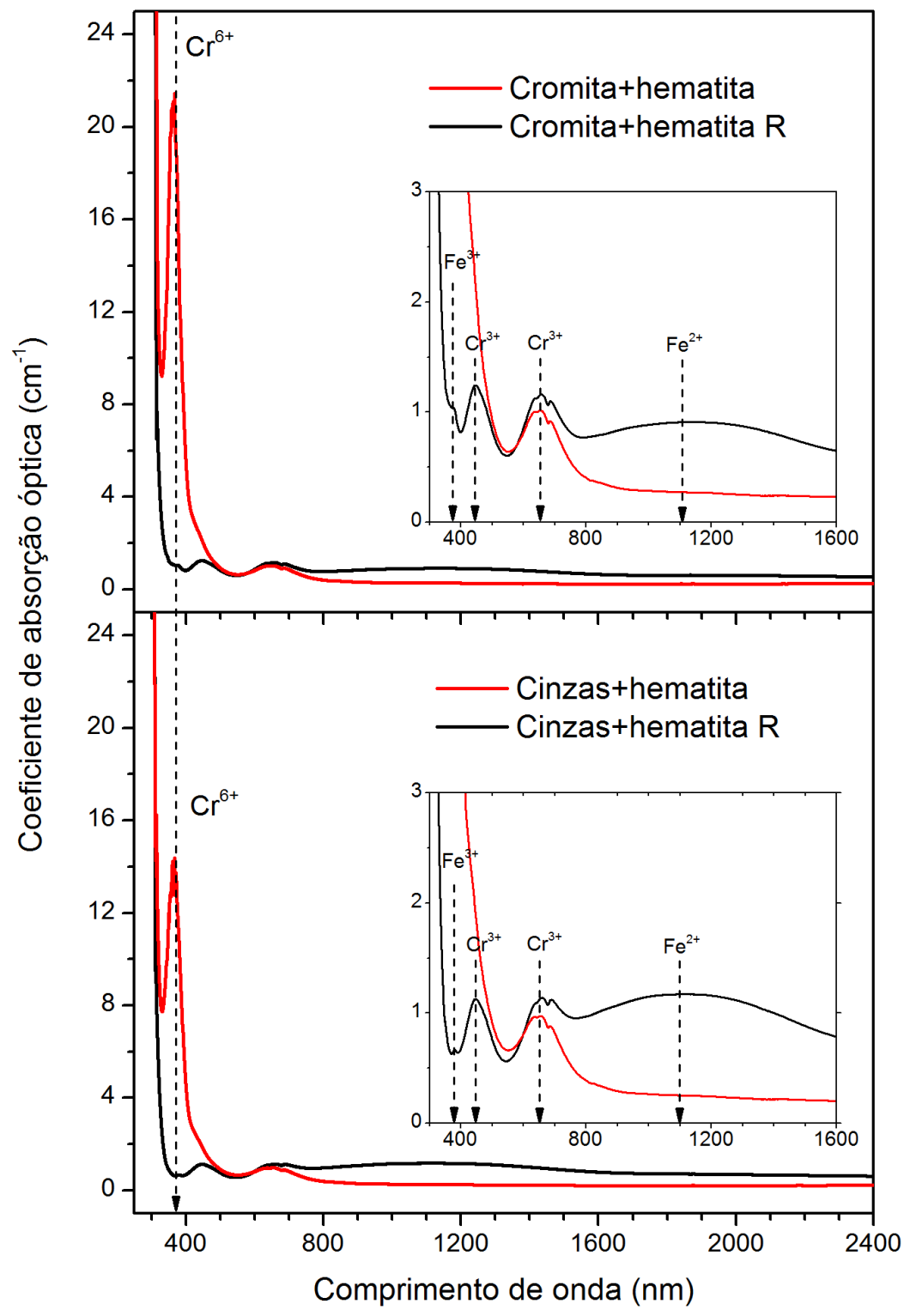

As amostras preparadas sob condições redutoras contendo hematita (Figura 4.19) não revelaram a presença da banda de absorção do $\mathrm{Cr}^{6+}$. Este resultado sugere que não há uma presença significativa de $\mathrm{Cr}^{6+}$ na composição do vidro, no entanto, devido a sua elevada toxicidade é recomendável utilizar outras técnicas complementares para determinar a concentração do $\mathrm{Cr}^{6+}$ no vidro. Lembrando que de acordo com as legislações europeias e dos Estados Unidos, o peso total de cádmio, mercúrio, chumbo e cromo hexavalente presente em componentes de embalagens e nas próprias embalagens não deve ultrapassar 100 partes por milhão (OTTAWAY, 2001; LEWIS, 2012). 
Na Figura 4.20 são comparadas as curvas dos coeficientes de absorção óptica dos vidros de embalagem comerciais de coloração verde e os vidros preparados utilizando cromita e cinzas da incineração de lodo de cromo, ambos com a adição de hematita. Pode-se observar que apesar de apresentar quantidades menores de ferro e cromo na sua composição, os vidros preparados no presente trabalho apresentam as mesmas bandas de absorção, com intensidades menores, que os vidros comerciais. Na Figura 4.20 é possível observar também que os vidros preparados usando cromita e cinzas apresentam bandas de absorção semelhantes no intervalo analisado. Estes resultados sugerem que, sob condições adequadas de formulação e fusão do vidro, é possível utilizar-se as cinzas ricas em cromo provenientes da incineração do resíduo estudado como uma fonte alternativa de cromo para a fabricação de vidros sodo-cálcicos coloridos.

Figura 4.20 - Curvas dos coeficientes de absorção óptica dos vidros de embalagem comerciais e dos vidros preparados usando cromita e cinzas com a adição de hematita.

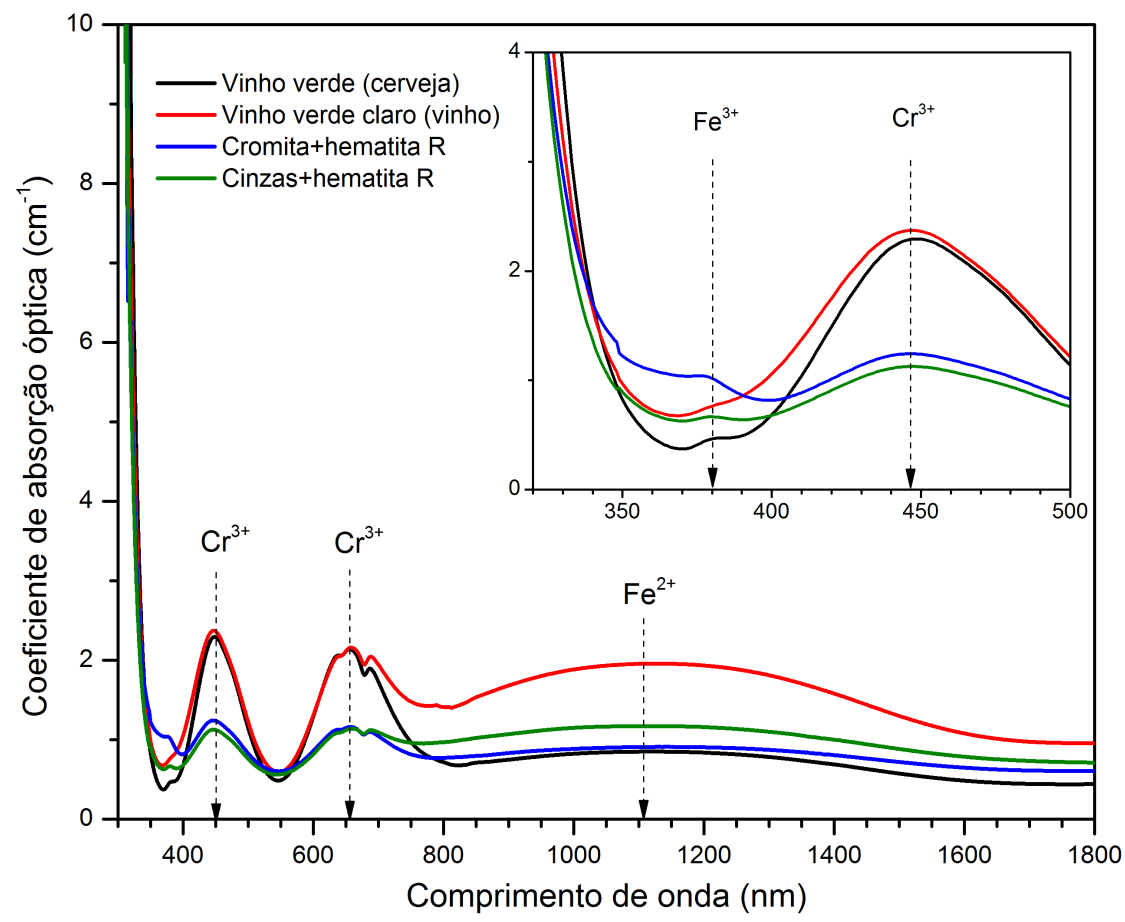




\section{Conclusões}

De acordo com os resultados obtidos neste trabalho, pode-se chegar às seguintes conclusões:

- O lodo de cromo estudado apresenta uma considerável quantidade de cromo em sua composição, aproximadamente $37 \%$ em massa (expressos em $\mathrm{Cr}_{2} \mathrm{O}_{3}$ ) de acordo com os resultados de FRX. A determinação das espécies de cromo por ICP-AES mostrou que o cromo presente neste resíduo é constituído somente por compostos de $\mathrm{Cr}(\mathrm{III})$. A presença majoritária de $\mathrm{Cr}_{2} \mathrm{O}_{3}$ foi confirmada pela análise das fases cristalinas por DRX.

- O valor de PCl apresentado pelo lodo de cromo, de 901,1 kcal/kg, está abaixo do valor necessário para auto-sustentar sua combustão (5000 kcal $/ \mathrm{kg})$ sem a necessidade do uso de um combustível adicional . Por conseguinte, é necessário considerar a co-incineração do lodo de cromo em conjunto com outros resíduos de características semelhantes, que apresentem valores de $\mathrm{PCl}$ superiores. Um resíduo de grande potencial para este propósito poderia são as aparas de couro curtido, material resultante da fabricação de artigos de couro, o qual apresentam valores de $\mathrm{PCl}$ por volta de $4000 \mathrm{kcal} / \mathrm{kg}$, segundo a literatura.

- As cinzas provenientes da incineração do lodo estudado apresentam um teor de cromo de aproximadamente $47 \%$ em massa (expressos em $\mathrm{Cr}_{2} \mathrm{O}_{3}$ ), valor não muito distante do teor de cromo observado na composição da cromita (cerca de $43 \%$ em massa de $\mathrm{Cr}_{2} \mathrm{O}_{3}$ ). Este resultado mostra o potencial deste resíduo para ser utilizado como fonte alternativa de cromo para a indústria de fabricação de vidros sodo-cálcicos. Além disso, mostra potencial também quando se consideram fontes de cromo alternativas à cromita nas indústrias química, metalúrgica e de refratários.

- A determinação das espécies de cromo revelou a presença de 0,5\% em massa de $\mathrm{Cr}(\mathrm{VI})$ nas cinzas da incineração do resíduo estudado, o que poderia levar à reavaliação das condições do processo de incineração adotado. Contudo, os vidros preparados utilizando as cinzas como fonte de cromo e sob condições similares às utilizadas na fabricação de vidros sodo-cálcicos comerciais (condições redutoras e 
adição de hematita) não apresentaram a banda de absorção óptica em torno de 270 $\mathrm{nm}$, característica do íon $\mathrm{Cr}^{6+}$.

- Todos os vidros preparados neste trabalho apresentaram uma cor verde homogênea em toda a espessura, textura superficial lisa e a presença ocasional de material infundido e bolhas visíveis. A inspeção visual por MEV, junto com a microanálise química por EDS revelaram também a presença de microbolhas, material infundido de dimensões microscópicas e zonas superficiais que sofreram devitrificação. Contudo, aparentemente não existe uma correlação entre a presença destes defeitos e o tipo de fonte de cromo (cromita ou cinzas) utilizada na fabricação das amostras.

- Os vidros preparados utilizando cromita e cinzas da incineração de lodo de cromo, ambos com a adição de hematita e do agente redutor (coque), apresentam bandas de absorção óptica semelhantes no intervalo analisado (200-3300 nm). Além disso, apesar de apresentar quantidades menores de ferro e cromo do que os vidros comerciais utilizados para armazenar vinhos e cervejas, esses vidros apresentam as bandas de absorção óptica nas mesmas posições, mas com intensidades menores.

- Estes resultados sugerem, portanto, que sob condições adequadas de incineração do lodo, bem como formulação e fusão do vidro, é possível utilizar-se as cinzas obtidas como fonte alternativa de cromo para a fabricação de vidros coloridos do sistema soda-cal-sílica. 


\section{Sugestões para trabalhos futuros}

- Coletar e caracterizar amostras de lodo de cromo de diferentes indústrias de curtume a fim de estabelecer a variabilidade deste resíduo.

- Estudar a influência da distribuição granulométrica das cinzas provenientes da incineração do lodo de cromo na presença de infundidos no vidro.

- Estudar a co-incineração do lodo de cromo com outros resíduos sólidos provenientes da indústria de curtume (aparas, serragem e pó de couro curtido).

- Estudar o uso de agentes redutores (carvão mineral, carvão vegetal, coque de petróleo e negro de fumo, entre outros) no processo de incineração do lodo de cromo e sua influência na formação de $\mathrm{Cr}(\mathrm{VI})$.

- Estudar a incineração do lodo de cromo em condições mais controladas, similares às observadas em incineradores de escala real.

- Utilizar técnicas complementares para determinar a concentração de $\mathrm{Cr}(\mathrm{VI})$ presente nos vidros preparados utilizando cinzas da incineração de lodo de cromo.

- Realizar fusões experimentais de vidros sodo-cálcicos contendo vários teores das cinzas provenientes da incineração de lodo de cromo, objetivando estudar a cristalização destes vidros.

- Realizar outras fusões experimentais de vidros sodo-cálcicos contendo maiores teores de ferro e cromo, determinando-se, por meio da espectroscopia de Mössbauer, as concentrações de $\mathrm{Fe}^{2+}$ e $\mathrm{Fe}^{3+}$, de maneira a avaliar-se a influência da relação $\mathrm{Fe}^{2+} / \mathrm{Fe}^{3+}$ no processo de oxidação-redução do cromo.

- Estudar o aproveitamento das cinzas da incineração do lodo de cromo em aplicações nas indústrias química, metalúrgica e de refratários. 


\section{ANEXO A - Fluxogramas dos processos produtivos dos tipos de curtume}


Figura A.1 - Diagrama do processo de beneficiamento de um curtume produtor de "wet-blue"

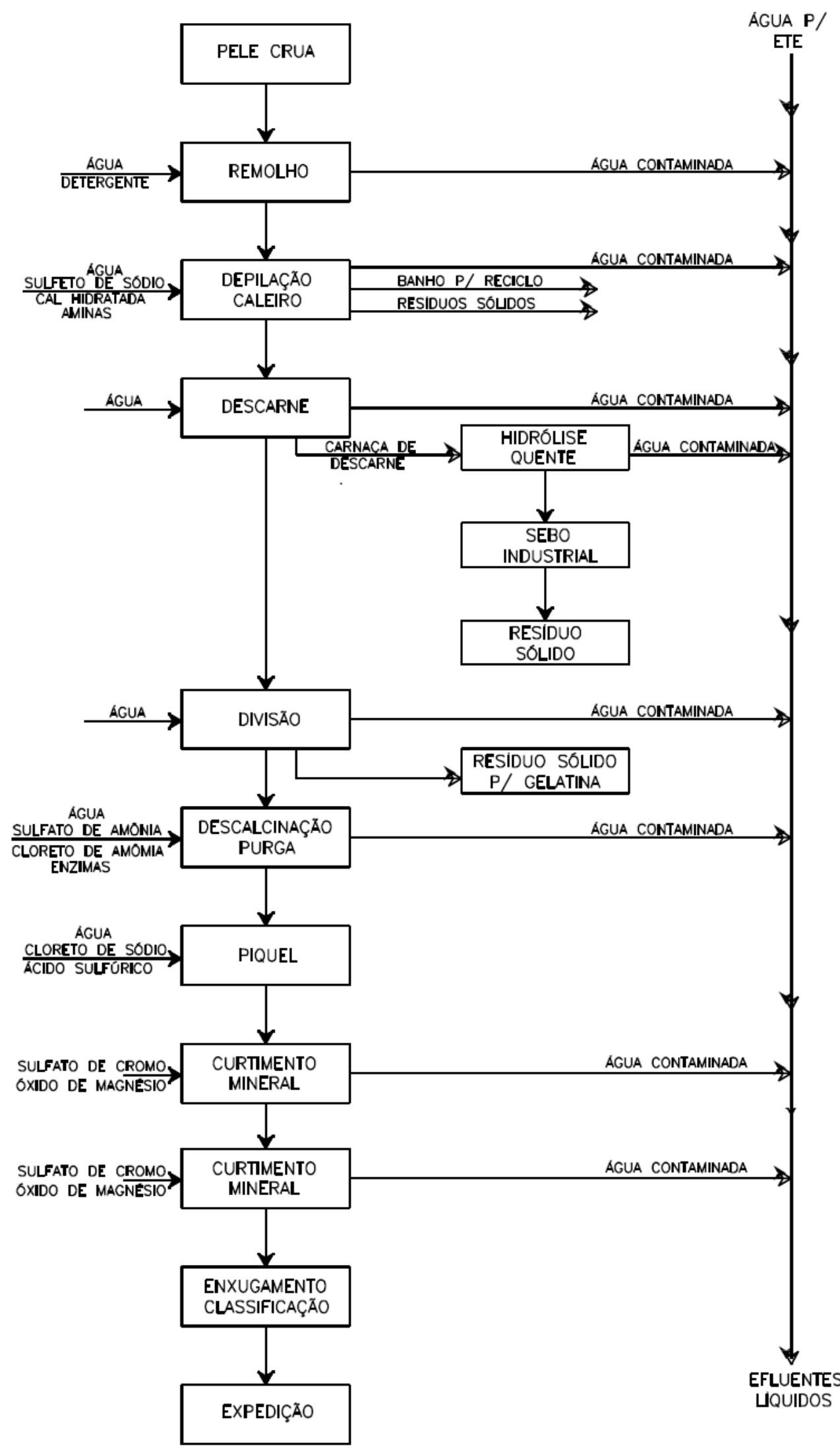

Fonte: fornecido pela AMCOA 
Figura A.2 - Diagrama do processo de beneficiamento de um curtume produtor de semi-acabado

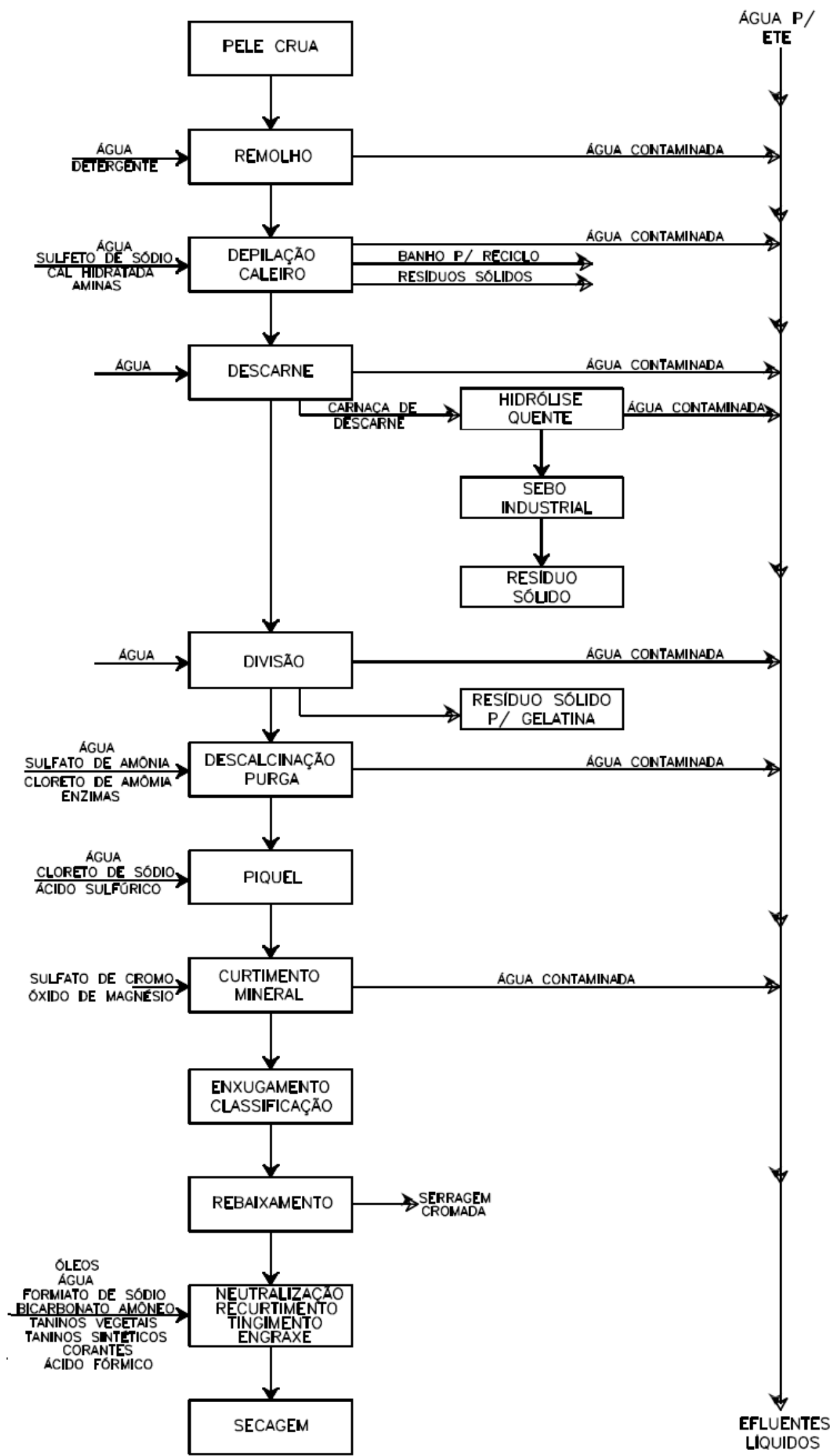

Fonte: fornecido pela AMCOA 
Figura A.3 - Diagrama do processo de beneficiamento de um curtume de processamento completo.

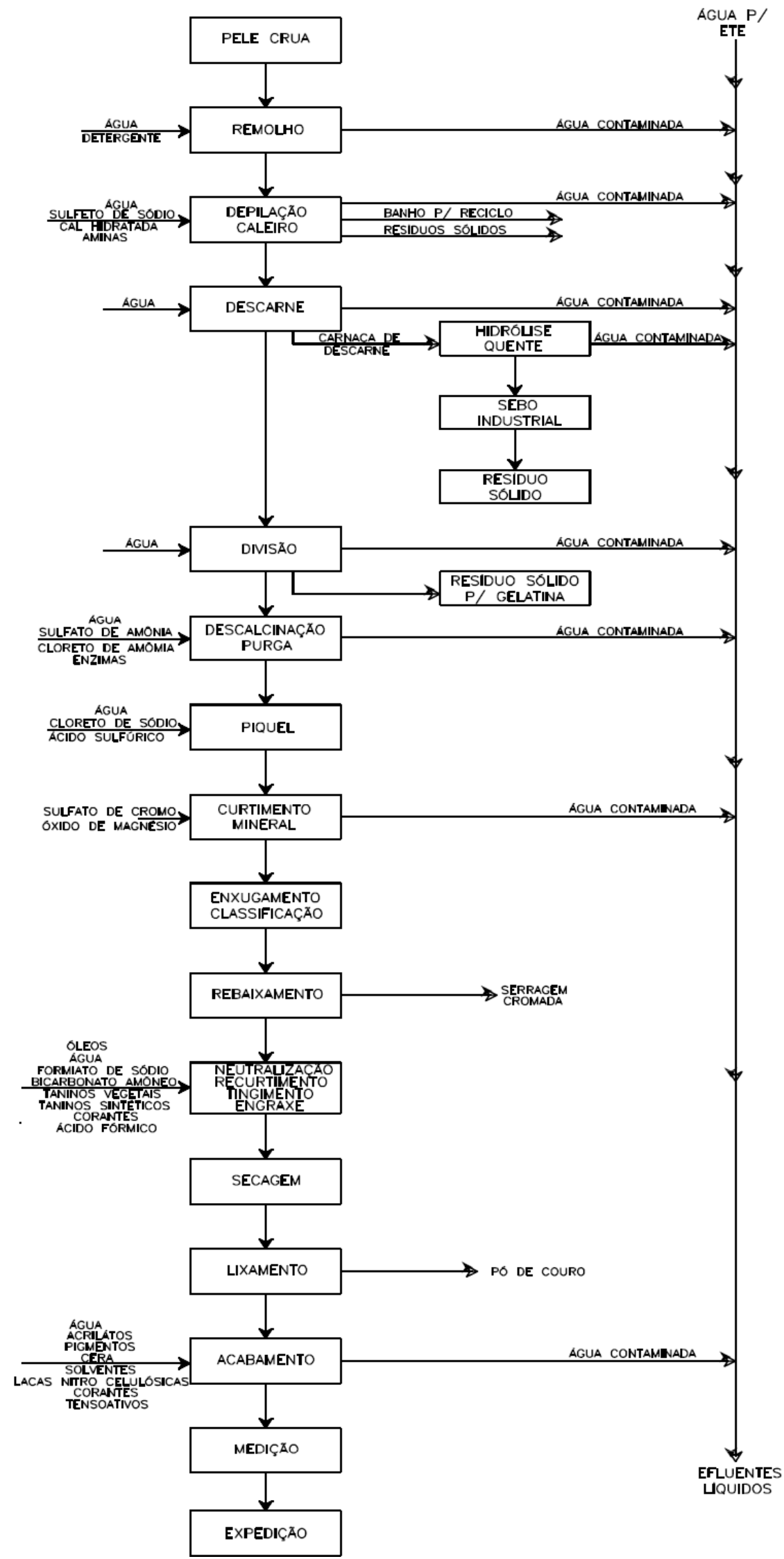

Fonte: fornecido pela AMCOA 
Figura A.4 - Diagrama do processo de beneficiamento de um curtume de acabamento a partir de "wet-blue"

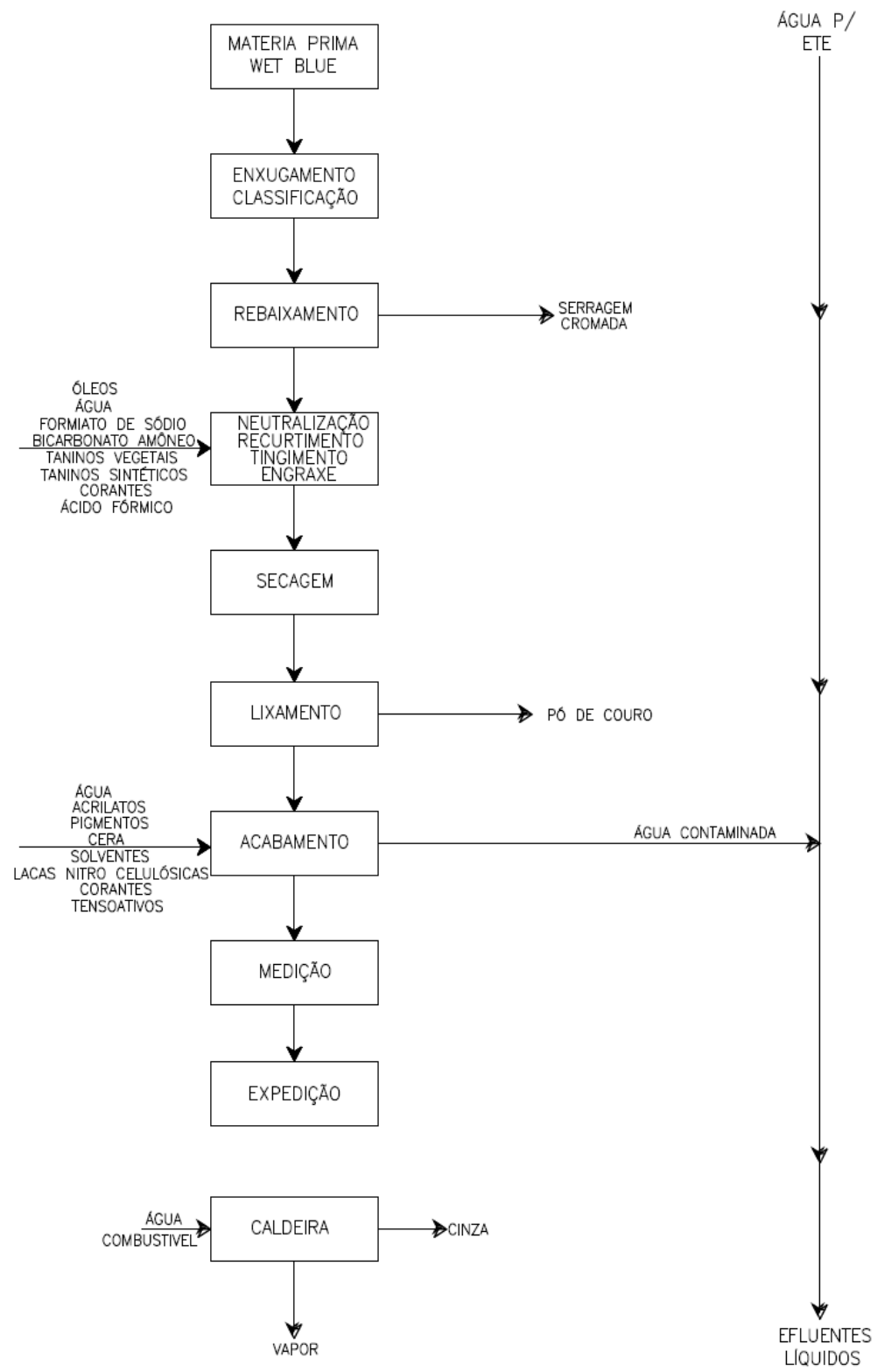

Fonte: fornecido pela AMCOA 
Figura A.5 - Diagrama do processo de beneficiamento de um curtume de acabamento a partir de semi-acabado.

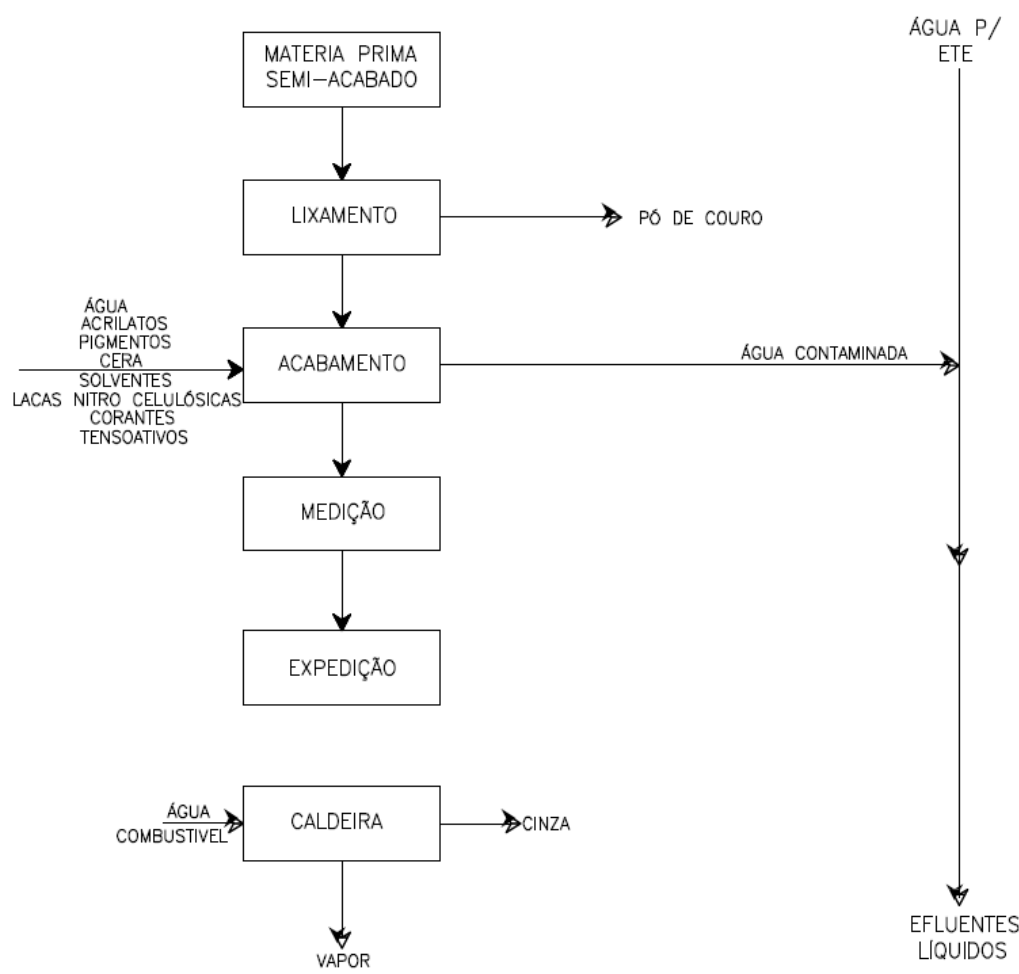

Fonte: fornecido pela AMCOA 


\section{Referências}

ABIVIDRO. Anuário ABIVIDRO. : Associação Técnica Brasileira das Indústrias Automáticas de Vidro, 2009.

ABREU, M.; TOFFOLI, S. Characterization of a chromium-rich tannery waste and its potential use in ceramics. Ceramics International, v. 35, p. 2225-2234, 2009.

ABREU, M. A. Reciclagem do resíduo de cromo da indústria do curtume como pigmentos cerâmicos. Tese (Doutorado) - Engenharia Metalúrgica e de Materiais, Universidade de São Paulo, 2006.

ALVES, C. R. R.; HECK, N. C.; SCHNEIDER, I. A. H. Utilização de cinzas da incineração de aparas de couro na produção em laboratórios de fecr-ac. Tecnologia em Metalurgia, Materiais e Mineração, v. 6, p. 61-65, 2009.

ALVES, O. L.; GIMENEZ, L. de F.; MAZALI, I. O. Vidros. Cadernos Temáticos de Química Nova na Escola, p. 13-24, 2001.

ALVES, V. C.; BARBOSA, A. S.; RENOFIO adilson. O poló coureiro-calçadista de franca-sp: características econômicas e ambientais. Revista INGEPRO, v. 1, p. 82-92, 2009.

ANANIAS, E. A.; PACCA, S. A. Tecnologias ambientais para curtumes e sua adequação como projetos do mecanismo de desenvolvimento limpo (mdl). In: 2nd International workshop advances in cleaner production. 2009.

ATKARSKAYA, A. B.; RASPOPOV, D. A.; CHARTII, P. V.; SHEMANIN, V. G. Heat tolerance of green glass conta. Glass and ceramics, v. 67, p. 307-311, 2011.

AXINTE, E. Glasses as engineering materials: A review. Materials and design, v. 32, p. 1717-1732, 2011.

BACARDIT, A.; MORERA, J. M.; OLLÉ, L.; BARTOLÍ, E.; BORRÀS, M. D. High chrome exhaustion in a non-float tanning process using a sulphonic aromatic acid. Chemosphere, v. 73 , p. 820-824, 2008.

BAMFORD, C. R. Colour Generation and Control in Glass. Amsterdam and New York: Elsevier, 1978. $224 \mathrm{p}$.

BASEGIO, T.; BERUTI, F.; BERNARDES, A.; BERGMANN, C. P. Environmental and technical aspects of the utilisation of tannery sludge as a raw material for clay products. Journal of the European Ceramic Society, v. 22, p. 2251-2259, 2002.

BASEGIO, T.; HAAS, C.; POKORNY, A.; BERNARDES, A.; BERGMANN, C. Production of materials with alumina and ashes from incineration of chromium tanned leather 
shavings: environmental and technical aspect. Journal of Hazardous Materials, B137, p. 1156-1164, 2006.

BASEGIO, T.; LEÃO, A. B.; BERNARDES, A.; BERGMANN, C. Vitrification: An alternative to minimize environmental impact caused bu leather industry wastes. Journal of Hazardous Materials, v. 165, p. 604-611, 2009.

BEST, A. W. M. W. de. Redox behaviour and fining of molten glass. : Technische Universiteit Eindhoven, 1994.

BIRON, I.; CHOPINET, M. Colouring, decoloring and opacifing of glass. In: JANSSENS, K. (Ed.). Modern methods for analysing archaeological and historical. : Wiley, 2013. p. 49-65.

BLACKMAN, W. C. Basic hazardous waste management. : CRC Press, 2001. 173 p.

BOURHIS, E. L. Glass Mechanics and Technology. : Wiley-VCH, 2007.

BRILL, T. B. Light:Its Interaction with Art and Antiquities. : Springer, 1980. 240 p.

CALLISTER, W. D. Fundamentals of Materials Science and Engineering. : John Wiley \& Sons, 2001. s-299 p.

CAMERON, D. H.; MCLAUGHLIN, G. D. The adsorption nature of chrome tanning. Journal of physical chemistry, v. 41, p. 961-974, 1937.

CARDARELLI, F. Materials handbook: a concise desktop reference. : Springer, 2008. $368 \mathrm{p}$.

CIAMBELLI, P.; SANNINO, D.; NAVIGLIO, B.; MANNA, A.; VAIANO, V.; CALVANESE, G.; VIETRI, G.; GALLO, S. Zeolite-chrome tanning: from laboratory to pilot scale. Studies in Surface Science and Catalysis, v. 155, p. 189-198, 2005.

CICB. Exportações brasileiras de couros e peles: Dezembro 2013. 2013. Disponível em: $<$ http://www.cicb.org.br/wp-content/uploads/2014/01/TOTAL-RED-DEZ13.pdf $>$. Acesso em: 2 de fevereiro de 2014.

CICB-APEXBRASIL. Brazilian leather magazine. 2013. Disponível em:

$<$ http://brazilianleather.com.br/wp-content/uploads/2013/04/Brazilian-Leather-BookMobile-ENG1.pdf>. Acesso em: 2 de fevereiro de 2014.

CIE. INTERNATIONAL COMMISSION ON ILLUMINATION. 19 mar. 2013. Disponível em: $<$ http://www.cie.co.at>. Acesso em: 22 de novembro de 2012.

COSTA, W. S. Avaliação da viabilidade técnica de coprocessamento de resíduos sólidos de curtumes contaminados com cromo em fornos de cimenteira. Dissertação (Mestrado) — Engenharia Civil, Universidade Federal de Goiás, 2009.

CULTRI, C. do N.; MANFRINATO, J. W. de S.; RENÓFIO, A. Resíduos sólidos do setor coureiro-calçadista e os fundamentos para a produção mais limpa. In: XIII SIMPÓSIO DE ENGENHARIA DE PRODUÇÃO - Bauru, SP, 6 a 8 de Novembro. 2006.

DANTAS, T. C.; OLIVEIRA, K.; NETO, A. D.; MOURA, M. The use of microemulsion to remove chromium from industrial sludge. Water research, v. 43, p. 1464-1470, 2009. 
DETTMER, A.; NUNES, K. G. P.; GUTTERRES, M.; MARCÍLIO, N. R. Obtaining sodium chromate from ash produced by thermal treatment of leather wastes. Chemical Engineering Journal, v. 160, p. 8-12, 2010.

DETTMER, A.; NUNES, K. G. P.; GUTTERRES, M.; MARCÍLIO, N. R. Production of basic chromium sulfate by using recovered chromium from ashes of thermally treated leather. Journal of Hazardous Materials, v. 176, p. 710-714, 2010.

DONALD, S. B.; SWINK, A. M.; SCHREIBER, H. D. High-iron ferric glass. Journal of no, v. 352, p. 539-543, 2006.

EPPLER, R. A. Understanding glazes. : American Ceramic Society, 2005. 326 p.

ERDEM, M. Chromium recovery from chrome shaving generated in tanning process. Journal of Hazardous Materials, B129, p. 143-146, 2006.

FABER, A. J. Optical properties and redox state of silicate glass melts. Comptes Rendus Chimie, v. 5, p. 705-712, 2002.

FERNANDES, H.; FERREIRA, J. Recycling of chromium-rich leather in porcelain tiles production. Journal od the European Ceramic Society, v. 27, p. 4657-4663, 2007.

FONSECA, J. C. L. da; MARCHI, M. R. R. de. Manual para gerenciamento de resíduos perigosos. 2009.

FORBES, R. J. Studies in ancient technology. Boston: Brill Academic Pub, 1997.

FUNDACENTRO. Apostila do curso sobre avaliação sa exposição ocupaccocupa dos trabalhadores no setor de fundição e medidas de ccontrole. : FUNDACENTRO Fundação Jorge Duprat Figueiredo de Segurança e Medicina do Trabalho, 2012.

FURNISS, D.; SEDDON, A. B. Principles and applications of thermal analysis. : Blackwell Publishing Ltd, 2008. $464 \mathrm{p}$.

GIUGLIANO, M.; PAGGI, A. Use of tannery sludge in brick production. Waste Management \& Research, v. 3, p. 361-368, 1985.

GODINHO, M. Gaseificação e combustão de resíduos sólidos da indústria calçadista. Tese (Doutorado) - Escola de Engenharia, Universidade Federal do Rio Grande do Sul, 2006.

GUERTIN, J. Toxicity and health effects of chromium. In: GUERTIN, J.; JACOBS, J. A.; AVAKIAN, C. P. (Ed.). Chromium (VI) handbook. : CRC Press, 2005. p. 215-234.

GUIMARÃES, D. L. Tratamento de lodo primário de estação de tratamento de efluentes e aplicação de protocolo de avaliação. Dissertação (Mestrado) - Engenharia Química, Universidade Federal de Campina Grande, 2008.

GUO, Z. ren; ZHANG, G.; FANG, J.; DOU, X. Enhanced chromium recovery from tanning wastewater. Journal of cleaner production, v. 14, p. 75-79, 2006.

GUPTA, P. Achieving production effectiveness and increasing business competitiveness through cleaner production: Leather sector profile. 2001. 
HERMES, E.; ORSSATTO, F.; HERMES, M. R.; BEAL, A.; JÚNIOR, C. A. G.; FRARE, L. M. Reciclagem dos banhos residuais de curtimento ao cromo, através da recuperação do mesmo por sedimentação. Revsita Brasileira de Produtos Agroindustriais, v. 11, p. 171-180, 2009.

HHS. Department of Health and Human services. Report on carcinogens of United States Department of Health and Human Services. 2011. 499 p.

HOLT, J. M. Ultrafast optical measurements of charge generation and transfer mechanisms of Pi-conjugated polymers for solar cell applications. : ProQuest, 2009.

HUNT, R.; POINTER, M. Measuring Colour. : Wiley, 2011.

JACKMAN, A. P.; POWELL, R. L. Hazardous Waste Treatment Technologies : Biological Treatment, Wet Air Oxidation, Chemical Fixation, Chemical Oxidation. : Noyes Publications, 1991.

JACOBS, J. A.; TESTA, S. M. Overview of chromium(vi) in the environment: background and history. In: GUERTIN, J.; JACOBS, J. A.; AVAKIAN, C. P. (Ed.). Chromium (VI) handbook. : CRC Press, 2005. p. 1-22.

KANAGARAJ, J.; BABU, N. C.; MANDAL, A. Recovery and reuse of chromium from chrome tanning waste water aiming towards zero discharge of pollution. Journal of Cleaner Production, v. 16, p. 1807-1813, 2008.

KELLER, W. O cromo nos resíduos sólidos de curtumes imobiliação em materiais cerâmicos. In: 190 Congresso Brasileiro de Engenharia Sanitária e Ambiental. 1997.

KOMATSU, T.; MOHRI, H.; NAKAGAWA, T.; MATUSITA, K. Optical absorption and raman scattering spectra of zn-s bonds in silicate glasses. Journal of materials science letters 12, v. 12, p. 1169-1171, 1993.

KUHL, C.; RUDOW, H.; WEYL, W. Sprechsaal keram. Glas. email, v. 71, p. 118, 1938.

LANGARD, S.; COSTA, M. Chromium. In: NORDBERG, G. F.; FOWLER, B. A.; NORDBERG, M.; FRIBERG, L. (Ed.). Handbook on the Toxicology of Metals. : Academic Press, 2007. p. 487-510.

LAURENTI, K. C. Avaliação da presença de gordura em tecido muscular e carnes usando DTA e TG. Dissertação (Mestrado) - Escola de engenharia de São Carlos - Faculdade de medicina de Riberão Preto -Instituto de química de São Carlos da Universidade de São Paulo, 2007.

LAZAU, R.; PACURARIU, C.; BECHERESCU, D.; IANOS, R. Ceramic pigments with chromium content from leather wastes. Journal od the European Ceramic Society, v. 27, p. 1899-1903, 2007.

LEWIS, H. Complying with regulations. : Springer, 2012.

LIMA, J. M. G. de. Perfil da mineração de cromo. 2009. Disponível em:

$<$ http://www.mme.gov.br/sgm/galerias/arquivos/plano_duo_decenal/a_mineracao_brasileira/P12_RT21_Perfil_da_Mineraxo_de_Cromo.pdf $>$. Acesso em: 5 de fevereiro de 2014. 
MANDAL, A. B.; GOVINDARAJU, K.; KANTHIMATHI, M.; RAMASWAMY, D. Physicochemical study on micelle formation of chromium-aluminium synthetic tanning materials in various environments and at various temperatures and its application to leather. Journal of the Society of Leather Technologists and Chemists, v. 67, p. 147-158, 1983.

MANRING, W.; DIKEN, G. A practical approach to evaluating redox phenomena involved in the melting-fining of soda-lime glasses. Journal of non-Crystalline Solids, v. 38-39, p. 813-818, 1980.

MANRING, W.; HOPKINS, R. Use of sulfate in glass. The Glass Industry, v. 39, p. 139-142, 1958.

MARCUS, R. T. Color for science, art and technology. : North Holland, 1998. 491 p.

MARTINS, C. M. Determinação das espécies de cromo nas cinzas da incineração de couro wet-blue em reatores de leito fixo e leito fluidizado. Dissertação (Mestrado) Engenharia Química, Universidade Federal do Rio Grande do Sul, 2001.

MATSUGO, S.; MIZUNO, M.; KONISHI, T. Free radical generating and scavenging compounds as a new type of drug. Current medicinal chemistry, v. 2, p. 763-790, 1995.

MEDES, D.; GIBIM, M. H.; TOFFOLI, S. M. Utilização de rejeitos de couro como fonte de óxido de cromo para a fabricação de vidros. In: 21 Encontro Técnico ABIVIDRO - São paulo, SP, 15 e 16 de setembro de 2011. 2011.

MÜER-SIMON, H. Advances in Fusion and Processing of Glass III. : Wiley, 2004. 299-313 p.

MILLER-IHLI, N. J. Chromium. In: STOEPPLER, M. (Ed.). Hazardous Metals in the Environment. : Elsevier Science, 1992. p. 373-404.

Harry N. Mills e John Jasinski. Olive-green glass compositions. 1982. U.S.Patent 4312953.

MÃNTYSALO, E.; MARJONIEMI, M.; KILPELÃINEN, M. Chrome tannage using high-intensity ultrasonic field. Ultrasonics Sonochemistry, v. 4, p. 141-144, 1997.

MORERA, J. M.; BARTOLÍ, E.; CHICO, R.; SOLé, C.; CABEZA, L. F. Minimization of the environmental impact of chrome tanning: a new process reusing the tanning floats. Journal of Cleaner Production, v. 19, p. 2128-2132, 2011.

MURATA, T.; TORISAKA, M.; TAKEBE, H.; MORINAGA, K. Compositional dependence of the valency state of $\mathrm{cr}$ ions in oxide glasses. Journal of non, v. 220, p. 139-146, 1997.

NASSAU, K. The Fifteen Causes of Color: The Physics and Chemistry of Color. : Wiley-Interscience, 1983. 504 p.

NASSAU, K. The fifteen causes of color: The physics and chemistry of color. Color research and applications, Wiley-Interscience, p. 1-26, 1987.

NASSAU, K. Reading on Color, Vol 2: The Science of Color. : The MIT Press, 1997. $497 \mathrm{p}$.

NASSAU, K. Color for science, art and technology. : North Holland, 1998. 490 p. 
NAVARRO, J. M. F. El vidrio. : Consejo Superior de Investigaciones Cientificas, 2003. $720 \mathrm{p}$.

NIESSEN, W. R. Combustion and Incineration Processes: Applications in Environmental Engineering. : CRC Press, 2002. 696 p.

OLIVEIRA, L. T. de. Incorporação de resíduo de curtume em artefactos cerâmicos - Uma alternativa para redução de passivo ambiental. Dissertação (Mestrado) - Saneamento Ambiental e Recursos Hídricos, Universidade Federal de Mato Grosso do Sul, 2008.

OLIVEIRA, P.; ROSA, M.; GONÇALVES, L.; TRANCOSO, M.; NOGUEIRA, C. Acid leaching of leather tanning sludges: Metals behaviour. Materials Science Forum, v. 587-588, p. 758-762, 2008.

OTTAWAY, P. B. EU Food Law: A Practical Guide. : Woodhead Publishing, 2001. 192 p.

PACHECO, J. W. F. Curtumes. : CETESB, 2005.

PAUL, A. Effect of thermal stabilization on redox equilibria and colours glass. Journal of non-Crystalline Solids, v. 71, p. 269-278, 1985.

PAUL, A. Oxidation-reduction equilibrium glass. Journal of Non-Crystalline Solids, $\mathrm{p}$. 354-362, 1990.

PEREIRA, S. V. Obtenção de cromato de sódio a partir das cinzas d eincineração de resíduos de couro do setor calçadista visando à produção de sulfato básico de cromo. Dissertação (Mestrado) - Engenharia Química, Universidade Federal do Rio Grande do Sul, 2006.

PICHTEL, J. Waste Management practices: Municipal, Hazardous, and Industrial. : CRC Press, 2005.

PINTO, C. A. Estudo da estabilização por solidificação de resíduos contendo metais pesados. Tese (Doutorado) - Engenharia Química, Universidade de São Paulo, 2005.

PINTO, C. A.; VALENZUELA-DÍAZ, F. R.; SANSALONE, J. J.; DWECK, J.; CARTLEDGE, F. K.; BÜCHLER, P. M. X-ray diffraction study of particulate tannery waste solidified in cement. Materials Science Forum, v. 530-531, p. 478-484, 2006.

PÜNTENER, D. A. G.; PEDRAZZI, D. R.; CLAUSEN, D. T.; HUNGER, D. K.; BAUER, D. W.; FILOSA, D. M.; ROSS, D. E. Industrial Dyes: Chemistry, Properties, Applications. : Wiley-VCH, 2004. 427 p.

QINGDONG-KE; MAX. Overview of chromium(iii) toxicology. In: VINCENT, J. (Ed.). The Nutritional Biochemistry of Chromium(III). : Elsevier, 2007. p. 257-263.

RAMOS, M. A. F. Cromo. Departamento Nacional de Produção Mineral (DNPM). 2010.

RAMOS, M. A. F. Cromo. Departamento Nacional de Produção Mineral (DNPM). 2013.

RAO, K. J. Structural Chemistry of Glasses. : Elsevier Science, 2002. 568 p.

RIBEIRO, D. V.; YUAN, S. Y.; MORELLI, M. R. Efeito da adição de serragem de couro tratada quimicamente nas propriedades do cimento portland. Quimica Nova, v. 34, p. 979-983, 2011. 
RODRIGUES, M.; AMADO, F.; XAVIER, J.; STREIT, K.; BERNARDES, A.; FERREIRA, J. Application of photoelectrochemicaleelectrodialysis treatment for the recovery and reuse of water from tannery effluents. Journal of Cleaner Production, v. 16, p. 605-611, 2008.

SAHIN, S.; SUMNU, S. G. Physical Properties of Foods. New York: Springer, 2006. 258 p.

SALMANG, H. Fundamentos fisico-quimicos de la fabricacion del vidrio. : Madrid Aguilar, 1962.

SAMPAIO, J. A.; ANDRADE, M. C. de; PAIVA, P. R. P. Cromita In: Rochas e Minerais Industriais. : Centro de Tecnologia Mineral Ministério da Ciência e Tecnologia CETEM, 2005.

SARAVANABHAVAN, S.; THANIKAIVELAN, P.; RAO, J. R.; NAIR, B. U.; RAMASAMI, T. Natural leathers from natural materials: progressing toward a new areana in leather processing. Environmental Science \& Technology, v. 38, p. 871-879, 2004.

SCHAEFFER, H. A. Scientific and technological challenges of industrial glass melting. Solid State Ionics, v. 105, p. 265-270, 1998.

SCHOLZ, W.; LUCAS, M. Techno-economic evaluation of membrane filtration for the recovery and re-use of tanning chemicals. Water Research, v. 37, p. 1859-1867, 2003.

SHAO, S.; SHI, K.; LI, Y.; JIANG, L.; MA, C. Mechanism of chrome-free tanning with tetra-hydroxynethyl phosphonium chloride. Chinese Journal of Chemical Engineering, v. 16 , p. $446-450,2008$.

SHELBY, J. E. Introduction to Glass Science and Technology. : Royal Society of Chemistry, 2005. $308 \mathrm{p}$.

SHEN, S.; TYAGI, R.; BLAIS, J.; SURAMPALLI, R. Bacterial leaching of metals from tannery sludge by indigenous sulphur-oxidizing bacteria - effect of sludge solids concentration. Journal of Environmental Engineering, v. 129, p. 513-519, 2003.

SHEVELL, S. K. The Science of Color. : Elsevier, 2003. 339 p.

SIMONI, J. A.; CHAGAS, A. Diagramas de ellingham e de van't hoff. algumas considerações. Quimica Nova, v. 30, p. 501-504, 2007.

SIMPSON, W.; MYERS, D. The redox number concepts and its use by the glass technologist. Glass technology, v. 19, p. 82-85, 1978.

SKOUROUMOUNIS, G. K.; KWIATKOWSKI, M.; SEFTON, M. A.; GAWEL, R.; WATERS, E. J. In situ measurement of white wine absorvance in clear and in coloured bottles using a modified laboratory spectrophotometer. Australian Journal of Grape and Wine Research, v. 9, p. 138-148, 2003.

SREERAM, K.; RAMASAMI, T. Sustaining tanning process through conservation, recovery and better utilization of chromium. Resources, Conservation and Recycling, v. 38, p. 185-212, 2003.

STREIT, K. F. Estudo da aplicação da ténica de eletrodiálise no tratamento de elfuentes de curtume. Dissertação (Mestrado) - Departamento de materiais, Universidade Federal do Rio Grande do Sul, 2006. 
SUNDAR, V. J.; RAO, J. R.; MURALIDHARAN, C. Cleaner chrome tanning - emerging options. Journal of cleaner production, v. 10, p. 69-74, 2002.

SUPARNO, O.; COVINGTON, A. D.; PHILLIPS, P. S.; EVANS, C. S. An innovative new application for waste phenolic compounds: Use of kraft lignin and naphthols in leather tanning. Resources, Conservation and Recycling, v. 45, p. 114-127, 2005.

SURESH, V.; KANTHIMATHI, M.; THANIKAIVELAN, P.; RAO, J. R.; NAIR, B. U. An improved product-process for cleaner chrome tanning in leather processing. Journal of Cleaner Production, v. 9, p. 483-491, 2001.

SWIFT, W. M.; PANEK, A. F.; SMITH, G. W.; VOGEL, G. J.; JONKE, A. A. Decomposition of calcium sulfate: a review of the literature. 1976.

TACHARD, A.; RIBEIRO, D.; MORELLI, M. Avaliação da resistência mecánica de argamassas de cimento portland contendo serragem de couro tratada em meio ácido. In: $17^{\circ}$ CBECIMat - Congresso Brasileiro de Engenharia e Ciência dos Materiais. 2006.

TAVARES, F. Centro de industrias de curtume do Brasil: Couro brasileiro ocupa posição de destaque no mercado internacional. 2011. Disponível em: <http://www.cicb.com.br. $>$. Acesso em: 09 de abril de 2011.

TILLEY, R. J. D. Defects in solids. : Wiley-Interscience, 2008.

VARSHNEYA, A. K. Fundamentals of inorgancic glasses. : Academic Press, 1993. 570 p.

VITALE, R. J.; CPC; MUSSOLINE, G. R.; RINEHIMER, K. A. Environmental monitoring of chromium in air, soil, and water. Regulatory toxicology and pharmacology, v. 26, p. S80-S85, 1997.

VOLF, M. B. Chemical approach to glass. : Elsevier Science Ltd, 1984. 594 p.

WENZEL, B. M. Redução Carbotérmica de cromo contido nas cinzas do tratamento térmico de resíduos de couro visando a obtainingtenção de liga ferrocromo e sulfato de cromo. Dissertação (Mestrado) - Engenharia Química, Universidade Federal do Rio Grande do Sul, 2008.

WENZEL, B. M.; MARCILIO, N. R.; GODINHO, M.; MASOTTI, L.; MARTINS, C. B. Iron and chromium sulfates from ferrochromium alloy for tanning. Chemical Engineering Journal, v. 165, p. 17-25, 2010.

YAMASHITA, M.; AKAI, T.; SAWA, R.; ABE, J.; MATSUMURA, M. Effect of preparation procedure on redox states of iron in soda-lime silicate glass. Journal of $n$, v. 354 , p. 4534-4538, 2008.

YUAN, S. Y. Estudo da influência da adição de serragem de couro tratada quimicamente nas características de argamassas de cimento portland. Dissertação (Mestrado) Engenharia de materiais, Universidade Federal de São Carlos, 2009.

ZACHARIASEN, W. H. The atomic arrangement in glass. Journal American Chemical Society, v. 54, p. 3841-3851, 1932. 
ZADRA-STONE, S.; BAGCHI, M.; PREUSS, H. G.; BAGCHI, D. Benefits of chromium(iii) complexes in animal and human health. In: VINCENT, J. (Ed.). The Nutritional Biochemistry of Chromium(III). : Elsevier, 2007. p. 183-206.

ZANOTTO, E. D. Surface crystallization kinetics in soda-lime-silica glasses. Journal of non-Crystalline Solids, v. 129, p. 183-190, 1991.

ZARZYCKI, J. Glasses and the vitreous state. : Cambridge University Press, 1991. 505 p.

ZHERNOVAYA, N.; ONISHCHUK, V.; DAVYDOGLU, B. Color control and redox balance monitoring in container glas. Glass and ceramics, v. 64, p. 111-114, 2007. 